\title{
Planktonic Foraminifera in the Sea of Okhotsk: Population and Stable Isotopic Analysis from a Sediment Trap
}

\author{
by
}

\section{Susan Elizabeth Alderman}

\author{
B.A. Mount Holyoke College
}

(1989)

Submitted in partial fulfillment of the

requirements for the degree of

MASTER OF SCIENCE

at the

\section{MASSACHUSETTS INSTITUTE OF TECHNOLOGY \\ and the}

\section{WOODS HOLE OCEANOGRAPHIC INSTITUTION}

May 1996

\section{(C) Susan Elizabeth Alderman 1996}

The author hereby grants to MIT and to WHOI permission to reproduce

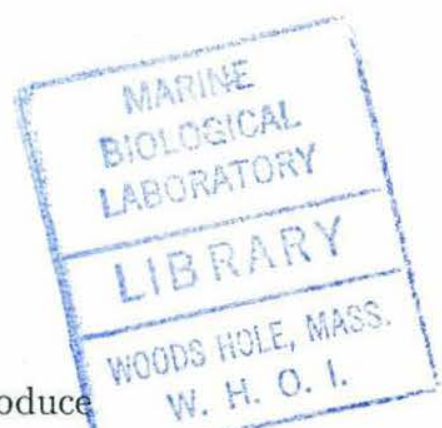
and to distribute copies of this thesis document in whole or in part.

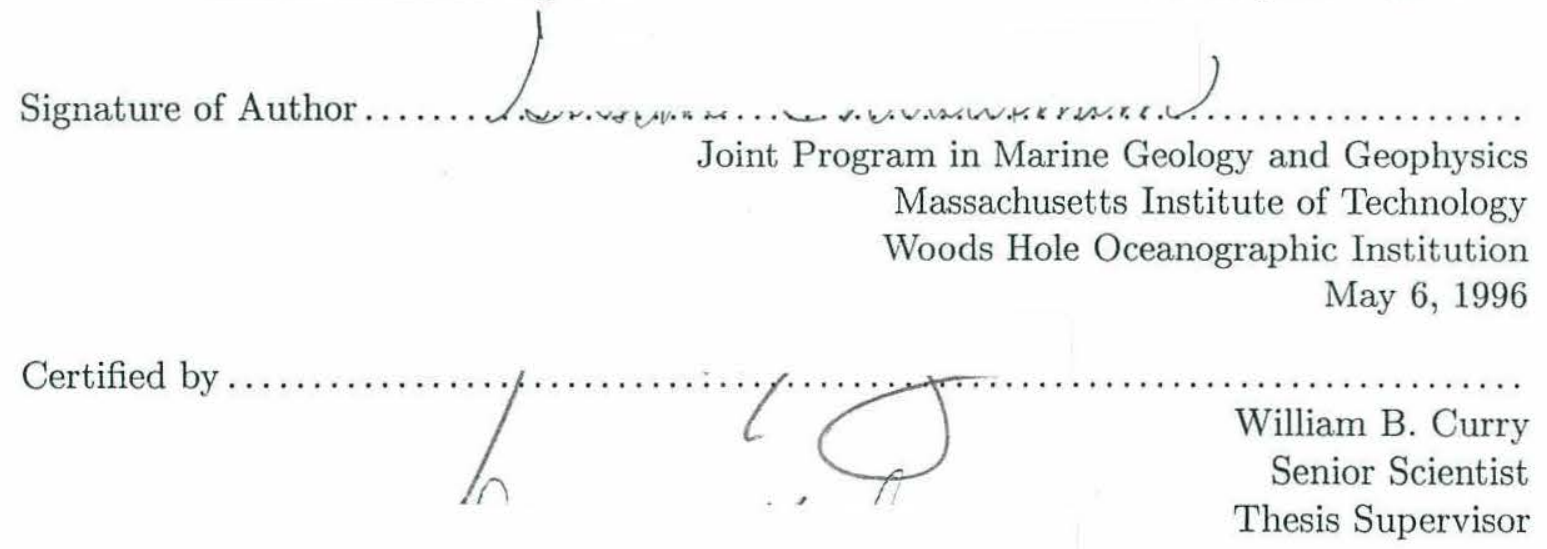

Accepted by

Deborah K. Smith Chair, Joint Committee for Marine Geology and Geophysics Massachusetts Institute of Technology Woods Hole Oceanographic Institution 


\title{
PLANKTONIC FORAMINIFERA IN THE SEA OF OKHOTSK: POPULATION AND STABLE ISOTOPIC ANALYSIS FROM A SEDIMENT TRAP
}

\author{
by
}

Susan Elizabeth Alderman
Submitted in partial fulfillment of the requirements for the degree of
Master of Science at the Massachusetts Institute of Technology and the Woods Hole Oceanographic Institution
May 6, 1996

\begin{abstract}
$\underline{\text { Abstract }}$
The relationship of planktonic foraminiferal populations and stable isotopes to synoptic sea surface temperatures (SST's) was examined in the Sea of Okhotsk, using sediment trap samples (trap deployed Aug. '90 - Aug. '91; $53^{\circ} 19^{\prime} \mathrm{N}, 149^{\circ} 50^{\prime} \mathrm{E}$ ) and AVHRR satellite sea surface temperature data. Synoptic SST's for the deployment ranged between -1.2 and $14.8^{\circ} \mathrm{C}$. Two species dominated total yearly foraminiferal flux: N. pachyderma (left) and G. bulloides, with $57 \%$ and $31 \%$ of yearly flux, respectively. Calcification depths

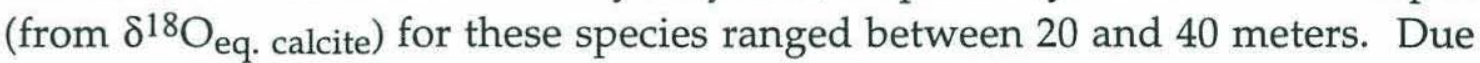
to the highly stratified water column in the Sea of Okhotsk, these foraminifera experienced temperatures much colder than SST, and use of standard paleotemperature proxies significantly underestimates SST. The average paleotemperatures calculated from both $\delta^{18} \mathrm{O}_{\text {pachy }}$ and $\delta^{18} \mathrm{O}$ bull were $5-6^{\circ} \mathrm{C}$ lower than average synoptic SST. Faunal indicators were consistent with this finding, with the $N$. pachyderma left-to-right coiling ratios $>98 \%$ for the entire trap deployment. These ratios would suggest maximum seasonal SST's no greater than $10^{\circ} \mathrm{C}$, nearly $5^{\circ} \mathrm{C}$ colder than the actual sea surface temperature maximum. The results from this study indicate that in highly stratified water columns, standard paleotemperature proxies may yield results as much as $5^{\circ} \mathrm{C}$ cooler than actual sea surface conditions.
\end{abstract}




\section{Acknowledgments}

Thanks are due to my advisor, Bill Curry, for providing the laboratory and facilities necessary for this study. Thanks also go to Dorinda Ostermann, who keeps that laboratory running smoothly. Sus Honjo provided the sediment trap samples which made this study possible. Thanks also to Steve Manganini, the keeper of those samples and innumerable data reports. The list of people with whom I have discussed the science in this thesis is long this is certainly an incomplete listing: Dick Norris, Delia Oppo, Pat Lohmann, Scott Lehman, Lloyd Keigwin, Lynne Talley, Frank Whitney, Howie Spero, Christina Ravelo, Dana Stuart, Kirsten Laarkamp, Eileen Kincaid, and Karen Kohfeld. Thanks especially to Sus Honjo, Lloyd Keigwin, Lynne Talley, C.S. Wong, and Karen Kohfeld, who have all let me use unpublished data. The Education Office folks, especially Ronni Schwartz, Abbie Alvin and Jake Pierson, have dealt with more of my paperwork than I dare to think about thanks! (Jake, we're going to miss you!) This research was supported by funds from the Woods Hole Oceanographic Education Office. Isotopic analyses were made under NSF grant DPP-9224288 (to David Schneider and William Curry), and ONR grant N00014-93-1-0709 (to William Curry). Sediment trap deployment was made possible by ONR grant N00014-89-J-1288 (to Susumu Honjo).

Thanks also, of course, go to all of my friends here in the Joint Program, who have helped keep me sane in moments of crisis. I know that I'm going to leave someone out of this list - it doesn't mean I'm not grateful, and I'm not thinking of you, it just means that my memory isn't perfect. The first hurdle was Generals: Kristina Faul (companion of many lunchtime walks), and Alice Shumate (supportive email maven) helped see me through this step. Many thanks to Dick Norris for his time, generosity, and simple humanity. He was always a breath of fresh air, not to mention a source of enchiladas! Thanks to Gwyneth Hufford for blueberry and peach jams. Sarah Zimmermann provided the facilities for jamming, and an invaluable MHC viewpoint on the world. Cedric provided many beautiful feathers (pretty boy boy boy!). Thanks to Rebecca Gardner for showing me the trail and the Zen. Maggie Rioux has been an excellent surrogate mom. Jay Austin and Jamie Pringle have been excellent housemates for these last few years, and have put 
up patiently with hungry cat noises (aka "howls"). John Buck has provided much Chinese food, and more reality checks than I can count.

Non-Joint Program people have been no less important in this whole process. Lois and Bill Bennett have been my Boston family for years. Brigid and George Alverson have also seen me through thick and thin. Tom Gentile and Steve Behrends have provided lots of good food and music, and "post-doc treats." I'll be able to return the favor soon! Al Werner continues to be a bottomless source of positive feedback, as he has been since 1989. Lois and Jay Tanzer have been excellent BSO companions, and have provided good Saturday evening discussion sessions.

This thesis is dedicated to Ericka Aldercat, who has always been glad to see me come home. 


\section{Table of Contents}

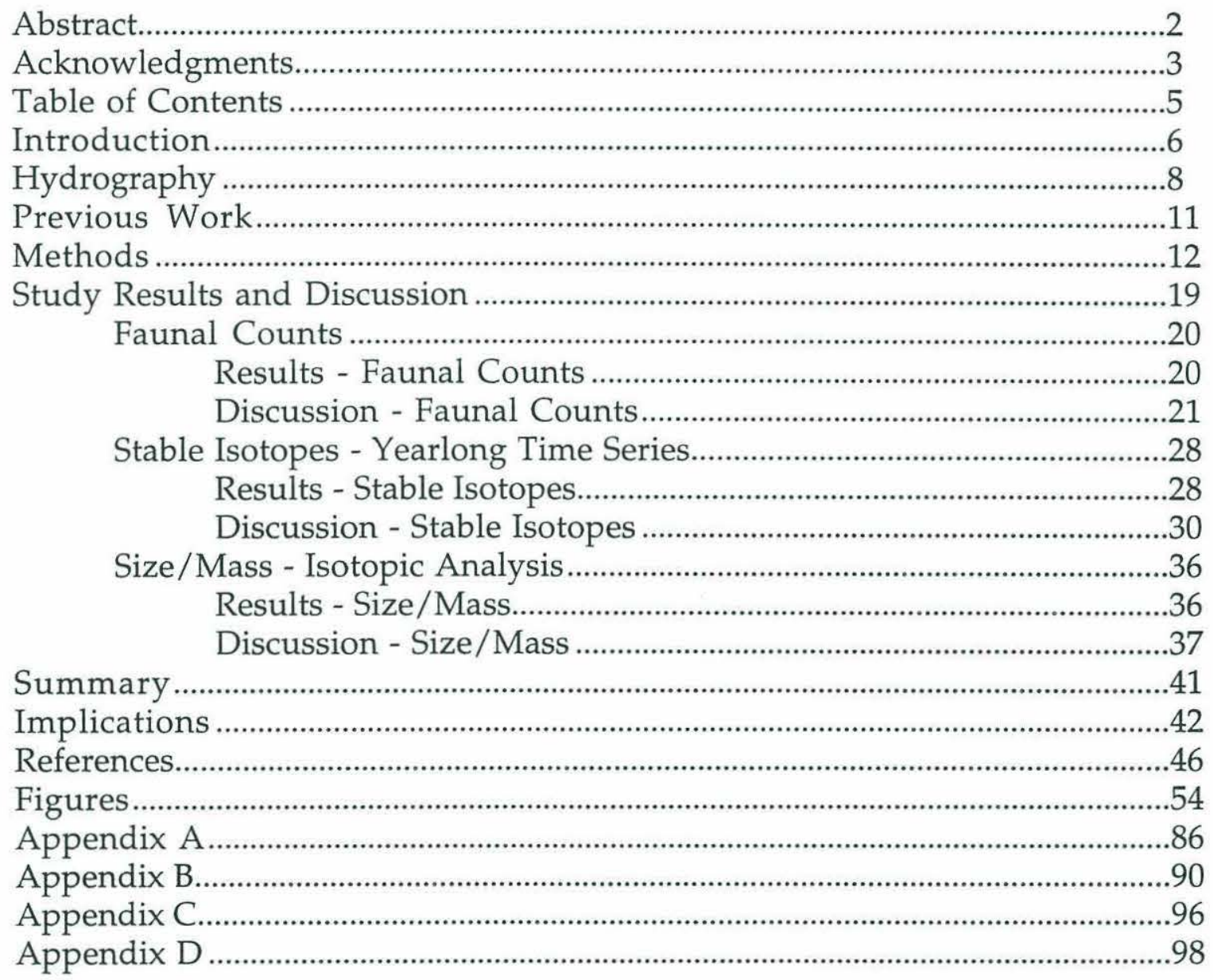




\section{Introduction}

One of the frequent assumptions of paleoceanographic studies using planktonic foraminifera has been that these organisms accurately reflect surface water conditions both now and in the past. Plankton net tow studies, however, have shown planktonic species living as deep as the thermocline (e.g. Fairbanks et al., 1982), suggesting that there may be inaccuracies in planktonic foraminiferal paleoceanographic proxies if the assumption is made that the foraminifera are living at the sea surface. As a modern-day analog for the glacial-age high latitude oceans, the Sea of Okhotsk enables not only ground truthing of these proxies, by direct comparison of paleoceanographic interpretation to real-time hydrography, but also yields insight into how much these proxies can tell us about the last glaciation.

This study uses planktonic foraminifera from a sediment trap deployed in the Sea of Okhotsk from August 1990 to August 1991 (Figure 1) (Honjo et al., 1995, in press) and synoptic sea surface temperatures from the Advanced Very High Resolution Radiometer (AVHRR) to compare planktonic foraminiferal paleoceanographic proxies to measured sea surface conditions. Detailed analysis has been made of the seasonality and population makeup of planktonic foraminiferal flux, and the seasonal and population variability of stable isotopes $\left(\delta^{18} \mathrm{O}\right.$ and $\delta^{13} \mathrm{C}$ ). Results from this study indicate that Globigerinoides bulloides and Neogloboquadrina pachyderma (left-coiling) calcify in $\delta^{18} \mathrm{O}$ equilibrium, between 30 and 40 meters water depth. In highly stratified locations like the Sea of Okhotsk, these calcification depths enable large populations of $\mathrm{N}$. pachyderma (l) to live in water $<10^{\circ} \mathrm{C}$ (less than $7^{\circ} \mathrm{C}$ from $\delta^{18} \mathrm{O}$ ), when sea surface temperatures are much higher. Faunal SST reconstructions using planktonic foraminiferal assemblages would underestimate SST by as much as $5^{\circ} \mathrm{C}$ in this location. 
The Sea of Okhotsk was chosen for this study on the basis of previous diatom and radiolarian work which has suggested that the Sea of Okhotsk is a modern day analog for glacial-age high latitude oceans. Sancetta and Silvestri (1986) found that the North Pacific diatom assemblage most common in the late Pleistocene most closely resembles the modern day assemblage in the central Sea of Okhotsk with an $\mathrm{r}^{2}>0.61$. Morley and Hays (1983) performed a similar study with radiolaria, finding high abundances of the cosmopolitan species Cycladophora davisiana (Ehrenberg) in the modern Sea of Okhotsk. This species is now found in low percentages $(<5 \%)$ from all oceans and all latitudes, except in the Sea of Okhotsk where modern abundances are typically $>20 \%$ of the total radiolarian population. During the late Pleistocene, this species dominated the total radiolarian population in high latitude regions in both hemispheres reaching abundance levels $>40 \%$.

Despite its intriguing similarity to the high latitude glacial ocean, there have been few planktonic foraminiferal studies performed in the Sea of Okhotsk. The two previous studies have examined planktonic foraminiferal assemblages from sediment cores (Kitazato, 1978; Lipps \& Warme, 1966). The deployment of a sediment trap mooring in the Sea of Okhotsk (Honjo et al., 1995, in press) gives the opportunity to examine the relationship of present day hydrography and planktonic foraminiferal populations.

The central Sea of Okhotsk is ideal for a sediment trap study of planktonic foraminifera. Productivity is high in the region of trap deployment, and extremely concentrated within the upper water column. Zenkevitch states that $90 \%$ of the biomass is concentrated within the upper 50 meters of the water column (Zenkevitch, 1963). Shuntov et al. (1993) give an average small zooplankton $(<1.5 \mathrm{~mm})$ biomass of $300-500 \mathrm{mg} / \mathrm{m}^{3}$ in the upper 50 meters, and Volkov and Chuchukalo (1985) report that total particulate 
matter biomass in the upper 100 meters ranges from $>2000 \mathrm{mg} / \mathrm{m}^{3}$ in spring to $500-1000 \mathrm{mg} / \mathrm{m}^{3}$ in summer. This depth concentration of biomass suggests a possible limit to the depths over which planktonic foraminifera may be expected to calcify, one of the most uncertain variables of any planktonic foraminiferal study. This biomass concentration is a result of the (primarily) temperature driven stratification within the upper water column (Zenkevitch, 1963); this strong thermocline (with a $\Delta \mathrm{T}$ as large as $16^{\circ} \mathrm{C}$ in the upper 50 meters) also results in a strong equilibrium calcite $\delta^{18} \mathrm{O}$ gradient, allowing precise depth habitat placement using the $\delta^{18} \mathrm{O}$ of foraminiferal calcite.

\section{Hydrography}

The basic circulation of the Sea of Okhotsk is a cyclonic gyre, made up of the northward flowing West Kamchatka current and the southward flowing East Sakhalin current (Talley \& Nagata, 1995). Details of published circulation schemes for the central region of the Okhotsk differ (see Talley \& Nagata, 1995); Talley (pers. commun. 1995) believes this may be due to significant eddy variability. Figure 2 shows a representative circulation scheme.

The three main inputs to the Sea of Okhotsk are, in order of decreasing rate: North Pacific waters entering through the Kuril Islands (mostly through Krusenshterna Strait), Sea of Japan water entering through Soya Strait, and fresh water from the Amur River (Talley \& Nagata, 1995). The North Pacific water comes from the southward flowing East Kamchatka current, part of which enters the Sea of Okhotsk and becomes the northward flowing West Kamchatka current (Yasuoka, 1967; Yasuoka, 1968). Transport of this North Pacific inflow has not been measured, but mass balance calculations for the 
Okhotsk indicate transport between 3-9 Sv (Talley \& Nagata, 1995). Salinity of this inflow varies from $32.8 \%$ in summer to $33.0 \%$ in winter at the surface and from 33.1 to 33.4 at 100 meters; temperature varies from $0^{\circ}$ to $9^{\circ} \mathrm{C}$ at the surface to $2.5^{\circ}$ to $0^{\circ} \mathrm{C}$ at 100 meters. Water from the Sea of Japan enters through the narrow, shallow Sôya Strait (42 km wide, sill depth 55 meters) as the Sôya Current. This current is seasonal, transporting 1Sv of warm salty water $\left(7-20^{\circ} \mathrm{C}, 33.6-34.3 \%\right.$ ) into the Sea of Okhotsk from June through November, and virtually disappearing during winter months (Takizawa, 1982). After entering the Okhotsk, the Sôya splits; two branches flow directly into the Pacific (through Nemoro and Kunashiri Straits, northeast of Hokkaido). The majority of the Sôya, however, flows along the Kuril Islands, turning northeast at Etorofu Island $\left(45^{\circ} \mathrm{N}, 147-149^{\circ} \mathrm{E}\right)$ and mixing with surrounding waters around $46^{\circ} \mathrm{N}, 146-147^{\circ} \mathrm{E}$ (Takizawa, 1982). The Amur River does not represent a significant inflow of water; estimates of discharge range between 315 and $600 \mathrm{~km}^{3} / \mathrm{yr}$ (Yang \& Honjo, in press). This water acts chiefly to freshen the surface waters of the Sea of Okhotsk in spring and summer.

Water flows out from the Sea of Okhotsk chiefly through Bussol' Strait. Transport estimates range from 4-12 Sv. This water joins waters flowing along the Kuril Island (possibly of E. Kamchatkan current origin) to become the cold Oyashio current (Talley \& Nagata, 1995).

The Sea of Okhotsk is the southernmost location of sea ice formation in the northern hemisphere. Coastal ice forms first in mid-November in Shelikof Bay, with freezing continuing counter-clockwise around the northern shelves. By the beginning of January, the western third of the sea is ice-covered, and by the end of January the east, west and north coasts have at least slight ice coverage (Parkinson \& Gratz, 1983). The ice edge then moves into the central Okhotsk, advancing towards the southeast outwards from the 
shelf. November and December is the time of maximum ice growth; ice edge retreat occurs during March and April (Cavalieri \& Parkinson, 1987). Retreat occurs basically in the reverse sequence, with the last coastal ice disappearing in June (Parkinson \& Gratz, 1983).

Sea of Okhotsk water column structure can be described generally as three layers: surface water (0-50 meters), the dichothermal layer (50-150 meters), and intermediate/deep waters ( $>150$ meters) (Figure 3 ). This structure is stable throughout the majority of the Sea of Okhotsk, with deeper mixing occurring only in the region of Kasheverova Bank (Talley \& Nagata, 1995). This stability and the thinness of the surface water layer leads to a high degree of seasonality within the upper water column. AHVRR measured sea surface temperatures (SST) for the region of the trap deployment data during the year August 1990-August 1991 ranged between $-1.2^{\circ}$ and $14.8^{\circ} \mathrm{C}$ (Figure 4). Temperatures on the northern shelf regions typically show larger temperature variability, with sea surface temperature decreasing to $-1.8^{\circ} \mathrm{C}$ during sea ice formation. In the region of North Pacific inflow the seasonal temperature range is lower, ranging from $\sim 1^{\circ} \mathrm{C}$ to $4^{\circ} \mathrm{C}$ (Kitani, 1973). Surface salinities vary seasonally, with lowest salinities in summer due to the influence of sea ice melt and/or river inflow (Kitani, 1973). Yakunin (1993) reports summer (July) salinities around 32.5\%, and winter salinities between $33.0 \%$ and $33.5 \%$. Kitani (1973) gives a slightly different range, with summer salinities $<32.8 \%$, and winter salinities ranging between $32.7 \%$ and $33.2 \%$.

The dichothermal layer (50-100 meters) is a low temperature layer that persists year-round in the Sea of Okhotsk. This layer is believed to be the remnant of the winter mixed layer (Kitani, 1973; Yang \& Honjo, in press), and has temperatures ranging from $-1.7^{\circ} \mathrm{C}$ in the Northern Okhotsk Sea and east of Sakhalin to $2.0^{\circ} \mathrm{C}$ along the northern Kuril Islands (Kitani, 1973). Salinity 
of this layer is around $33.0 \%$ (Kitani, 1973). Temperature and salinity of this layer vary somewhat from year to year, on the order of $1.0^{\circ} \mathrm{C}$ and $0.2 \%$ respectively (Dodimead et al., 1963). Intermediate and deep waters in the Sea of Okhotsk are of Pacific origin, with temperatures around $2.0^{\circ}-2.5^{\circ} \mathrm{C}$, and salinities around 34.3\%o (Yasuoka, 1967; Yasuoka, 1968).

\section{Previous Work}

There have been few previous planktonic foraminiferal studies from the Sea of Okhotsk. What work has been done suggests that the fauna is a modified North Pacific, sub-Arctic assemblage. Using plankton tow data, Bradshaw (1959) defines a Pacific Ocean sub-Arctic fauna as Globigerina pachyderma (Neogloboquadrina pachyderma), Globigerinoides cf. minuta (G. uvula), Globigerina quinqueloba, G. bulloides, G. eggeri (N. dutertrei), with occasional Globigerinita glutinata.

The most comprehensive Sea of Okhotsk planktonic foraminiferal study is Lipps and Warme (1966). They utilized the top three inches of eleven gravity cores, and data collected by Soviet scientists, finding Bradshaw's subArctic assemblage plus a few specimens of Globorotalia scitula. Lipps and Warme (1966) also cite discovery of specimens of Globigerinoides ruber and G. conglobatus (Shchedrina, 1958 in Lipps \& Warme, 1966) in areas influenced by the Sôya current, near the southern tip of Sakhalin. Greatest foraminiferal abundance and population diversity was found in waters influenced by Pacific inflow (Figure 5). Coastal regions were barren, and north of $54^{\circ} \mathrm{N}$, the only species found were N. pachyderma and G. bulloides. Nearly all the $N$. pachyderma specimens found were left-coiling. Another Sea of Okhotsk foraminiferal study finds $N$. pachyderma left-to-right coiling ratios upwards of $90 \%$ in sediments north of Hokkaido (Kitazato, 1978), in waters known to reach up to $20^{\circ} \mathrm{C}$ in summer (Takizawa, 1982). 
Constituent analysis of flux from the Sea of Okhotsk sediment trap used for this foraminiferal study (Honjo et al., 1995, in press) shows biogenic $\mathrm{CaCO}_{3}$, biogenic $\mathrm{SiO}_{2}$ (opal), and organic carbon ( $\mathrm{C}_{\text {org }}$ ) fluxes of $10.5,24.8$, and $1.7 \mathrm{~g} / \mathrm{m}^{2} / \mathrm{yr}$, respectively. Total flux for this sediment trap was $47.0 \mathrm{~g} / \mathrm{m}^{2} / \mathrm{yr}$, one of the highest seen in a sediment trap, third only to a trap in the Bering Sea (total flux $52.4 \mathrm{~g} / \mathrm{m}^{2} / \mathrm{yr}$ ) and one of the Station Papa deployments (Papa $82 / 83$, total flux $55.9 \mathrm{~g} / \mathrm{m}^{2} / \mathrm{yr}$ ) (Honjo et al., 1995, in press). Flux is concentrated in two blooms: an early summer bloom (yeardays 120-200) with maximum flux of $510.0 \mathrm{mg} / \mathrm{m}^{2} /$ day, and a fall bloom (yeardays 240-340) with maximum flux of $153.2 \mathrm{mg} / \mathrm{m}^{2} /$ day. The beginning of the early summer bloom coincides with the melt of seasonal sea ice coverage at the trap site. The fall bloom began with cooling from the summer SST maximum. Flux composition of the two blooms differs radically, with $80 \%$ of the total spring bloom flux consisting of $\mathrm{SiO}_{2}$, and $80 \%$ of the total fall bloom flux consisting of $\mathrm{CaCO}_{3}$ (Honjo et al., 1995, in press). Organic carbon fluxes also exhibit maxima during the two blooms: (23.2 (spring bloom) and 15.4 (fall bloom) $\mathrm{mg} \mathrm{C}_{\text {org }} / \mathrm{m}^{2} /$ day. Figure 6 shows $\mathrm{CaCO}_{3}, \mathrm{SiO}_{2}$, and $\mathrm{C}_{\text {org }}$ fluxes. Flux during the winter (yeardays 1-94) was too low to allow constituent analysis (Honjo et al., 1995, in press).

\section{$\underline{\text { Methods }}$}

Samples for this study come from the same MARK 7G-21 time-series (Honjo \& Doherty, 1988) sediment trap (aperture area $0.5 \mathrm{~m}^{2}$ ), deployed in the Sea of Okhotsk at the "Shoyu" Station: $53^{\circ} 19^{\prime} \mathrm{N} 149^{\circ} 50^{\prime} \mathrm{E}$ (Table 1). The trap deployment was part of Woods Hole Oceanographic Institution research in the Sea of Okhotsk with the collaboration of the Hydrographic Office, Maritime Safety Agency of Japan (Honjo et al., 1995, in press). The 
deployment period lasted from August 12, 1990 to August 12, 1991. Water depth at the trap site was 1166 meters. The trap was tethered to a bottom mooring, with trap deployment depth at 258 meters water depth. Twenty-one samples were collected during the deployment period, with a sample collection periods of 17.4 days. Samples will be referred to by the yearday (i.e. Jan 1 = yearday 1 , Dec 31 = yearday 365 ) of the midpoint of the sample collection period (Table 2). Aliquots of each collection cup sample (1/40th split of $<1 \mathrm{~mm}$ fraction) were used for this planktonic foraminiferal study. Other aliquots were used for constituent analysis and other studies. Details of trap deployment/recovery and initial sample preparation (up to and including sample splitting) can be found in Honjo et al. (in press).

Table 1 Trap deployment logistics.

\begin{tabular}{|l|l|}
\hline Trap location & $53^{\circ} 19^{\prime} \mathrm{N} 149^{\circ} 50^{\prime} \mathrm{E}$ \\
\hline Deployment data & August 12,1990 \\
\hline Recovery data & August 12, 1991 \\
\hline Water depth & 1166 meters \\
\hline Trap deployment depth & 258 meters \\
\hline Number of samples & 21 \\
\hline Collection period, one sample & 17.4 days \\
\hline
\end{tabular}

The aliquots used in this study were first disaggregated and cleaned of organic carbon using a 3\% calgon-peroxide solution (sodium hexametaphosphate $\left(\left(\mathrm{NaPO}_{3}\right)_{6}\right), 30 \%$ hydrogen peroxide, buffered to a $\mathrm{pH}$ of 7). This solution was added to the sample vial, and the contents were "swirled" on a regular basis (approximately every twenty minutes) to aid in disaggregation of fecal pellets. Each sample was then washed through a series of sieves $(500,250,150,125,63 \mu \mathrm{m})$ using deionized water. The supernatant containing the $<63 \mu \mathrm{m}$ fraction was preserved in a beaker. The sievedelimited fractions were washed from the sieves into beakers using deionized water. Contents of the beakers were concentrated onto Millipore $0.45 \mu \mathrm{m}$ 
gridded filters (white for $<63 \mu \mathrm{m}$ fraction, black for all others), using a Millipore Milliflex vacuum pump. To prevent cross-sample contamination, sieves were examined under a microscope and cleaned of any remaining foraminifera (typically 1-2 per sieve) before use with the next sediment trap sample.

Table 2 Sediment trap sample collection cup number and associated yearday

\begin{tabular}{|c|c|}
\hline $\begin{array}{c}\text { Collection } \\
\text { Period Number }\end{array}$ & $\begin{array}{c}\text { Mid-yearday of } \\
\text { collection period }\end{array}$ \\
\hline \hline 1 & 233 \\
\hline 2 & 250 \\
\hline 3 & 267 \\
\hline 4 & 285 \\
\hline 5 & 302 \\
\hline 6 & 320 \\
\hline 7 & 337 \\
\hline 8 & 354 \\
\hline 9 & 7 \\
\hline 10 & 24 \\
\hline 11 & 41 \\
\hline 12 & 59 \\
\hline 13 & 76 \\
\hline 14 & 94 \\
\hline 15 & 111 \\
\hline 16 & 128 \\
\hline 17 & 146 \\
\hline 18 & 163 \\
\hline 19 & 180 \\
\hline 20 & 198 \\
\hline 21 & 215 \\
\hline
\end{tabular}

All foraminifera were wet picked off the filters for the size fractions $>125 \mu \mathrm{m}$. The picked filters have been archived. Planktonic foraminifera were identified to the species level for the $150-250 \mu \mathrm{m}, 250-500 \mu \mathrm{m}$, and $500 \mu \mathrm{m}$ $1 \mathrm{~mm}$ size fractions. 
Foraminifera used for stable isotopic analyses come from the 150$250 \mu \mathrm{m}$ size fraction. These foraminifera were wet picked into pre-weighed aluminum boats; each boat contained exactly the number of foraminiferal tests desired for one isotopic analysis. The foraminiferal samples were allowed to dry, and then weighed using a Mettler MT5 microbalance (balance precision $1.0 \mu \mathrm{g})$. The samples were then emptied into the reaction vessels used for stable isotopic analyses. These reaction vessels were examined under a microscope to determine if any foraminifera had been lost during the transferal. If any shells had been lost, the remaining shells were transferred back to the weigh boat. Replacement shells were added, the sample was allowed to dry, and the boat was reweighed. Average sample weight for Neogloboquadrina pachyderma (left-coiling) was $29.1 \mu \mathrm{g}$ (6 shells/sample,

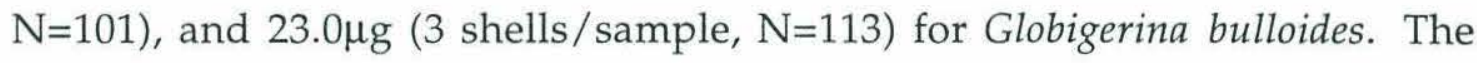
number of shells per analysis was chosen to capture as much of full population isotopic variability as possible (using small numbers of shells per sample) without degrading measurement precision. Six and three shells were used for analyses of N. pachyderma (1) and G. bulloides, respectively, with the following exceptions: G. bulloides samples at yeardays 54 (5 shells/sample) and 94 (6 shells/sample), and $10 \mathrm{~N}$. pachyderma (l) samples at yearday 302 (10 shells/sample). These twelve samples are indicated in Appendix B (marked with a * in the species column).

Stable isotopic analyses were performed using on a Finnigan MAT 252 mass spectrometer, with attached Kiel Carbonate Device. Samples were reacted with $\mathrm{H}_{3} \mathrm{PO}_{4}$ for 10 minutes at $70^{\circ} \mathrm{C}$. Analytical precision $(1 \sigma)$ for samples in the size range of this study's samples is: $\delta^{18} \mathrm{O}=0.10 \%$, and $\delta^{13} \mathrm{C}=$ $0.04 \%$ o ( $N=472$, NBS-19 standard, sample mass $25-50 \mu \mathrm{g}$ ). The isotopic data presented in this study incorporates A-line/B-line corrections (an instrument specific correction) and voltage corrections. (The voltage correction corrects 
for the deviation of small samples that are isotopically very different from the reference gas.) These corrections affect the isotopic composition in the first decimal place and second decimal place, respectively.

Size and morphometric analyses were performed on individual shells of N. pachyderma (l) and G. bulloides from the yearday 302 collection cup. Foraminiferal tests were glued to a slide, aperture side up, and digitized. Major axis length was determined using digital image analysis software (Bioscan Optimas 4.0). Repeat analysis of N. pachyderma (1) and G. bulloides specimens (100 digitizations of the same individual) give standard deviations $(1 \sigma)$ of $<1 \mu \mathrm{m}(1 \sigma)$ for major axis length. Individuals were sorted by size, using major axis length, and grouped into samples for isotopic analysis. As for the other stable isotopic analyses, six shells were used for each N. pachyderma (l) sample and three were used for G. bulloides. The first sample was assembled from the six (three) largest individuals, and each subsequent sample assembled from the next six (three) largest individuals. Weighing and isotopic analysis was done using the procedures described above. No individuals were lost during the weighing process; each sample contained the shells most closely grouped by major axis length.

Synoptic sea surface temperatures for this study come from the Advanced Very High Resolution Radiometer (AVHRR) Multichannel Sea Surface Temperature (MCSST) satellite data set. This satellite uses passively measured visible, near infra-red and infra-red spectral radiation bands to calculate SST (Smith, 1992). Raw data was processed by the University of Miami - Rosenstiel School of Marine and Atmospheric Science, and is available from the NASA Ocean Data System at the Jet Propulsion Laboratory (JPL). This data set gives weekly averages of SST, with a pixel dimension of $18 \mathrm{~km}$ by $18 \mathrm{~km}$. Where satellite observations are not available due to cloud cover, SST values are interpolated using available data. Accompanying each 
data set is a 'flag' file, indicating the number of measurements contributing to each pixel (Smith, 1992). Synoptic sea surface temperature for the trap location $\left(53^{\circ} 19^{\prime} \mathrm{N} 149^{\circ} 50^{\prime} \mathrm{E}\right)$ was taken as the average SST within a box $\left(52^{\circ} 18^{\prime}\right.$ - $54^{\circ} 18^{\prime} \mathrm{N}, 147^{\circ} 48^{\prime}-151^{\circ} 48^{\prime} \mathrm{E}$ ) around the trap deployment site (Figure 1).

This region was chosen to be representative of the central Sea of Okhotsk; it is 220 by $263 \mathrm{~km}$ (north-south by east-west) and contains 253 pixels. Utilizing this larger region increases the number of non-interpolated pixels; Figure 7 indicates the number of observations used to calculate each week's SST value. A long-term average SST was calculated using non-interpolated pixels for the trap deployment region (as defined above), using AVHRR MCSST data from 1982-1992. Comparison of synoptic sea surface temperatures with this longterm average indicates that sea surface temperatures during the trap deployment (Aug. '90 - Aug. '91) were within one standard deviation of the ten year average SST for the majority of the deployment period (Figure 8). This correspondence indicates that sea surface temperatures for deployment period were typical of the region.

Equilibrium calcite $\delta^{18} \mathrm{O}$ values for the water column were calculated using a calculated synoptic temperature profile (AVHRR MCSST at surface, linearly interpolated to $0.3^{\circ} \mathrm{C}$ at 50 meters; Figure 9), an average salinity profile for the region $50-55^{\circ} \mathrm{N}, 145-155^{\circ} \mathrm{E}$ (NODC data; Figure 10), the paleotemperature equation (O'Neil et al., 1969, as in Shackleton, 1973),

$$
\mathrm{T}=16.9-4.38\left(\delta^{18} \mathrm{O}_{\text {calcite }}-\delta^{18} \mathrm{O}_{\text {water }}\right)+0.10\left(\delta^{18} \mathrm{O}_{\text {calcite }}-\delta^{18} \mathrm{O}_{\text {water }}\right)^{2}
$$

and a Sea of Okhotsk-specific salinity - $\delta^{18} \mathrm{O}$ relationship for the upper 50 meters of the water column (C.S. Wong, IOS, Sidney, BC, Canada, pers. commun., 1995):

$$
\delta^{18} \mathrm{O}_{\text {water }}=0.42 \mathrm{~S}-14.9(\text { in SMOW })
$$


where $\mathrm{S}$ is salinity (\%o). $\delta^{18} \mathrm{O}_{\text {water }}$ was converted to the PDB scale using the conversion of Hut (1987):

$$
\mathrm{PDB}=\mathrm{SMOW}-0.27 \%
$$

Standard deviations for the average salinity profile (salinity binned and averaged every ten meters) used for the equilibrium calcite calculation were $0.2 \%$ or less within the upper 50 meters of the water column. A salinity variation of this magnitude changes calculated equilibrium calcite $\delta^{18} \mathrm{O}$ by $0.1 \%$. Note that sea surface $\delta^{18} \mathrm{O}_{\text {eq. calcite }}$ is calculated directly from AHVRR MCSST and involves no temperature interpolation.

The seasonal change in equilibrium calcite $\delta^{13} \mathrm{C}$ values was calculated using the equation of Grossman (1982) as in Thunell and Sautter (1992):

$$
\delta^{13} \mathrm{C}=\left(\delta^{13} \mathrm{C} \text { of } \Sigma \mathrm{CO}_{2}\right)+\left(10.51-\left(2980 /\left(\mathrm{T}_{\mathrm{w}}+273\right)\right)\right)
$$

where $T_{\mathrm{W}}$ is the temperature of ambient water $\left({ }^{\circ} \mathrm{C}\right)$. A Sea of Okhotsk relationship between $\delta^{13} C_{\Sigma \mathrm{CO} 2}$ values and phosphate measurements was developed for this study. This relationship uses a slope from the expected Redfield ratio relationship between $\delta^{13} \mathrm{C}$ and phosphate $(-0.93 \% / \mu \mathrm{m} / \mathrm{kg}$; Broecker \& Peng, 1982). The zero-phosphate intercept for this regression was calculated using phosphate and $\delta^{13} \mathrm{C}$ measurements from 50 meters water depth in the Sea of Okhotsk (phosphate $=1.53 \mu \mathrm{M} / \mathrm{l}$, C.S. Wong, IOS, Sidney, BC, Canada, pers. commun., $1995 ; \delta^{13} \mathrm{C}=0.94 \%$, L.D. Keigwin, pers. commun. 1995):

$$
\delta^{13} \mathrm{C}_{\Sigma \mathrm{CO} 2}=-0.93 \text { Phosphate }+2.36
$$


The phosphate and the temperature data used for the $\delta^{13} \mathrm{C}_{\text {eq. calcite calculation }}$ come from a subset of the NODC data set (L.D. Talley, pers. commun. 1995); water temperatures used were associated with the phosphate measurement, rather than synoptic (i.e. calculated from AVHRR data) temperatures. Due to the scarcity of phosphate measurements, any phosphate measurement from within the Sea of Okhotsk was used. An average phosphate profile was calculated for each month; these average phosphate profiles were then used

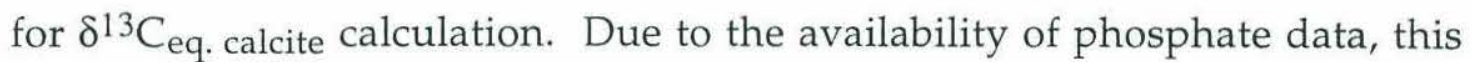
$\delta^{13} C_{\text {eq. calcite }}$ calculation was only possible during summer months.

\section{Study Results and Discussion}

Planktonic foraminiferal flux and assemblages were determined for the yearlong sediment trap deployment for the $>150 \mu \mathrm{m}$ size fractions. Stable isotopic measurements were made on the yearlong time series for two species: Neogloboquadrina pachyderma (1), and Globigerina bulloides. Sizemorphometric and isotopic analyses were performed on N. pachyderma (1) and G. bulloides specimens from the yearday 302 sample collection cup for analysis of the variability inherent within a population. Assemblage, yearlong isotopic time series, and population variability results are presented in separate subsections below.

In brief, the results of this study show that planktonic foraminiferal assemblages and stable isotopes underestimate both the average SST and the seasonal maximum SST for the region. Average SST is underestimated by $\sim 5^{\circ} \mathrm{C}$, seasonal maximum SST is also underestimated by $\sim 5^{\circ} \mathrm{C}$. These biases are a result of the calcification depth of the foraminifera: ambient water temperatures at calcification depths (calculated from $\delta^{18} \mathrm{O}_{\text {eq. calcite) }}$ are approximately $5^{\circ} \mathrm{C}$ colder than sea surface temperatures. This interpretation 
was made by a direct comparison of these planktonic foraminiferal paleoceanographic proxies and synoptic sea surface temperature measurements.

\section{Faunal Counts}

\section{$\underline{\text { Results - Faunal Counts }}$}

Faunal counts show two blooms of planktonic foraminifera in the $>150 \mu \mathrm{m}$ size fractions, corresponding to the two blooms seen in constituent analysis of this trap (Honjo et al., 1995, in press) (Figure 11). Maximum planktonic foraminiferal flux for the early summer $\mathrm{SiO}_{2}$-rich bloom was 5940 indiv $/ \mathrm{m}^{2} /$ day. Peak foraminiferal flux rates for the deployment occurred during the $\mathrm{CaCO}_{3}$-rich fall bloom: 12,046 indiv $/ \mathrm{m}^{2} /$ day. Approximately $74 \%$ of the yearly foraminiferal flux $(>150 \mu \mathrm{m})$ was during the fall bloom.

Only two species exceed $10 \%$ of the total foraminiferal population: Neogloboquadrina pachyderma (left-coiling) and Globigerina bulloides. G. quinqueloba, N. dutertrei, and N. pachyderma (right) were seen in lower abundances (Figure 12). Small numbers of G. uvula, G. glutinata and Globorotalia scitula were also observed. Table 3 presents the cumulative species abundances. Population makeup of the two foraminiferal blooms differed significantly. N. pachyderma (1) were abundant during both blooms, whereas G. bulloides and G. quinqueloba showed large peaks during the fall bloom, but only minor peaks during the early summer bloom. Figure 13 shows $G$. bulloides flux broken down by size fractions; large size fraction $(>250 \mu \mathrm{m})$ G. bulloides dominated during the fall bloom. Appendix A gives raw counts for each sediment trap collection cup, broken down by species and size fraction. 
The $N$. pachyderma left-to-right coiling ratio (calculated as \#left/\#(left+right)) was $>98 \%$ left-coiling in all trap samples, regardless of season and sea surface temperature (Figure 14).

Table 3 Planktonic foraminiferal species abundance as a percentage of total yearly foraminiferal flux $(>150 \mu \mathrm{m})$.

\begin{tabular}{||l|c||}
\hline \multicolumn{1}{|c|}{ Species } & $\begin{array}{c}\text { Percentage of } \\
\text { Total Yearly Flux }\end{array}$ \\
\hline N. pachyderma (1) & $57 \%$ \\
\hline G. bulloides & $31 \%$ \\
\hline G. quinqueloba & $8 \%$ \\
\hline N. dutertrei & $3 \%$ \\
\hline N. pachyderma ${ }^{\wedge}(\mathrm{r})$ & $1 \%$ \\
\hline G. uvula & $<1 \%$ \\
\hline G. glutinata & $<1 \%$ \\
\hline G. scitula $^{\prime}$ & $<1 \%$ \\
\hline other & $<1 \%$ \\
\hline
\end{tabular}

\section{Discussion - Faunal Counts}

The magnitude of the Okhotsk Sea foraminiferal blooms is consistent with the high productivity seen at this location, and is comparable to that found at Station Papa, another high productivity North Pacific site (Honjo et al., 1995, in press). The population composition, however, differs significantly between these two locations. Maximum foraminiferal fluxes $\left(>125 \mu \mathrm{m}\right.$ size fraction) seen at Station Papa $\left(50^{\circ} \mathrm{N}, 145^{\circ} \mathrm{W}\right)$ range from 6673 indiv/ $\mathrm{m}^{2} /$ day (Papa 82/83) to 22,678 indiv/ $\mathrm{m}^{2} /$ day (Papa 84/85) (Sautter \& Thunell, 1989). There are two blooms at Station Papa, as in the Sea of Okhotsk: a spring bloom from April to June/July (yeardays 90 to 150/180) and a fall bloom occurring during October or November (yeardays $270-300$ or 300330). These blooms are both $\mathrm{SiO}_{2}$-dominated events. During 1983, a year 
influenced by El Niño, the fall bloom was larger than the spring bloom, but in 1985, a "normal" year, the converse was true. Comparison of typical bloom "dominance" with the Sea of Okhotsk is not possible, due to incomplete flux records at Papa for other years. Foraminiferal flux for the four-year Papa time series (average SST range $5.5^{\circ}$ to $12.7^{\circ} \mathrm{C}$ ) was dominated by warmer water species: G. quinqueloba, N. pachyderma (1), N. pachyderma (r) with smaller percentages of G. glutinata, G. bulloides and O. universa. The relative proportion of left- and right-coiling $N$. pachyderma varied throughout the Papa deployment period. At no time during the Papa deployments was the abundance of $G$. bulloides greater than $\sim 5 \%$.

High latitude North Atlantic sediment trap studies find both lower flux and different foraminiferal assemblages than the Sea of Okhotsk. Maximum flux ( $>150 \mu \mathrm{m}$ size fraction) at the Marine Research Institute trap (MRI, $63^{\circ} \mathrm{N}$, $22^{\circ} \mathrm{W}$ ) was $127 \mathrm{indiv} / \mathrm{m}^{2} /$ day and $2388 \mathrm{indiv} / \mathrm{m}^{2} /$ day at the Iceland Plateau site (IP, $\left.68^{\circ} \mathrm{N}, 13^{\circ} \mathrm{W}\right)$ (Wolfteich, 1994). The planktonic foraminiferal population at these traps was dominated by G. quinqueloba, G. bulloides and N. pachyderma (r) at MRI (SST range $\sim 11.5^{\circ}$ to $6^{\circ} \mathrm{C}$ ) and N. pachyderma (l) and G. quinqueloba at IP (SST range $-2^{\circ}$ to $8^{\circ} \mathrm{C}$ ).

Although the overall planktonic foraminiferal population makeup from this Okhotsk sediment trap experiment is different from that seen in other high latitude sediment traps, it is very similar to that seen in Sea of Okhotsk sediments by Lipps and Warme (1966) and in North Pacific plankton tows in sub-Arctic waters by Bradshaw (1959). A population dominated by $N$. pachyderma (1) and G. bulloides appears to be characteristic of the Sea of Okhotsk, as this is seen in sediments (Lipps \& Warme, 1966) as well as in this sediment trap. The association of the cold-water species $N$. pachyderma (1) and warmer water species such as G. bulloides and G. quinqueloba may be related to the large seasonal sea surface temperature variability caused by the 
highly stratified upper water column. Recent work in the California Current by Ortiz et al. (1995) finds high abundances of N. pachyderma (r), G. bulloides, and G. quinqueloba in regions of high productivity. Although the $N$. pachyderma they find are right-coiling, it is not unreasonable to assume similar behavior for the left-coiling morphotype of the species. The high abundances of these three species in the highly productive Sea of Okhotsk suggests that the results of Ortiz et al. (1995) linking these species to productivity may be applicable on a more global scale.

Similar assemblages rich in N. pachyderma (1) and G. bulloides are seen during Stage 3 in downcore results from the North Atlantic (Oppo \& Lehman, 1995). Oppo and Lehman (1995) link decreased North Atlantic Deep Water (NADW) formation with sea surface temperature cooling from Dansgaard-Oeschger events. During late Stage 3 (25-50 kyr before present) they identify nine events with decreases in benthic foraminiferal $\delta^{13} \mathrm{C}$ associated with increases in N. pachyderma (l) percentages. Prior to each of these events, their record shows planktonic foraminiferal assemblages with high percentages of $N$. pachyderma (1) ( 50-60\% total plank. foram.) and $G$. bulloides ( 20-25\% total plank. foram.). The similarity of these assemblages to this study's Sea of Okhotsk assemblage suggests the possibility of strong seasonality. As in the Sea of Okhotsk, the abundance of both the cold-water N. pachyderma (l) and the warmer-water G. bulloides may be linked to large seasonal SST changes. Benthic $\delta^{13} \mathrm{C}$ values are high (characteristic of strong NADW formation), indicating that winter temperatures are low enough to allow deep convection. From the work of Ortiz et al. (1995), the Stage 3 assemblages may also represent times of high productivity.

The standard reconstruction of SST using foraminiferal assemblages (e.g. CLIMAP, 1976; Kellogg, 1973) would run into difficulties in the Sea of Okhotsk due to the dominance of $N$. pachyderma(l). Other than the 
abundance of $N$. pachyderma(1), the overall Sea of Okhotsk assemblage is similar to the globally defined subpolar assemblage of Bé and Tolderlund (1971). They place N. pachyderma (right-coiling) in their subpolar group, and define a polar assemblage consisting solely of $N$. pachyderma(left-coiling). The changeover point between left- and right-coiling $N$. pachyderma in the North Atlantic approximates the $7.2^{\circ} \mathrm{C}$ isotherm from April (Ericson, 1959). Recent sediment trap work of Wolfteich (1994) found the left/right changeover point at SST's of $7.4^{\circ} \mathrm{C}$. SST for the N. pachyderma (l) dominated spring bloom ranged between $0^{\circ}$ and $6.8^{\circ} \mathrm{C}$. A large portion of the total $N$. pachyderma (l) flux, however, occurred during the fall bloom when SST ranged between $14.8^{\circ}$ and $3.4^{\circ} \mathrm{C}$ (Figure 15). The first third of this fall bloom had sea surface temperatures warmer than $10^{\circ} \mathrm{C}$. This would appear to be contrary to the frequently cited results of Bé and Tolderlund (1971) who state that $N$. pachyderma (l) is not found in waters warmer than $10^{\circ} \mathrm{C}$. The isotopic evidence presented below, however, suggests $N$. pachyderma (1) calcifies between 30 and 40 meters water depth, where temperature is no greater than $7^{\circ} \mathrm{C}$ (consistent with Bé and Tolderlund, 1971). Using the preponderance of left-coiling $N$. pachyderma and the $10^{\circ} \mathrm{C}$ limit would underestimate maximum seasonal sea surface temperature by almost $5^{\circ} \mathrm{C}$. The results of this study show that in highly stratified waters $N$. pachyderma(l) can live at depth, in waters colder than $10^{\circ} \mathrm{C}$, yet SST's can be considerably warmer than $10^{\circ} \mathrm{C}$. In this way, the apparent $10^{\circ} \mathrm{C} \mathrm{SST} \mathrm{"limit"}$ for $N$. pachyderma(l) is violated, and reconstructions may seriously underestimate the seasonal maximum sea surface temperatures.

This underestimation of maximum summer sea surface temperature from $N$. pachyderma(l) abundance has repercussions for paleoceanographic SST reconstructions, especially for rapid events such as Heinrich events (e.g. Lehman \& Keigwin, 1992) and Dansgaard-Oeschger (D-O) events (e.g. Bond et al., 1993) which have often been delineated using $N$. pachyderma $(1)$ 
percentages. If the temperature tolerance of $N$. pachyderma $(\mathrm{l})$ is higher than the $10^{\circ} \mathrm{C}$ reported by Bé and Tolderlund (1971), the magnitude of the SST decreases associated with Heinrich and D-O events may not be as large as had been previously believed (on the order of $5^{\circ} \mathrm{C}$; Bond et al., 1993). These events can be accommodated simply by a deepening (and thus cooling) of foraminiferal calcification depths. This change in foraminiferal habitat might be due to freshening of the sea surface, in the case of Heinrich events, or the crossing of some other ecological threshold.

There are several potential explanations for the differing responses of N. pachyderma(l) and G. bulloides during the two blooms: food preference, salinity tolerance and temperature tolerance. First, the negative correlation of silica flux and G. bulloides may be a manifestation of food preference in G. bulloides. Volkov and Chuchukalo (1985) state that Coscinodiscus species dominate the phytoplankton of the southern part of the Sea of Okhotsk in April; examination of the filters from which the foraminifera were picked showed abundant centric diatoms during the spring bloom. Gowing (1989) found diatom frustules, diatoms with cytoplasm, and fragments of silica within food vacuoles of planktonic foraminifera collected from the water column in the Weddell Sea. Gowing does not identify foraminiferal species, but from provenance, these specimens are almost certainly N. pachyderma (l). Laboratory experiments have shown that G. bulloides will consume diatoms (Lee, et al., 1966), but further laboratory work of Anderson et al. (1979) has found that foraminiferal species which consume diatoms in the laboratory do not ingest them in the field, suggesting significantly different trophic strategies in the two environments. The study of Anderson et al. did not include G. bulloides (or N. pachyderma) individuals; the trophic strategy of G. bulloides in oceanic environments is unclear as of yet. Comparison of $G$. bulloides and silica flux from other sediment trap locations, however, shows either positive or no correlation between the two fluxes at Station Papa 
(Honjo, 1984; Honjo \& Manganini, unpublished; Sautter \& Thunell, 1989), the North Atlantic Bloom Experiment (Honjo \& Manganini, 1993; Wolfteich, 1994), the Arabian Sea (Curry, et al., 1992; Honjo, 1996 pers. commun.), and the San Pedro Basin (Thunell \& Sautter, 1992; Thunell, et al., 1994). This lack of correlation suggests that the trophic strategy of G. bulloides does not exclude diatoms. Conclusive proof or disproof of this food preference hypothesis is not possible without increased understanding of the trophic strategies of G. bulloides in oceanic settings. This might be accomplished (as in Gowing, 1989) by microscopic examination of food vacuoles of G. bulloides specimens collected from the wild.

Differing salinity tolerance between N. pachyderma (l) and G. bulloides might also account for the differing bloom responses. The early summer bloom began when seasonal sea ice melt commenced at the trap location (Honjo et al., 1995, in press); the accompanying lower salinity water may pass an ecological threshold for G. bulloides but not for N. pachyderma (1). Kitani (1973) finds Sea of Okhotsk summer surface salinities $<32.8 \%$. Through the summer season, surface salinities increase due to evaporation $(\Delta S \approx 1 \%$; Kitani, 1973), perhaps recrossing the foraminiferal tolerance boundary by the time of fall bloom. The foraminiferal ecology work of Bé (1977) gives maximum species abundances at average salinities $( \pm 1 \sigma)$ of $34.8 \pm 5.1 \%$ for $G$. bulloides and $34.1 \pm 2.9 \%$ for N. pachyderma. Neither of these abundance ranges would indicate salinity as a limiting factor for these species in the Sea of Okhotsk. An increased knowledge of both the full seasonal salinity range in the trap location and the ecological tolerances of G. bulloides and N. pachyderma will help clarify this salinity tolerance hypothesis.

Finally, and perhaps most convincingly, temperature tolerance may be the cause of the different assemblages within the two blooms. G. bulloides is a warmer water species than N. pachyderma (1). Characteristic temperature 
ranges where G. bulloides are found are $16.5 \pm 7.0^{\circ} \mathrm{C}$ (Pacific Ocean, Berger, 1969) and $13.4 \pm 7.1^{\circ} \mathrm{C}$ (Indian Ocean, Bé, 1977), as opposed to $13.1 \pm 3.0$ (a high estimate from Berger, 1969) and $4.8 \pm 5.5^{\circ} \mathrm{C}$ (Bé, 1977) for $N$. pachyderma. Winter sea surface temperatures for the trap deployment went as low as $-1.2^{\circ} \mathrm{C}$, far below any temperature range suggested for $G$. bulloides, but still within the $N$. pachyderma temperature range. These low wintertime temperatures might result in a winter kill of the G. bulloides population. What specimens were found in the winter sample collection cups were small and poorly calcified. The early summer bloom, where G. bulloides makes up only a minor peak, also has small G. bulloides individuals. Laboratory experiments on G. sacculifer have found that ecological stress decreases final shell size (Bé, et al., 1981). By analogy, this would suggest that the winter and early summer bloom G. bulloides populations may be under some form of ecological stress.

There are several potential sources for the G. bulloides population of the fall bloom: an extant "seed" population, or repopulation of the area. Although the summertime G. bulloides flux or population is small, it may be sufficient to seed the fall bloom. Alternatively, the trap deployment region may be repopulated by means of the North Pacific inflow. Zenkevitch (1963) traces the warm currents influenced by Pacific waters can be traced by the presence of the copepod Calanus tonsus, and Lipps and Warme (1966) find richer planktonic foraminiferal assemblages in areas influenced by this inflow. They identify the species N. dutertrei, G. quinqueloba, G. glutinata, G. uvula, and T. scitula as characteristic of the North Pacific inflow; these species are present in plankton tows in the North Pacific along the Kuril Island chain (Bradshaw, 1959) indicating the viability of this region as a source. These marker species were found in highest abundances in the sediment trap during the fall bloom. Although we cannot currently distinguish between these two possible sources for the fall bloom population, the abundance of 
North Pacific species during the fall bloom suggests that some repopulation may occurring.

Unfortunately, the seasonality of planktonic foraminiferal flux is not preserved in sediments, and we must rely on the total population assemblage for reconstruction of past conditions in the overlying water column. When collapsed into total assemblage, the only clue of differing foraminiferal response within these two blooms is the odd association of N. pachyderma (1) and G. bulloides. Although we cannot currently distinguish between the three hypotheses listed above, evidence is strongest for the temperaturetolerance hypothesis. If this hypothesis is correct, the planktonic foraminiferal assemblage seen in the Sea of Okhotsk can be considered indicative of a region with large seasonal swings in sea surface temperature.

\section{Stable Isotopes - Yearlong Time Series}

\section{Results - Stable Isotopes}

Stable isotopic analyses were performed on G. bulloides and N. pachyderma (1) samples from the $125-250 \mu \mathrm{m}$ size fraction. Replicate analyses were performed when there was sufficient material within a sample collection cup. Isotopic data is found in Appendix B. A large number of replicate measurements were made at yearday 302 , for the purposes of population variability analysis (discussed in this section) and size/mass stable isotope analysis (discussed below).

Strong seasonal signals were seen in the yearlong $\delta^{18} \mathrm{O}$ time series for both species. $\delta^{18} \mathrm{O}$ values reached a peak for $N$. pachyderma (1) $(\sim 2.9 \%)$ just before the early summer bloom, between yeardays 90 and 120 (Figure 16). Peak $\delta^{18} \mathrm{O}$ values for $G$. bulloides occurred around yearday 150, during the 
early summer bloom, with high values $\sim 2.8 \%$ (Figure 17). Lowest $\delta^{18} \mathrm{O}$ values for both species occurred during the fall bloom, around yearday 300 , with lows of $1.0 \%$ ( $N$. pachyderma (1)) and 1.5\% (G. bulloides). Maximum magnitude of the seasonal $\delta^{18} \mathrm{O}$ signal (maximum to minimum $\delta^{18} \mathrm{O}$ value) was approximately $\Delta \delta^{18} \mathrm{O}=2.0 \%$ for $N$. pachyderma (l) and $1.3 \%$ for $G$. bulloides. Using mean sample collection cup values yields a seasonal range of $\Delta \delta^{18} \mathrm{O}=1.2 \%$ for $N$. pachyderma (l) and $1.15 \%$ for G. bulloides. Student's test indicates no statistical difference ( $95 \%$ confidence interval) between the mean annual $\delta^{18} \mathrm{O}$ of the $N$. pachyderma (l) and G. bulloides records. Population variability was very high in both species: the range of $\delta^{18} \mathrm{O}$ values seen at yearday 302 was $1 \%$ for both N. pachyderma (l) and G. bulloides.

There is a strong seasonal signal in $\delta^{13} \mathrm{C}$ for $N$. pachyderma (1). Low values $(\sim 0.3 \%$ ) occurred at yearday 94 , with highest values (up to $1.2 \%$ ) at yearday 302 , for a $\Delta \delta^{13} \mathrm{C} \approx 1.0 \%$ (Figure 18). Means for each sample collection cup yield a seasonal $\Delta \delta^{13} \mathrm{C}$ of $0.5 \%$. A seasonal signal is not as clear in the $G$. bulloides time series (Figure 19). There is a general trend of low $\delta^{13} \mathrm{C}$ in winter and spring (yeardays 330 to 94 ), and higher $\delta^{13} \mathrm{C}$ in summer, with a yearly $\delta^{13} \mathrm{C}$ range (maximum to minimum measurement) around $1.3 \%$. The seasonal $\Delta \delta^{13} \mathrm{C}$ from collection cup means is $1.1 \%$. Mean annual G. bulloides $\delta^{13} \mathrm{C}$ values are significantly lower than $N$. pachyderma (l) values $(95 \%$ confidence interval). Population variability within a sample collection cup (yearday 302) is smaller for $\delta^{13} \mathrm{C}$ than for $\delta^{18} \mathrm{O}$, with a $\Delta \delta^{13} \mathrm{C}$ of $0.5 \%$ for $N$. pachyderma (l) and $0.6 \%$ for G. bulloides .

Plotting $\delta^{18} \mathrm{O}$ versus $\delta^{13} \mathrm{C}$ shows a clear linear trend in $N$. pachyderma (l) values $\left(\mathrm{r}^{2}=0.82\right)$, going from high $\delta^{18} \mathrm{O}$ - low $\delta^{13} \mathrm{C}$ (cold, nutrient rich) to low $\delta^{18} \mathrm{O}$ - high $\delta^{13} \mathrm{C}$ (warm, nutrient poor) values (Figure 20). This is the trend that would be expected given seasonal hydrographic variation and the typical vertical structure of $\delta^{18} \mathrm{O}$ and $\delta^{13} \mathrm{C}$ in 
the water column (as will be discussed below). G. bulloides values show no clear trend $\left(r^{2}=0.02\right)$ (Figure 21).

\section{Discussion - Stable Isotopes}

Foraminiferal $\delta^{18} \mathrm{O}$ values reach a yearly minimum, or temperature maximum, around yearday 302. Synoptic AVHRR MCSST data shows maximum SST at yearday 240, for an apparent foraminiferal offset (a delay in flux) of 60 days. An offset is also apparent in $\delta^{13} \mathrm{C}$ measurements: $N$. pachyderma (1) $\delta^{13} \mathrm{C}$ values are highest during the latter half of the fall bloom (yeardays 320+). Since organic matter is preferentially enriched in light carbon ( ${ }^{12} \mathrm{C}$ ) (Broecker \& Peng, 1982), highest $\delta^{13} C_{\text {foram }}$ should occur at about the time of highest productivity and greatest removal of carbon from the water column. When compared to organic carbon $\left(\mathrm{C}_{\text {org }}\right)$ flux, the $N$. pachyderma $\delta^{13} \mathrm{C}$ increase occurs at least two sample collection periods after the beginning of the bloom (Figure 22). The combination of these two offsets suggests that the majority of foraminiferal calcification occurred at least two collection periods (i.e. 35 days) before collection in the sediment trap. Part of this offset is due to the delay between foraminiferal demise and collection within the sediment trap at 258 meters. This settling time is unlikely to be greater than a few days; Sautter and Thunell (1991) used a one week delay for a trap deployed at 500 meters. The majority of the offset is most likely due to the lifespan of an individual foraminifera, as the magnitude of the offset is not dissimilar to the length of a planktonic foraminiferal lifespan: on the order of 25 to 50 days (Caron \& Swanberg, 1990). Thus, a 35 day offset (2 sample collection periods) has been applied to isotopic data for comparison with synoptic SST and equilibrium calcite $\delta^{18} \mathrm{O}$ and $\delta^{13} \mathrm{C}$ calculations.

Figures 23 and 24 show the comparison of the calculated seasonal variation of equilibrium calcite $\delta^{18} \mathrm{O}$ and foraminiferal $\delta^{18} \mathrm{O}$ values (35 day 
offset applied). For both N. pachyderma (1) and G. bulloides, the assumption that $\delta^{18} \mathrm{O}$ is at equilibrium yields calcification depths between 20 and 40 meters through summer and fall. This is consistent with what has been found in other studies: around 60 meters for N. pachyderma (r) and within the upper 90 meters for G. bulloides in the San Pedro Basin (Sautter \& Thunell, 1991), in the upper 50 meters for N. pachyderma (1) in the Arctic Ocean (Carstens \& Wefer, 1992), and in the upper 25 meters for the majority of G. bulloides in the Panama Basin (Fairbanks et al., 1982). In the winter and spring, however, measured $\delta^{18} \mathrm{O}_{\text {foram }}$ values are 0.4 to $0.8 \%$ lighter than those calculated for the water column.

There are two possible explanations for this phenomenon. Since wintertime $\delta^{18} \mathrm{O}_{\text {foram }}$ values are similar to those found during the fall bloom (Figures 16 and 17), it is possible that the winter population may represent a holdover from the fall bloom. Bé et al. (1981) have found increasing foraminiferal lifespans with decreasing frequency of feeding, although the lifespans they find (on the order of 50 days) are not long enough to span the winter. This food availability hypothesis is consistent with the low productivity indicated by the low total flux rates during this time. Alternatively, this wintertime population may have its source in the North Pacific inflow. Synoptic SST's for the North Pacific outside the Kuril Island chain are $\sim 2^{\circ} \mathrm{C}$ warmer than in the Sea of Okhotsk for this period of the trap deployment. This temperature gradient has the right sense for the observed $\delta^{18} \mathrm{O}_{\text {foram }}$ values; expected $\delta^{18} \mathrm{O}$ values would be on the order of $0.5 \%$ lower. It is not currently possible to distinguish between these two hypotheses for the low $\delta^{18} \mathrm{O}$ values during the winter.

Figure 25 shows the seasonal signal calculated for equilibrium calcite $\delta^{13} \mathrm{C}$. This calculation is limited seasonally by the availability of historical phosphate data. The patchiness of $\delta^{13} \mathrm{C}$ values below 100 meters is an artifact 
of data availability. Above 100 meters phosphate measurements were more abundant, and the range of $\delta^{13} \mathrm{C}$ values is more likely to reflect actual water column conditions. A comparison of foraminiferal $\delta^{13} \mathrm{C}$ (35 day offset

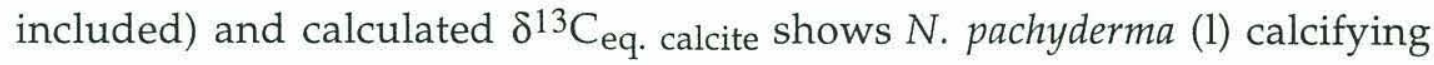
between 25 and 45 meters (Figure 26), a good agreement with the calcification

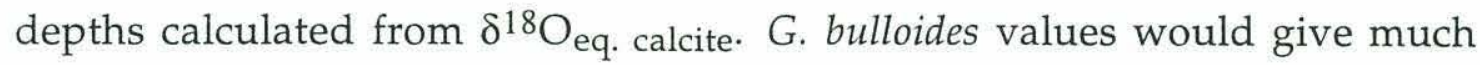
deeper calcification depths; the heaviest G. bulloides $\delta^{13} \mathrm{C}$ measurements $(\sim 0 \%)$ would indicate calcification no shallower than 100 meters. This would place the foraminifera within the biologically sparse dichothermal layer (Zenkevitch, 1963). The lightest $\delta^{13} \mathrm{C}$ values for G. bulloides ( $<-1.0 \%$ ) would have the foraminifera calcifying below the trap deployment depth.

One of the crucial questions for any paleoceanographic study utilizing planktonic foraminifera is whether a particular species of foraminifera calcifies in equilibrium with water column conditions, and thus whether it accurately reflects temperature $\left(\delta^{18} \mathrm{O}\right)$ and nutrient concentrations $\left(\delta^{13} \mathrm{C}\right)$. Previous coretop based work has suggested a slight $\delta^{18} \mathrm{O}$ vital effect for $N$. pachyderma, on the order of $-0.4 \%$, making $N$. pachyderma lighter than

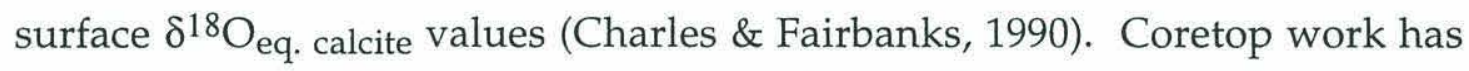
also shown $N$. pachyderma to be either light in $\delta^{13} \mathrm{C}$ (Charles \& Fairbanks, 1990; Labeyrie \& Duplessy, 1985) or completely out of equilibrium (Keigwin \& Boyle, 1989). Recent sediment trap work of Sautter and Thunell (1991) suggests that $N$. pachyderma does calcify in equilibrium for both isotopes. They show $N$. pachyderma calcifying around 60 meters water depth, not at the sea surface as many of these previous studies have assumed. This is consistent with previous work for where $\delta^{13} C_{\text {pachy }}$ appeared light, but runs counter to a negative $\delta^{18} \mathrm{O}$ vital effect, which would indicate warmer/shallower calcification than possible in surface waters. Based on the $\delta^{18} \mathrm{O}-\delta^{13} \mathrm{C}$ relationship and calcification depths, the current study suggests that $N$. pachyderma (l) calcifies in equilibrium with both $\delta^{18} \mathrm{O}$ and $\delta^{13} \mathrm{C}$. The 
strong $\delta^{18} \mathrm{O}-\delta^{13} \mathrm{C}$ trend corresponds with the trend expected from seasonal variations in hydrography, and calcification depths calculated from $\delta^{18} \mathrm{O}$ and $\delta^{13} \mathrm{C}$ agree to within 10 meters. A seasonally constant vital effect would not clearly affect the $\delta^{18} \mathrm{O}-\delta^{13} \mathrm{C}$ relationship, as it would not change the slope of the relationship, but would only change the zero intercept. Such an offset would be seen in calcification depths; within the confidence of the equilibrium calcite $\delta^{18} \mathrm{O}$ and $\delta^{13} \mathrm{C}$ calculations, this is not the case. Applying previously measured vital effects would move the $\delta^{18} \mathrm{O}$-calculated calcification depths $\sim 10$ meters deeper in the water column, while the $\delta^{13} \mathrm{C}$ offset would move N. pachyderma (1) shallower by $\sim 20$ meters. The correspondence in calcification depths without vital effect "correction" suggests that $N$. pachyderma (l) is nearly in equilibrium.

The similarity of the G. bulloides and N. pachyderma (1) $\delta^{18} \mathrm{O}$ time series (95\% confidence interval) argues against a vital effect for G. bulloides, unless $N$. pachyderma (l) is subject to a $\delta^{18} \mathrm{O}$ vital effect of the same magnitude. For G. bulloides, studies show deviation from oxygen isotopic equilibrium either minimal (Curry \& Matthews, 1981; Kroon \& Ganssen, 1989; Prell \& Curry, 1981) or 1.08\%o light (Kahn \& Williams, 1981). Results from the yearlong time series suggests no more than a minimal offset from equilibrium. The mean of the $\delta^{18} \mathrm{O}_{\text {bull }}$ measurements at yearday 302 are

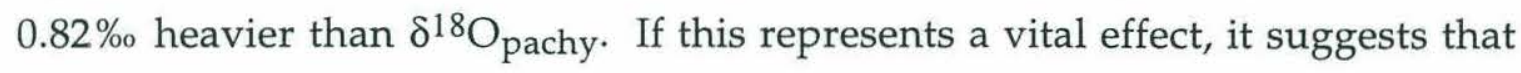
G. bulloides may be isotopically heavy. Alternatively, this difference can be accommodated within the water column with slightly different calcification depths; it is not necessary to call on isotopic disequilibrium to explain this difference between $\delta^{18} \mathrm{O}_{\text {bull }}$. and $\delta^{18} \mathrm{O}_{\text {pachy. Comparison of the G. bulloides }}$ and $N$. pachyderma (l) $\delta^{13} \mathrm{C}$ records, however, suggest that $G$. bulloides is $\sim 1 \%$ low in carbon isotopes. The direction of the offset agrees with previous work with $G$. bulloides, which has found $\delta^{13} \mathrm{C}$ deviations from equilibrium ranging between -3.0 and $-4.3 \%$ (Kahn \& Williams, 1981; Kroon \& Ganssen, 
1989; Prell \& Curry, 1981; Williams, et al., 1977). The lack of trend in $\delta^{18} \mathrm{O}-$ $\delta^{13} \mathrm{C}$ space (Figure 21) suggests that the $\delta^{13} \mathrm{C}$ vital effect is not a constant offset.

Figure 27 shows water temperatures calculated using foraminiferal $\delta^{18} \mathrm{O}$ values, the O'Neil paleotemperature equation (as in Shackleton, 1973) and an average salinity of $32.59 \%$. This salinity value is the average of the upper 50 meters of the salinity profile used to calculate equilibrium calcite, and corresponds to a $\delta^{18} \mathrm{O}_{\text {water }}$ of $-1.48 \%$ (PDB). These paleotemperature values assume that $N$. pachyderma (l) and G. bulloides were calcifying in $\delta^{18} \mathrm{O}$ equilibrium. The range of $\delta^{18} \mathrm{O}_{\text {foram }}$ calculated water temperatures is from $6.65^{\circ}$ to $-0.50^{\circ} \mathrm{C}$ for $N$. pachyderma (l) and from $4.83^{\circ}$ to $-1.52^{\circ} \mathrm{C}$ for $G$. bulloides, a much smaller range than the actual synoptic SST range of $14.8^{\circ}$ to $-1.2^{\circ} \mathrm{C}$. Note that the full seasonal range of sea surface temperatures is not seen at calcification depths, resulting in a damped signal. These isotopic results show $N$. pachyderma (l) calcifying well below the $10^{\circ} \mathrm{C}$ limit set by Bé and Tolderlund (1971), despite significantly warmer sea surface temperatures. A comparison of the seasonal temperature profile (from Figure 9) and the $\delta^{18} \mathrm{O}$-calculated calcification depths for $N$. pachyderma (l) and G. bulloides (from Figures 16 and 17) suggests that both species may be calcifying within preferred temperature ranges: $2^{\circ}$ to $7^{\circ} \mathrm{C}$ for $\mathrm{N}$. pachyderma (l) and $0.5^{\circ}$ to $5^{\circ} \mathrm{C}$ for G. bulloides. N. pachyderma (l) appears more closely tied to temperature, with most measurements falling around the $2^{\circ} \mathrm{C}$ isotherm. Sautter and Thunell (1991) see similar but much higher temperature ranges for these species in the San Pedro Basin: N. pachyderma (r) $11^{\circ}$ to $15^{\circ} \mathrm{C}$ (majority $\sim 12^{\circ} \mathrm{C}$ ), G. bulloides $10^{\circ}$ to $15^{\circ} \mathrm{C}$ (using $\delta^{18} \mathrm{O}, 10^{\circ}$ to $11^{\circ} \mathrm{C}$ if only $\delta^{13} \mathrm{C}$ used).

When the foraminiferal temperature measurements are weighted by flux (i.e. by proportion of total yearly flux that occurred during each particular collection period), as would be seen in the sediments, the resultant average temperatures are $2.37^{\circ} \mathrm{C}$ for $\mathrm{N}$. pachyderma (l) and $2.29^{\circ} \mathrm{C}$ for G. bulloides. 
Average AVHRR MCSST for the period of the trap deployment was $4.9^{\circ} \mathrm{C}$. Thus, using the standard paleoceanographic technique, average sea surface temperature is underestimated by $\sim 2.5^{\circ} \mathrm{C}$.

For a more direct comparison between average synoptic SST and foraminiferal estimates, flux weighted averages of AVHRR SST were calculated. This calculation is applicable since foraminiferal flux was not evenly distributed throughout the year. Thus, synoptic sea surface temperatures for a period were weighted by the percentage of yearly foraminiferal flux that occurred during each period. If the foraminifera were recording SST perfectly, this calculation should give SST as it would be seen in the sediments. The AVHRR SST data was weighted in the following way: the standard 35 day offset was applied to the flux data (so the flux weighting would apply to the proper time period), synoptic SST was then averaged in a 17-day wide window centered on the offset date, and weighted by the appropriate flux percentage. (If $90 \%$ of the yearly flux was captured at yearday 302 , the flux weighted SST for this period would be the average SST from yeardays 250-284 multiplied by 0.90.) Due to the differing distribution of planktonic foraminiferal species during the year, each species yields a different flux weighted average SST. Weighting by the N. pachyderma (l) flux gives an average synoptic SST of $7.70^{\circ} \mathrm{C}$, whereas weighting by G. bulloides flux gives an average of $8.85^{\circ} \mathrm{C}$. One effect of the early summer versus fall bloom assemblage difference is evident from these calculations: G. bulloides has a major bloom once per year, during the warmer fall bloom, biasing the temperature estimate towards the warmer end. For N. pachyderma (l) the early summer bloom pulls the estimate towards the cooler end.

Comparing the flux-weighted foraminiferal estimates of average temperature (what the sediment record will show) to flux weighted average synoptic SST record (what the sediment record would show, given perfect 
recording of SST), shows that the flux-weighted foraminifera records, or the "sediment record," underestimate SST by $5.33^{\circ} \mathrm{C}$ or $6.56^{\circ} \mathrm{C}, \mathrm{N}$. pachyderma (l) and G. bulloides, respectively. It is notable that SST is underestimated not only by the stable isotope record, but by the coiling ratio of N. pachyderma, as well. Coincidentally, the underestimation from the N. pachyderma (l) flux weighted average of SST $\left(5.33^{\circ}\right.$ cold) is similar to the underestimation of maximum seasonal SST using the left-to-right coiling ratio of $N$. pachyderma $\left(\sim 5^{\circ}\right.$ cold $)$.

\section{$\underline{\text { Size/Mass - Isotopic Analysis }}$}

\section{$\underline{\text { Results - Size/Mass }}$}

Size/mass-stable isotope analysis was performed on forty samples of $N$. pachyderma (l) and G. bulloides from the $150-250 \mu \mathrm{m}$ size fraction of the yearday 302 sample collection cup. Data from these analyses are found in Appendices C and D. Average mass for N. pachyderma (1) shells was $5.9 \pm 0.8 \mu \mathrm{g}(1 \sigma)$ (calculated as total isotopic sample weight/number of shells. G. bulloides average mass was $7.8 \pm 0.9 \mu \mathrm{g}(1 \sigma)$. Average maximum axis length (calculated as the average of digitized maximum axis lengths for shells within the sample) was $250.5 \pm 20.3 \mu \mathrm{m}(1 \sigma)$ for $N$. pachyderma $(\mathrm{l})$, and $289.4 \pm 22.4(1 \sigma)$ for $G$. bulloides. Average $\delta^{18} \mathrm{O}$ and $\delta^{13} \mathrm{C}$ values for this study were, respectively, $1.44 \pm 0.21 \%$ and $0.92 \pm 0.12 \%$ for $N$. pachyderma $(1)$, and $2.26 \pm 0.22 \%$ and $-0.18 \pm 0.14 \%$ for G. bulloides.

The $N$. pachyderma (1) samples show clear covariances between all variables, with $\mathrm{r}^{2}$ values as high as 0.74 (Figure 28, Table 4). $\delta^{18} \mathrm{O}$ measurements show negative correlations with both average shell mass and average maximum axis length, with larger and heavier foraminifera having 
lighter $\delta^{18} \mathrm{O}$ values (Figures 28a, b). The opposite is true for $\delta^{13} \mathrm{C}$, with the larger foraminifera having heavier $\delta^{13} \mathrm{C}$ values (Figures 28c, 28d). These $\delta^{18} \mathrm{O}$ and $\delta^{13} \mathrm{C}$ versus size/mass relationships suggest that larger individuals are living shallower in the water column, in warmer (lower $\delta^{18} \mathrm{O}$ ), more nutrient depleted (higher $\delta^{13} \mathrm{C}$ ) water (Figure 28f).

Table 4 Size/mass-isotopic analysis correlation coefficients

\begin{tabular}{|c|l|}
\hline & $\mathrm{r}^{2}$ \\
\hline \hline N. pachyderma (l) axis length -mass & 0.72 \\
\hline$\delta^{18} \mathrm{O}$ - axis length & 0.70 \\
\hline$\delta^{18} \mathrm{O}$ - mass & 0.47 \\
\hline$\delta^{13} \mathrm{C}$ - axis length & 0.67 \\
\hline$\delta^{13} \mathrm{C}$ - mass & 0.47 \\
\hline$\delta^{18} \mathrm{O}-\delta^{13} \mathrm{C}$ & 0.74 \\
\hline axis length -mass & 0.07 \\
\hline$\delta^{18} \mathrm{O}$ - axis length & 0.24 \\
\hline$\delta^{18} \mathrm{O}$ - mass & 0.00 \\
\hline$\delta^{13} \mathrm{C}$ - axis length & 0.06 \\
\hline$\delta^{13} \mathrm{C}-$ mass & 0.30 \\
\hline$\delta^{18} \mathrm{O}-\delta^{13} \mathrm{C}$ & 0.19 \\
\hline
\end{tabular}

Performing the same analyses on G. bulloides shows no clear relationship between any variables (Figure 29, Table 4). There is no clear relationship between average maximum axis length and mass $\left(\mathrm{r}^{2}=0.07\right.$, Figure 29e). Ranges of $\delta^{18} \mathrm{O}$ and $\delta^{13} \mathrm{C}$ values are essentially constant over all masses and shell lengths (Figures 29a-d). As in the yearlong time series, there is no clear relationship between $\delta^{18} \mathrm{O}$ and $\delta^{13} \mathrm{C}$ values (Figure 29f).

\section{Discussion - Size/Mass}


Previous studies have shown increasing $\delta^{18} \mathrm{O}$ and $\delta^{13} \mathrm{C}$ with increasing size in N. pachyderma (1) (Donner \& Wefer, 1994; Keigwin \& Boyle, 1989; Sautter \& Thunell, 1991). Keigwin and Boyle (1989) see $\delta^{18} \mathrm{O}$ increases on the order of $0.1 \%$ between the $150-180$ and $180-250 \mu \mathrm{m}$ size fractions; Donner and Wefer (1994) see the same magnitude $\Delta \delta^{18} \mathrm{O}$ increase between $125-250$ and 250$325 \mathrm{~m}$ size fractions. $\delta^{13} \mathrm{C}$ increases are less well constrained: for the same size fractions as above, Keigwin and Boyle (1989) see $\Delta \delta^{13} \mathrm{C}$ ranging between $0.0 \%$ and $0.2 \%$, Donner and Wefer (1994) see a $\Delta \delta^{13} C \approx 0.2 \%$. Sautter and Thunell (1991) report the direction of observed trends within their $180-212 \mu \mathrm{m}$ size fraction, but not the magnitude of the changes. The $\delta^{13} \mathrm{C}$ change seen in the Sea of Okhotsk $N$. pachyderma (1) has the same trend as previous work, but the magnitude is much greater with a $\Delta \delta^{13} \mathrm{C} \approx 0.6 \%$ over a $100 \mu \mathrm{m}$ size range. The observed $\Delta \delta^{18} \mathrm{O}$ has the opposite sense of previous work, with a $\Delta \delta^{18} \mathrm{O}$ of $-1.0 \%$, tightly correlated to size.

The trends observed in the N. pachyderma (l) size/mass-isotopic analysis are consistent with a population which is in isotopic equilibrium with its environment. The $\delta^{18} \mathrm{O}$ - and $\delta^{13} \mathrm{C}$ - size and mass relationships suggest that larger individuals live shallower in the water column. This sizedepth relationship has been seen in plankton tows from the Arctic Ocean which document larger, more heavily calcified N. pachyderma (l) living shallower than the smaller uncrusted individuals (Carstens \& Wefer, 1992). One potential explanation for this phenomenon in the Sea of Okhotsk is the distribution of food supply: Zenkevitch (1963) shows $90 \%$ of the biomass concentrated in the upper 50 meters of the water column, but $74 \%$ of total biomass is in the upper 25 meters. Laboratory work of Bé et al. (1981) has shown that foraminiferal shell size is highly correlated with food supply; the more frequently a foraminifer is fed, the larger it grows before gametogenesis. 
Based on these size-isotopic trends for N. pachyderma (1), the results of this Sea of Okhotsk study indicate that larger N. pachyderma (1) come closer to reflecting surface conditions than smaller individuals. The calculated change in calcification depths is not great, on the order of 10-20 meters, but in areas with highly stratified water columns, this depth differential can create a large change in both oxygen and carbon isotopes.

The lack of coherent trends in the G. bulloides size/mass-isotope analysis runs counter to the findings of Curry and Matthews (1981), Sautter and Thunell (1991), Kroon and Darling (1995) and Spero and Lea (in press), all of whom find increasing $\delta^{18} \mathrm{O}$ and $\delta^{13} \mathrm{C}$ values with size. The lack of correlation in the $\delta^{18} \mathrm{O}$-size and $\delta^{18} \mathrm{O}$-mass relationships suggests no size- or mass-related preferred depth habitat, as is suggested by the N. pachyderma (l) data. The lack of trends is not solely a function of the small range of sizes measured here, as Spero and Lea (in press) find a $\Delta \delta^{18} \mathrm{O} \approx 0.2 \%$ and a $\Delta \delta^{13} \mathrm{C} \approx$ $0.4 \%$ between average shell sizes of 180 and $237 \mu \mathrm{m}$.

One potential explanation for this lack of trends is the ontogenetic stage of the G. bulloides measured. Coretop work of Curry and Matthews (1981) suggests that larger G. bulloides individuals are closer to isotopic equilibrium than smaller individuals. Laboratory work of Spero and Lea (in press) has refined this observation, demonstrating that the more chambers an individual G. bulloides has, the closer to isotopic equilibrium it is. Figure $\mathbf{1 3}$ shows the flux of G. bulloides broken down by size fraction. For yearday 302, only $28 \%$ of the flux is in the $150-250 \mu \mathrm{m}$ size fraction, the remaining $72 \%$ is in the $>250 \mu \mathrm{m}$ fraction. (The $150-250 \mu \mathrm{m}$ fraction was chosen for this size/massisotopic analysis to enable comparison with the yearlong time series; during winter and spring there were no G. bulloides in the $>250 \mu \mathrm{m}$ fraction.) The foraminifera in the $150-250 \mu \mathrm{m}$ size fraction are not the largest individuals seen in the yearday 302 sample. Thus, it is likely that they are not the most 
ontogenetically advanced (i.e. highest number of chambers) population. Based on the work of Curry and Matthews (1981) and Spero and Lea (in press), we might expect this $150-250 \mu \mathrm{m}$ population to be in disequilibrium.

Spero and Lea (in press) calculate isotopic ontogenetic corrections based on the number of chambers in the G. bulloides shell. They give an average size range of $296 \pm 25 \mu \mathrm{m}$ for 11-chambered individuals; the Sea of Okhotsk $G$. bulloides average $289.4 \pm 22.4 \mu \mathrm{m}$. Applying the 11-chamber "corrections" to the G. bulloides yearday 302 data moves the average $\delta^{18} \mathrm{O}$ value from $2.26 \%$ to $3.00 \%$, and the average $\delta^{13} \mathrm{C}$ value from $-0.18 \%$ to $1.59 \%$. Prior to correction, the average G. bulloides $\delta^{18} \mathrm{O}$ values were $0.82 \%$ heavier than the $N$. pachyderma (1) values. Applying the $\delta^{18} \mathrm{O}$ correction moves G. bulloides $\delta^{18} \mathrm{O}$ values farther out of correspondence with $N$. pachyderma (l) values, making the $\Delta \delta^{18} \mathrm{O}_{\text {bull-pachy }} \approx 1.5 \%$. It also moves $\delta^{18} \mathrm{O}$-calculated calcification depths into the dichothermal layer. Applying the $\delta^{13} \mathrm{C}$ correction moves average G. bulloides $\delta^{13} \mathrm{C}$ closer to that for $N$. pachyderma (l): $\delta^{13} C_{\text {bull corrected }}=1.59 \%, \delta^{13} C_{\text {pachy-1 }}=0.92 \%$. This $\delta^{13} \mathrm{C}$ correction also moves the $\delta^{13} \mathrm{C}$-calculated depths for G. bulloides up to approximately 15 meters water depth (35 day offset applied for this comparison). It is possible that the Sea of Okhotsk samples were not 11-chambered, and this is not the appropriate "correction", however, all the Spero and Lea corrections have the same sense and would move the $\delta^{18} \mathrm{O}$-calculated calcification depths deeper and the $\delta^{13} \mathrm{C}$-calculated depths shallower. Based on food availability, it is unlikely that G. bulloides inhabits the dichothermal layer. This suggests that Spero and Lea's $\delta^{18} \mathrm{O}$ correction may not be appropriate for Sea of Okhotsk G. bulloides specimens, as application of this correction moves $\delta^{18} \mathrm{O}$-calculated calcification depths into this cold layer. The $\delta^{13} \mathrm{C}$ correction, however, may be more applicable, as this correction moves $\delta^{13} \mathrm{C}$-calculated calcification depths from the dichothermal layer into shallow waters. 


\section{Summary}

The planktonic foraminiferal population of the Sea of Okhotsk is dominated by two species: N. pachyderma (left) and G. bulloides, with $57 \%$ and $33 \%$ of total yearly foraminiferal flux, respectively. The occurrence of the polar species $N$. pachyderma (l) with the warmer water G. bulloides is unusual. This combination of species is most likely due to the high seasonality of the Sea of Okhotsk, where synoptic sea surface temperatures varied from -1.2 to $14.8^{\circ} \mathrm{C}$ during the trap deployment. Despite the high SST's seen in summer, however, the left-to-right coiling ratio of N. pachyderma was never less than $98 \%$ (Figure 14). These coiling ratios would indicate maximum seasonal temperatures no greater than $10^{\circ} \mathrm{C}$, considerably colder than actual maximum sea surface temperature.

The stable isotope record is consistent with these $N$. pachyderma coiling ratios: the temperatures at calcification depths (from $\delta^{18} \mathrm{O}_{\text {foram }}$ and $\delta^{18} \mathrm{O}_{\text {eq. calcite) }}$ are $<10^{\circ} \mathrm{C}$. In the summer, both $N$. pachyderma (l) and $G$. bulloides appear to calcify between 20 and 40 meters water depth (Figures 24 and 24). At these depths within the highly stratified water column of the Sea of Okhotsk, foraminifera experience temperatures much colder than SST. Both species appear to follow a preferred temperature range, from $2^{\circ}$ to $7^{\circ} \mathrm{C}$ for $N$. pachyderma (l) and $0.5^{\circ}$ to $5^{\circ} \mathrm{C}$ for G. bulloides (Figure 27). There is a seasonal $\delta^{18} \mathrm{O}$ signal seen for both species, but the amplitude is much damped from what might be expected if the foraminifera were living at the sea surface (Figures 23 and 24). In the winter, $\delta^{18} \mathrm{O}$ values for both species are lighter than those calculated for the water column, suggesting a holdover population from the fall bloom, or an imported population. 
Carbon isotopic measurements show a clear seasonal signal for $N$. pachyderma (1) (Figure 18). The yearlong time series $\delta^{13} C_{\text {pachy-1 }}$ record follows the yearly productivity cycle, but again appears to be damped, in accordance with calcification depths. N. pachyderma (l) calcification depths from $\delta^{13} \mathrm{C}_{\text {eq. calcite }}$ are 25 to 45 meters water depth (Figure 26), similar to those calculated from oxygen isotopes. Carbon isotopes in G. bulloides do not exhibit a clear seasonal cycle (Figure 19). $\delta^{13} C_{\text {bull }}$ is significantly lighter than $\delta^{13} C_{\text {pachy-1; }}$ apparent calcification depths are correspondingly deeper

(Figure 25).

The close correspondence between $\delta^{18} \mathrm{O}$ - and $\delta^{13} \mathrm{C}$-calculated calcification depths, and the linear relationship between $\delta^{18} \mathrm{O}$ and $\delta^{13} \mathrm{C}$ for $N$. pachyderma (l) samples (Figure 20) suggests that this species calcifies close to or in isotopic equilibrium with its environment. Size/mass-isotopic analysis indicates that larger N. pachyderma (l) individuals are closer to (but not reaching) expected sea surface isotopic composition. There is no clear relationship between $\delta^{18} \mathrm{O}, \delta^{13} \mathrm{C}$, and size for G. bulloides.

\section{Implications}

The results from this study show that the two commonly used paleoceanographic proxies for sea surface temperature may underestimate SST by as much as $5^{\circ} \mathrm{C}$ in a highly stratified water column. The use of the $N$. pachyderma left-to-right coiling ratio would underestimate maximum seasonal SST by $\sim 5^{\circ} \mathrm{C}$ at this location. The yearly average temperature calculated from $\delta^{18} \mathrm{O}$ of $G$. bulloides and N. pachyderma (l) is $2.5^{\circ} \mathrm{C}$ too low, if no accounting is made for the seasonality of planktonic foraminiferal flux. If this seasonality of production is taken into consideration when calculating the average synoptic SST, the estimate is as much as $7^{\circ}$ to $8^{\circ} \mathrm{C}$ low. These 
offsets are of the same magnitude as sea surface temperature changes believed to be characteristic of Dansgaard-Oeschger events and other such millennial scale climate oscillations (e.g. Bond et al., 1993; Lehman \& Keigwin, 1992).

These temperature offsets appear to be a function of foraminiferal calcification depth. $\delta^{18} \mathrm{O}$ and $\delta^{13} \mathrm{C}$ measurements of $N$. pachyderma $(\mathrm{l})$ and $\delta^{18} \mathrm{O}$ measurements of $\mathrm{G}$. bulloides indicate calcification between $\sim 30-40$ meters water depth, where ambient temperatures are significantly lower $\left(\sim 5^{\circ} \mathrm{C}\right)$ than surface waters. The full reason for this choice of calcification depth is not presently understood. Availability of food is certainly a factor for these non-symbiotic foraminiferal species, as indicated by the work of Ortiz et al. (1995), and Fairbanks et al. (1982). This study and the work of Sautter and Thunell (1991) also suggest preferred temperature ranges as a possibility, making calcification depth strongly dependent on shallow water column hydrography. Unlike a constant vital effect, which can simply be subtracted from downcore data, food availability and shallow hydrography are not easily quantified downcore. Changes in calcification depth due to variations in these two factors will be difficult, at best, to identify and correct for.

In a less highly stratified region, a calcification depth of 30-40 meters would not be expected to create such a large underestimation of SST. There are several lines of evidence, however, that suggest that we might expect high-latitude glacial oceans to be highly stratified, like the Sea of Okhotsk. First, diatom and radiolarian assemblages suggest that modern Sea of Okhotsk conditions are similar to high-latitude glacial oceans (Morley \& Hays, 1983; Sancetta \& Silvestri, 1986). Second, modeling results have shown that the presence of the dichothermal layer and the resultant surface water stratification in the Sea of Okhotsk is strongly tied to the amount of fresh water input, driven particularly by fresh sea ice meltwater (Yang \& Honjo, in press). Other present day instances of dichothermal layers in the Bering Sea 
and Southern Ocean appear to be linked to the presence of sea ice (Honjo et al., 1995, in press). The CLIMAP (1976) SST reconstruction shows greatly expanded sea ice extents in high latitudes; fresh water from seasonal sea ice melt may be expected to have a correspondingly larger effect. Thus this kind of highly stratified water column may be typical of high latitude oceans during glaciations.

There is evidence for sea-ice melt stratification effects on foraminiferal calcification depths and oxygen isotopes in both modern and downcore records. In the Greenland Sea, Johannessen et al. (1994) find their highest $\delta^{18} \mathrm{O}$ values in coretop samples of $\mathrm{N}$. pachyderma (l) overlain by seasonally open waters (i.e. seasonally free of ice). They see $\delta^{18} \mathrm{O}$ values $\sim 0.5 \%$ heavier than ice-free regions. Plankton tow work of Kohfeld (pers. commun., 1995) shows N. pachyderma (l) individuals living deeper at the Greenland Sea ice edge than in the ice-free Norwegian Sea. At calcification depth, the Greenland Sea specimens experience waters around $-1^{\circ} \mathrm{C}$, as opposed to surface water temperatures of $\sim 3^{\circ} \mathrm{C}$. Downcore work of Karpuz and Jansen (1992) in the Norwegian Sea (HM 79-6; 62 $58^{\prime} \mathrm{N}, 02^{\circ} 42^{\prime} \mathrm{E}$ ) shows a period of heavy $\delta^{18} \mathrm{O}_{\text {pachy-1 }}$ between $12.0-12.3 \mathrm{kyBP}$ associated with marginal ice zone flora. For another period rich in marginal ice zone flora (11.5-11.8 kyBP), $\delta^{18} \mathrm{O}_{\text {pachy-1 }}$ oscillates between heavy and light values. A nearby core (HM 52$\left.43 ; 64^{\circ} 31^{\prime} \mathrm{N}, 00^{\circ} 44^{\prime} \mathrm{E}\right)$, however, shows a $\delta^{18} \mathrm{O}_{\text {pachy-l }}$ excursion of $0.75 \%$ towards heavier $\delta^{18} \mathrm{O}$ values during the same time period (Sarnthein et al., 1992). In addition, Karpuz and Jansen find discrepancies between diatom assemblage and N. pachyderma (l) based temperature estimates, particularly between 6.5-5.0 kyBP, with foraminiferal estimates being significantly lower. It is not unreasonable to think that the high seasonality they suggest as a potential cause for this difference might also be linked to a highly stratified upper water column. 
The results of this Sea of Okhotsk study suggest that N. pachyderma (1) calcify in equilibrium with the $\delta^{13} \mathrm{C}$ of ambient seawater. This finding has bearing on one of the ongoing questions of paleoceanography: the discrepancy between the nutrient proxies $\delta^{13} \mathrm{C}$ and $\mathrm{Cd} / \mathrm{Ca}$ from $\mathrm{N}$. pachyderma (l) in surface waters during the last glacial maximum (LGM). $\delta^{13} \mathrm{C}$ records show LGM surface waters in the North Atlantic and the Southern Ocean anywhere between 0.5 and $1.0 \%$ lighter in $\delta^{13} \mathrm{C}$ than modern values (Charles \& Fairbanks, 1990; Keigwin \& Boyle, 1989). When the terrestrial biosphere effect on mean ocean $\delta^{13} \mathrm{C}$ is taken into effect (-0.3\% for LGM, Curry, et al., 1988), this change becomes smaller, but still exists. The suggestion that $N$.

pachyderma (1) is in carbon isotopic equilibrium suggests that perhaps the LGM $\delta^{13} \mathrm{C}$ records using this planktonic foraminiferal species are correct. This debate is not definitively closed: the discrepancy between the measured $\delta^{13} \mathrm{C}$ of $N$. pachyderma (1) and expected values seen by Keigwin and Boyle (1989) still represents a problem. A true resolution may wait until a comparison is made between the present $\delta^{13} \mathrm{C}$ measurements from this trap, and $\mathrm{Cd} / \mathrm{Ca}$ measurements. 


\section{$\underline{\text { References }}$}

Anderson, O. R., Spindler, M., Bé, A. W. H., \& Hemleben, C. (1979). Trophic Activity of Planktonic Foraminifera. I. mar. Biol. Ass. U.K., 59, 791799.

Bé, A. W. H. (1977). An Ecological, Zoogeographic and Taxonomic Review of Recent Planktonic Foraminifera. In A. T. S. Ramsay (Ed.), Oceanic Micropaleontology, Volume 1, (Vol. 1, pp. 1-100). London: Academic Press.

Bé, A. W. H., Caron, D. A., \& Anderson, O. R. (1981). Effects of feeding frequency on life processes of the planktonic foraminifer Globigerinoides sacculifer in laboratory culture. I. mar. biol. Ass. U.K., 61, 257-277.

Bé, A. W. H., \& Tolderlund, D. S. (1971). Distribution and Ecology of Living Planktonic Foraminifera in Surface Waters of the Atlantic and Indian Oceans. In B. M. Funnell \& W. R. Riedel (Eds.), The Micropaleontology of Oceans, (pp. 105-149). Cambridge: Cambridge University Press.

Berger, W. H. (1969). Ecologic patterns of living planktonic Foraminifera. Deep-Sea Research, 16(1), 1-24.

Bond, G., Broecker, W., Johnsen, S., McManus, J., Labeyrie, L., Jouzel, J., \& Bonani, B. (1993). Correlations between climate records from North Atlantic sediments and Greenland ice. Nature, 365, 143-147.

Bradshaw, J. S. (1959). Ecology of Living Planktonic Foraminifera in the North and Equatorial Pacific Ocean. Contrib. Cushman. Found. Foram. Res., 10(2), 25-64.

Broecker, W. S., \& Peng, T.-H. (1982). Tracers in the Sea. Palisades, New York: ELDIGIO Press.

Caron, D. A., \& Swanberg, N. R. (1990). The Ecology of Planktonic Sarcodines. Aquatic Sciences, 3(1\&2), 147-180. 
Carstens, J., \& Wefer, G. (1992). Recent distribution of planktonic foraminifera in the Nansen Basin, Arctic Ocean. Deep-Sea Research, 39(Suppl. 2), S507-S524.

Cavalieri, D. J., \& Parkinson, C. L. (1987). On the Relationship Between Atmospheric Circulation and the Fluctuations in the Sea Ice Extents of the Bering and Okhotsk Seas. Lournal of Geophysical Research, 92(C7), 7141-7162.

Charles, C. D., \& Fairbanks, R. G. (1990). Glacial to interglacial changes in the isotopic gradients of Southern Ocean surface water. In U. Bleil \& J. Thiede (Eds.), Geological History of the Polar Oceans: Arctic vs. Antarctic, (pp. 519-538). Boston, Mass.: Kluwer Academic Publishers.

CLIMAP. (1976). The Surface of the Ice-Age Earth - quantitative geologic evidence is used to reconstruct boundary conditions of the climate 18,000 years ago. Science, 191(4232), 1131-1137.

Curry, W. B., Duplessy, J.-C., Labeyrie, L. D., \& Shackleton, N. J. (1988). Changes in the distribution of $\delta^{13} \mathrm{C}$ of deep water $\Sigma \mathrm{CO}_{2}$ between the last glaciation and the Holocene. Paleoceanography, 3(3), 317-341.

Curry, W. B., \& Matthews, R. K. (1981). Equilibrium ${ }^{18}$ O fractionation in small size fraction planktic foraminifera: Evidence from recent Indian Ocean sediments. Marine Micropaleontology, 6, 327-337.

Curry, W. B., Ostermann, D. R., Guptha, M. V. S., \& Ittekkot, V. (1992). Foraminiferal production and monsoonal upwelling in the Arabian Sea: evidence from sediment traps. In C. P. Summerhays, W.L. Prell, \& K.C. Emeis (Ed.), Upwelling Systems: Evolution Since the Early Miocene, (pp. 93-106): Geological Society Special Publication, No. 64.

Dodimead, A. J., Favorite, F., \& Hirano, T. (1963). Salmon of the North Pacific Ocean, Part II: Review of Oceanography of the Subarctic Pacific Region : International North Pacific Fisheries Commission.

Donner, B., \& Wefer, G. (1994). Flux and stable isotope coinposition of Neogloboquadrina pachyderma and other planktonic foraminifers in the Southern Ocean (Atlantic sector). Deep Sea Research, 41(11/12), 1733-1743. 
Ericson, D. B. (1959). Coiling Direction of Globigerina pachyderma as a Climatic Index. Science, 130, 219-220.

Fairbanks, R. G., Sverdlove, M., Free, R., Wiebe, P. H., \& Bé, A. W. H. (1982). Vertical distribution and isotopic fractionation of living planktonic foraminifera from the Panama Basin. Nature, 298, 841-844.

Gowing, M. M. (1989). Abundance and feeding ecology of Antarctic phaeodarian radiolarians. Marine Biology, 103, 107-118.

Grossman, E. L. (1982). Stable isotopes in live benthic foraminifera from the Southern California Borderland. Ph.D. thesis, University of Southern California, Los Angeles.

Honjo, S. (1984). Study of Ocean Fluxes in Time and Space by BottomTethered Sediment Trap Arrays: A Recommendation. Global Ocean Flux Study, Proceedings of a Workshop, National Academy Press, Washington DC.

Honjo, S., \& Doherty, K. W. (1988). Large aperture time-series sediment traps; design objectives, construction and application. Deep-Sea Research. 35(1), 133-149.

Honjo, S., Honda, M., Manganini, S., \& Ishii, H. (1995, in press). Biogeochemical Cycles in the Sea of Okhotsk, a temporarily ice-bound large marginal sea. Deep-Sea Research (in press).

Honjo, S., \& Manganini, S. J. (1993). Annual biogenic particle fluxes to the interior of the North Atlantic Ocean; studied at $34^{\circ} \mathrm{N} 21^{\circ} \mathrm{W}$, and $48^{\circ} \mathrm{N}$ $21^{\circ} \mathrm{W}$. Deep-Sea Research, 40(1/2), 587-607.

Honjo, S., \& Manganini, S. J. (unpublished). Station Papa flux: data report from a four-year sediment trap deployment series.

Hut, G. (1987, ). Consultant's group meeting on Stable Isotope Reference Samples for Geochemical and Hydrological Investigations. Paper presented at the International Atomic Energy Agency.

Johannessen, T., Jansen, E., Flatøy, A., \& Ravelo, A. C. (1994). The Relationship Between Surface Water Masses, Oceanographic Fronts and Paleoclimatic Proxies in Surface Sediments of the Greenland, Iceland, 
Norwegian Seas. In R. Zahn \& e. al (Eds.), Carbon Cycling in the Glacial Ocean: Constraints on the Ocean's Role in Global Change, (Vol. I-17, pp. 6185). Berlin: Springer-Verlag.

Kahn, M. I., \& Williams, D. F. (1981). Oxygen and carbon isotopic composition of living planktonic foraminifera from the northeast Pacific Ocean. Paleogeog., Paleoclim., Paleoecol., 33, 47-69.

Karpuz, N. K., \& Jansen, E. (1992). A High-Resolutions Diatom Record of the Last Deglaciations from the SE Norwegian Sea: Documentation of Rapid Climatic Changes. Paleoceanography, 7(4), 499-520.

Keigwin, L. D., \& Boyle, E. A. (1989). Late Quaternary Paleochemistry of high-latitude surface waters. Paleogeog., Paleoclim., Paleoecol., 73, 85-106.

Kellogg, T. B. (1973). Late Quaternary Climatic Changes in the Norwegian and Greenland Seas. In G. Weller \& S. A. Bowling (Eds.), Climate of the Arctic, . 24th Alaska Science Conference, August 15-17, 1973; Sponsored by the American Association for the Advancement of Science and the American Meteorological Society: Geophysical Institute, University of Alaska, Fairbanks, Alaska.

Kitani, K. (1973). An oceanographic study of the Okhotsk Sea particularly in regard to cold waters. Bull. Far Seas Fish. Res. Lab., 9 , 45-76.

Kitazato, H. (1978). Distribution of the Globigerina pachyderma (Ehrenberg) in the Kuril and Japan Basins, and the Fluctuation of Coiling Direction of G. pachyderma in the Core P109. In E. Honza (Ed.), Geological Investigation of the Okhotsk and Japan Seas off Hokkaido, June-July 1977 (GH77-3 Cruise), (pp. 56-59, tables). Tokyo: Geological Survey of Japan.

Kroon, D., \& Darling, K. (1995). Size and upwelling control of the stable isotope composition of Neogloboquadrina dutertrei (D'Orbigny), Globigerinoides ruber (D'Orbigny), and Globigerina bulloides (D'Orbigny): Examples from the Panama Basin and the Arabian Sea. Iour. Foram. Res., $\underline{25}(1), 39-52$.

Kroon, D., \& Ganssen, G. (1989). Northern Indian Ocean upwelling cells and the stable isotope composition of living planktonic foraminifers. Deep-Sea Research, 36(8), 1219-1236. 
Labeyrie, L. D., \& Duplessy, J. C. (1985). Changes in the oceanic ${ }^{13} \mathrm{C} /{ }^{12} \mathrm{C}$ ratio during the last 140,000 years: high latitude surface water records. Paleogeog., Paleoclim., Paleoecol., 50, 217-240.

Lee, J. L., McEnery, M., Pierce, S., Freudenthal, H. D., \& Muller, W. A. (1966). Tracer Experiments in Feeding Littoral Foraminifera. I. Protozool., $\underline{13}(4), 659-670$.

Lehman, S. J., \& Keigwin, L. D. (1992). Sudden Changes in North Atlantic circulation during the last deglaciation. Nature, 356, 757-762.

Lipps, J. H., \& Warme, J. E. (1966). Planktonic foraminiferal biofacies in the Okhotsk Sea. Contrib. Cush. Found. Foram. Res., 17(4), 125-134, plate 1.

Morley, J. J., \& Hays, J. D. (1983). Oceanographic conditions associated with high abundances of the radiolarian Cycladophora davisiana. Earth and Planetary Science Letters, 66, 63-72.

O'Neil, J. R., Clayton, R. N., \& Mayeda, T. K. (1969). Oxygen Isotope Fractionation in Divalent Metal Carbonates. Jour. Chem. Phys., 51(12), 55475558 .

Oppo, D. W., \& Lehman, S. J. (1995). Suborbital timescale variability of North Atlantic Deep Water during the past 200,000 years. Paleoceanography, 10(5), 901-910.

Ortiz, J. D., Mix, A. C., \& Collier, R. W. (1995). Environmental control of living symbiotic and asymbiotic foraminifera of the California Current. Paleoceanography, 10(6), 987-1009.

Parkinson, C. L., \& Gratz, A. J. (1983). On the Seasonal Sea Ice Cover of the Sea of Okhotsk. Journal of Geophysical Research, 88(C5), 2793-2802.

Prell, W. L., \& Curry, W. B. (1981). Faunal and isotopic indices of monsoonal upwelling: Western Arabian Sea. Oceanologica Acta, 4(1), 91-98.

Presley, E.A., (1996). Personal Communication. Stop and Shop, aisles 513. 
Sancetta, C., \& Silvestri, S. (1986). Pliocene-Pleistocene Evolution of the North Pacific Ocean-Atmosphere System, Interpreted from Fossil Diatoms. Paleoceanography, 1(2), 163-180.

Sarnthein, M., Jansen, E., Arnold, M., Duplessy, J. C., Erlenkeuser, H., Flatøy, A., Veum, T., Vogelsang, E., \& Weinelt, M. S. (1992). $\delta^{18}$ O time-slice reconstructions of meltwater anomalies at Termination I in the North Atlantic between 50 and $80^{\circ} \mathrm{N}$. In E. Bard \& W. S. Broecker (Eds.), The Last Deglaciation: Absolute and Radiocarbon Chronologies, (Vol. I2, pp. 183-200). Berlin: Springer-Verlag.

Sautter, L. R., \& Thunell, R. C. (1989). Seasonal Succession of Planktonic Foraminifera: Results from a Four Year Time-Series Sediment Trap Experiment in the Northeast Pacific. Iour. Foram. Res., 19(4), 253-267.

Sautter, L. R., \& Thunell, R. C. (1991). Seasonal variability in the $\delta^{18} \mathrm{O}$ and $\delta^{13} \mathrm{C}$ of planktonic foraminifera from an upwelling environment: sediment trap results from the San Pedro Basin, Southern California Bight. Paleoceanography, 6(3), 307-334.

Shackleton, N. J. (1973, ). Attainment of isotopic equilibrium between ocean water and the benthonic foraminifera genus Uvigerina: isotopic changes in the ocean during the last glacial. Paper presented at the Colloques Internationaux du Centre National de la Recherche Scientifique, Gif-surYvette.

Shchedrina, Z. G. (1958). Fauna foraminifer morskikh vod iuzhnogo Sakhalina i iushnykh Kuril'skikh Ostrovov (in Russian). Issled. Dal'nev. Morei SSR., 5(1), 5-41.

Shuntov, V. P., Radchenko, V. I., Chuchukalo, V. I., Efimkin, A. Y., Kuznetsova, N. A., Lapko, V. V., Poltev, Y. N., \& Senchenko, I. A. (1993). Structure of Planktonic and Nektonic Communities in the Upper Epipelagic Zone of the Sakhalin-Kuril Region in the Period of Anadramous Migrations of Salmon. Russian Journal of Marine Biology, 19(4), 240-247.

Smith, E. (1992). A User's Guide to the NOAA Advanced Very High Resolution Radiometer Multichannel Sea Surface Temperature Data Set : The University of Miami - Rosenstiel School of Marine and Atmospheric Science, 
distributed by the Physical Oceanography Distributed Active Archive Center, Jet Propulsion Laboratory, California Institute of Technology.

Spero, H. J., \& Lea, D. W. (in press). Experimental Determination of Stable Isotope Variability in Globigerina bulloides: Implications for Paleoceanographic Reconstructions. Marine Micropaleontology.

Takizawa, T. (1982). Characteristics of the Soya Warm Current in the Okhotsk Sea. Jour. Oceanog. Soc. Japan, 38, 281-292.

Talley, L. D., \& Nagata, Y. (1995). The Okhotsk Sea and Oyashio Region (Report of Working Group 1) (2): North Pacific Marine Science Organization (PICES).

Thunell, R., \& Sautter, L. R. (1992). Planktonic foraminiferal faunal and stable isotopic indices of upwelling: a sediment trap study in the San Pedro Basin, Southern California Bight. In C. P. Summerhayes, W. L. Prell, \& K. C. Emeis (Eds.), Upwelling Systems: Evolution Since the Early Miocene, (Vol. No. 64, pp. 77-91): Geological Society Special Publication.

Thunell, R. C., Pilskaln, C. H., Tappa, E., \& Sautter, L. R. (1994). Temporal variability in sediment fluxes in the San Pedro Basin, Southern California Bight. Continental Shelf Research, 14(4), 333-352.

Volkov, A. F., \& Chuchukalo, V. I. (1985). Mesoplankton composition and distribution in the Okhotsk Sea during spring-summer period (based on the TINRO studies in 1949-1982) (In Russian). IZV.-TINRO, 110, 125-128.

Williams, D. F., Sommer, M. A. I., \& Bender, M. L. (1977). Carbon Isotopic Compositions of Recent Planktonic Foraminifera of the Indian Ocean. Earth and Planetary Science Letters, 36, 391-403.

Wolfteich, C. M. (1994). Satellite-Derived Sea Surface Temperature, Mesoscale Variability, and Foraminiferal Production in the North Atlantic. Masters thesis, MIT-WHOI Joint Program.

Yakunin, L. P. (1993, ). Temperature and salinity of surface waters of the Okhotsk Sea at extremal periods of year. Paper presented at the Eighth International Symposium on Okhotsk Sea and Sea Ice and ISY Polar Ice Extent Workshop, Mombetsu, Japan. 
Yang, J., \& Honjo, S. (in press). Modeling the dichothermal layer at the Sea of Okhotsk. .

Yasuoka, T. (1967). Hydrography in the Okhotsk Sea-(1). The Oceanographical Magazine, 19(1), 61-72.

Yasuoka, T. (1968). Hydrography in the Okhotsk Sea-(2). The Oceanographical Magazine, 20(1), 55-63.

Zenkevitch, L. (1963). The Sea of Okhotsk, Biology of the Seas of the U.S.S.R., (pp. 783-817). New York: Interscience Publishers. 
Figures 


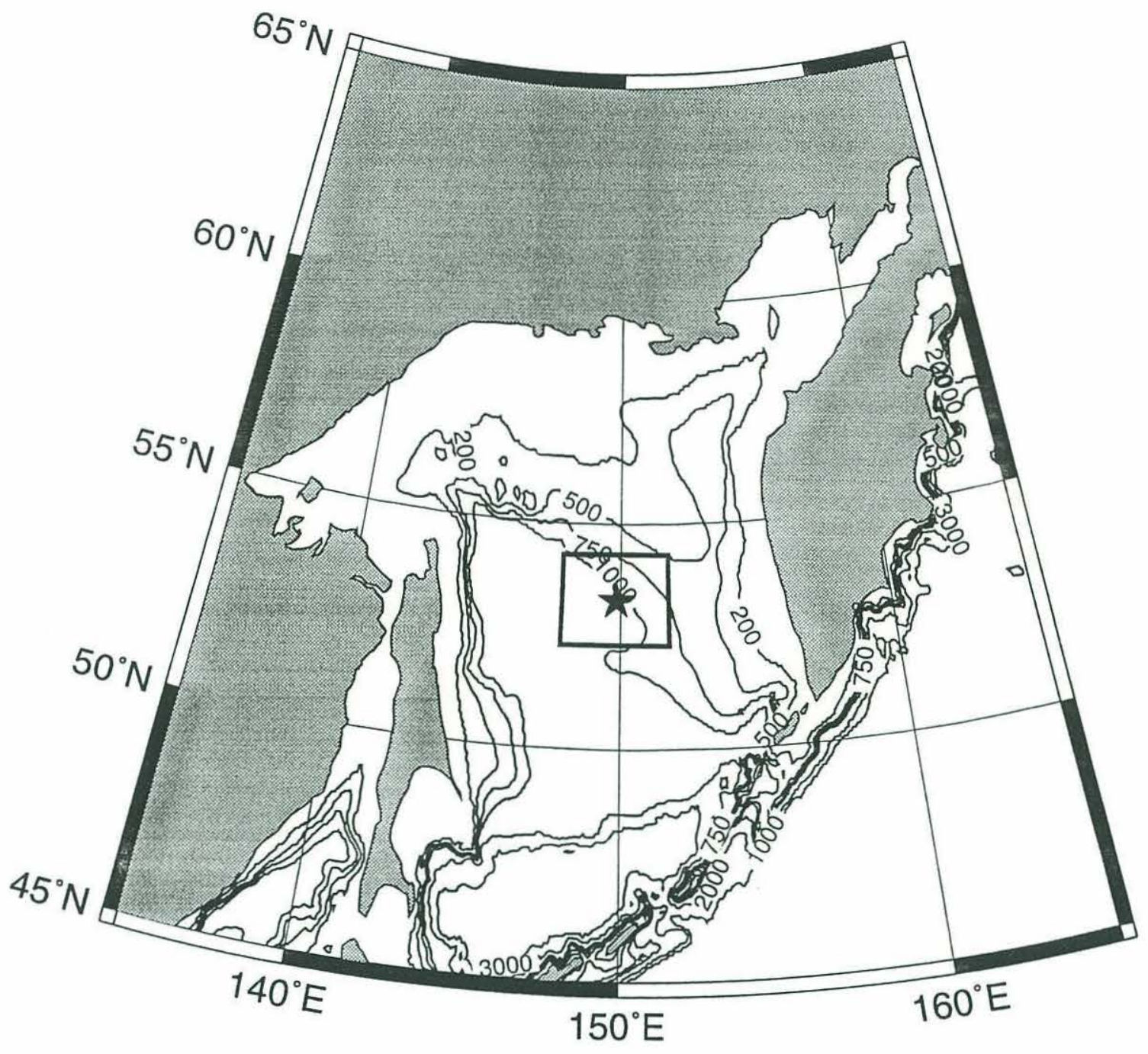

Figure 1 Sea of Okhotsk. Sediment trap deployment site $\left(\$, 53^{\circ} 19 ; \mathrm{N}\right.$, $\left.149^{\circ} 51^{\prime} \mathrm{E}\right)$. Area used for AVHRR MCSST average $\left(52^{\circ} 18^{\prime}-54^{\circ} 18^{\prime} \mathrm{N}, 147^{\circ} 48^{\prime}\right.$ $\left.51^{\circ} 48^{\prime} \mathrm{E}\right)$ marked by box. 


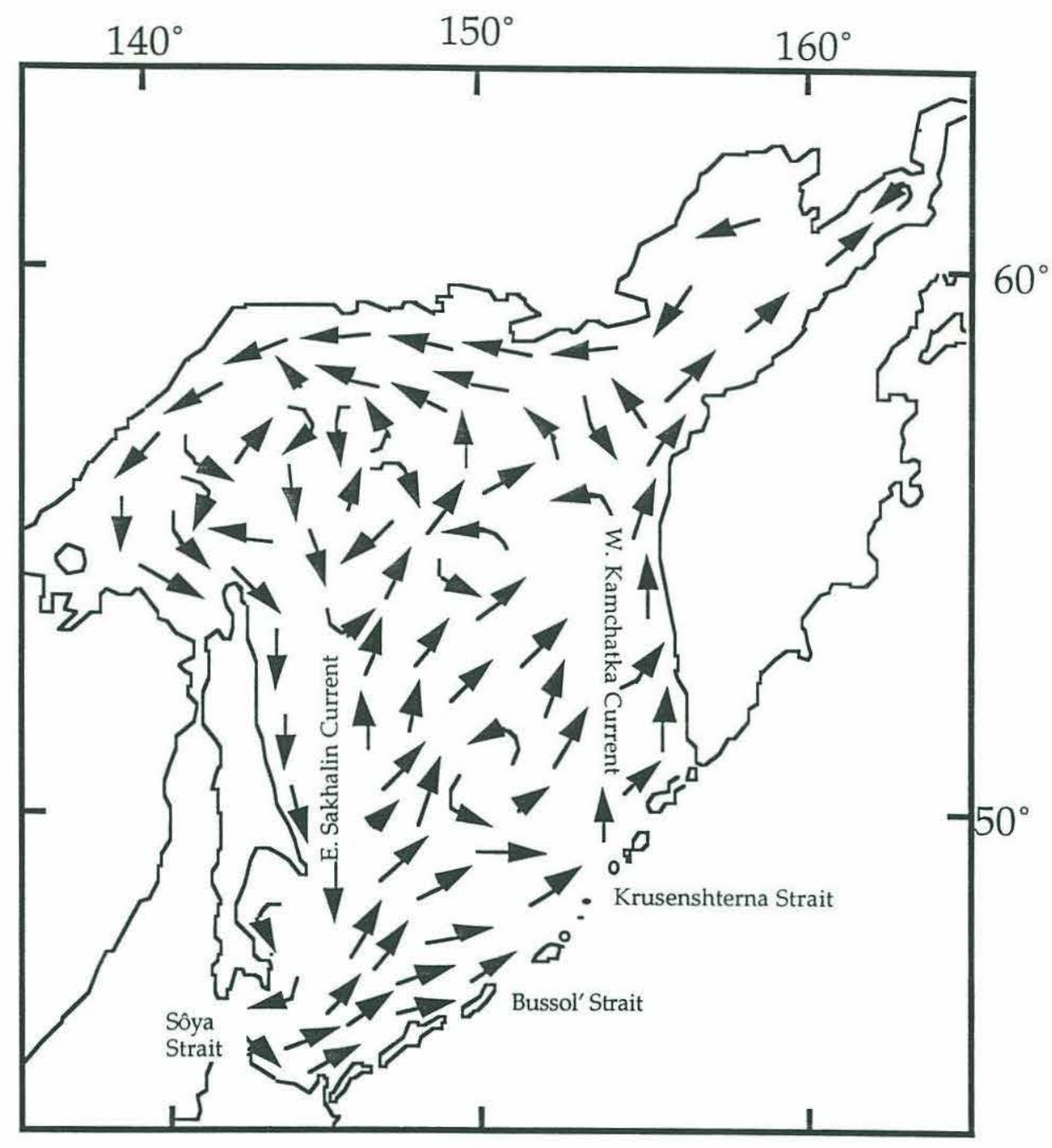

Figure 2 Representative circulation scheme for the Sea of Okhotsk. 


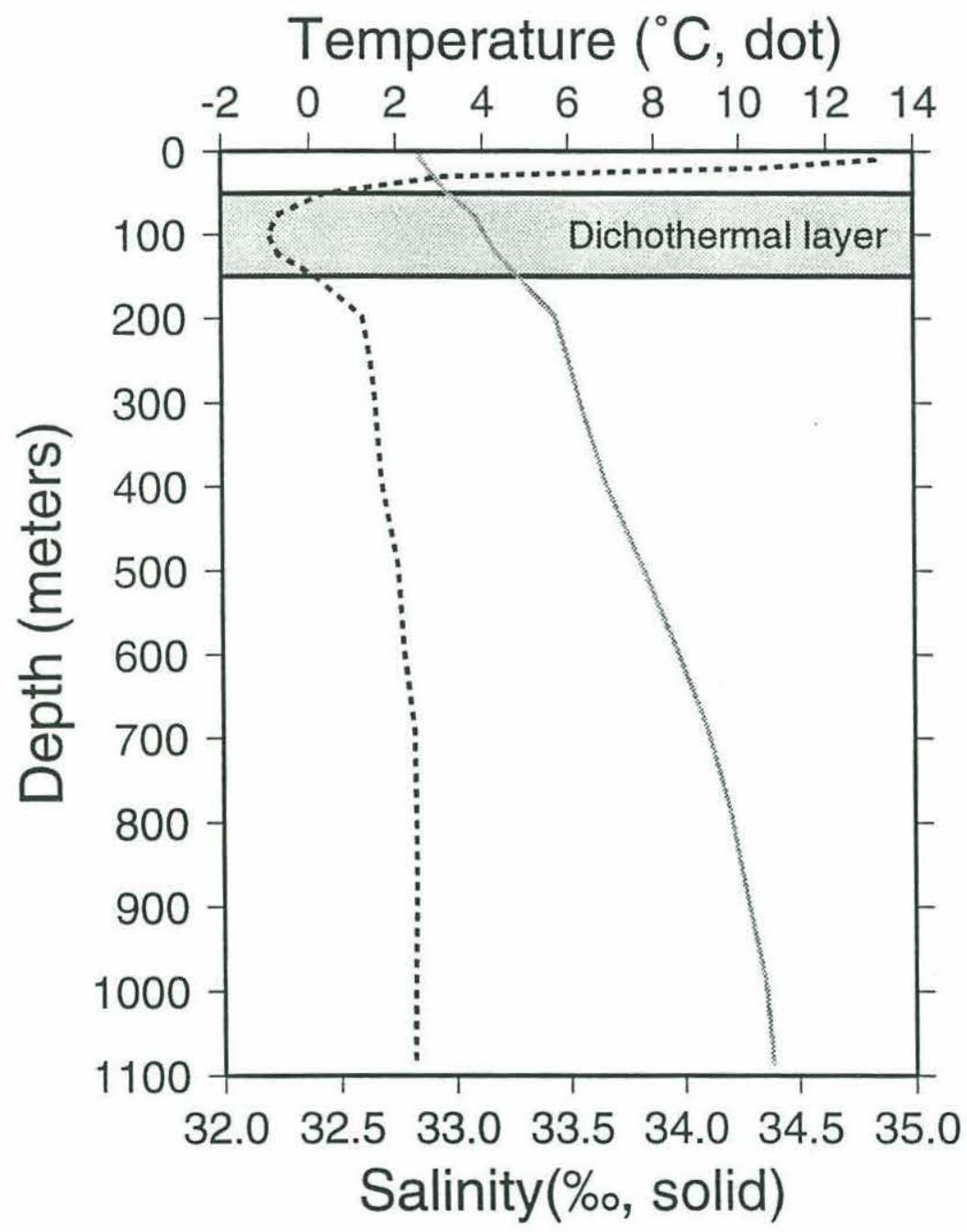

Figure 3 Representative summertime hydrographic profile in the Sea of Okhotsk (August 1990, 53¹8'N, $149^{\circ} 49^{\prime} \mathrm{E}$ ). 


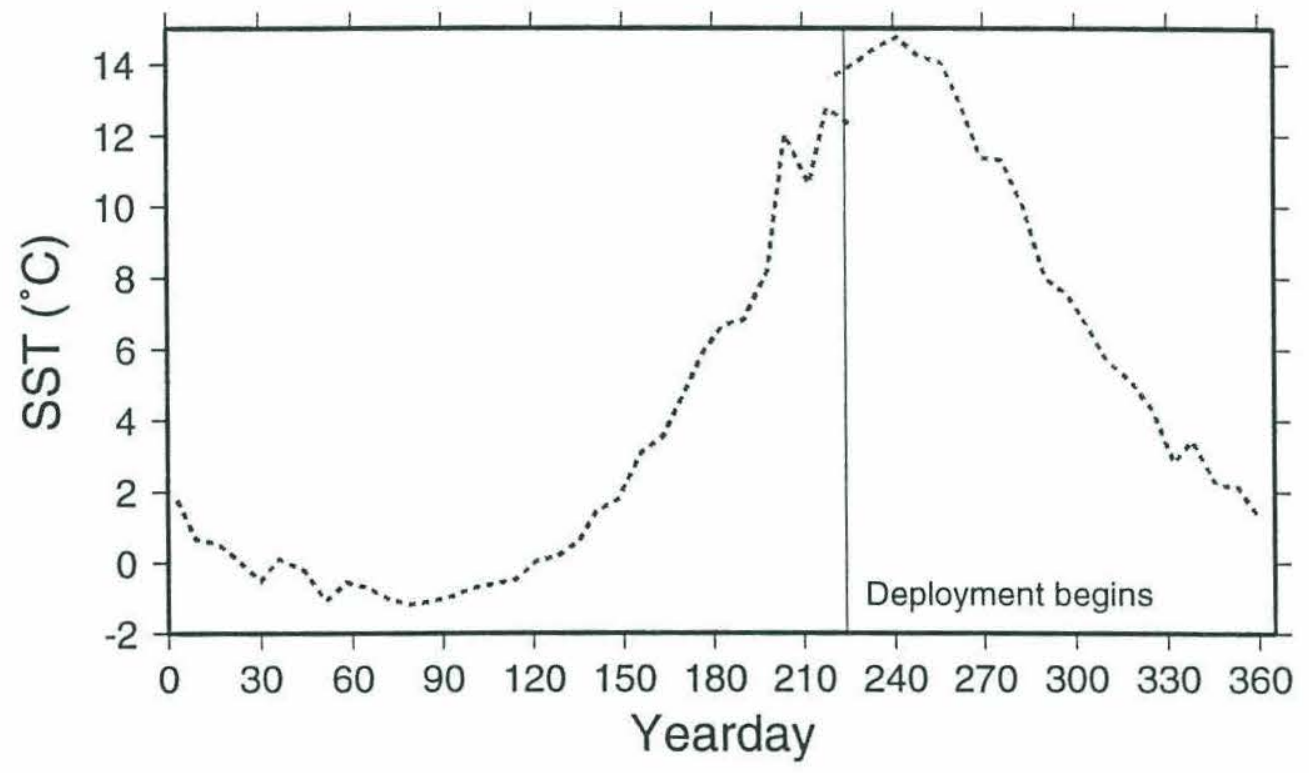

Figure 4 Synoptic sea surface temperature for period of sediment trap deployment, average from AVHRR MCSST. 


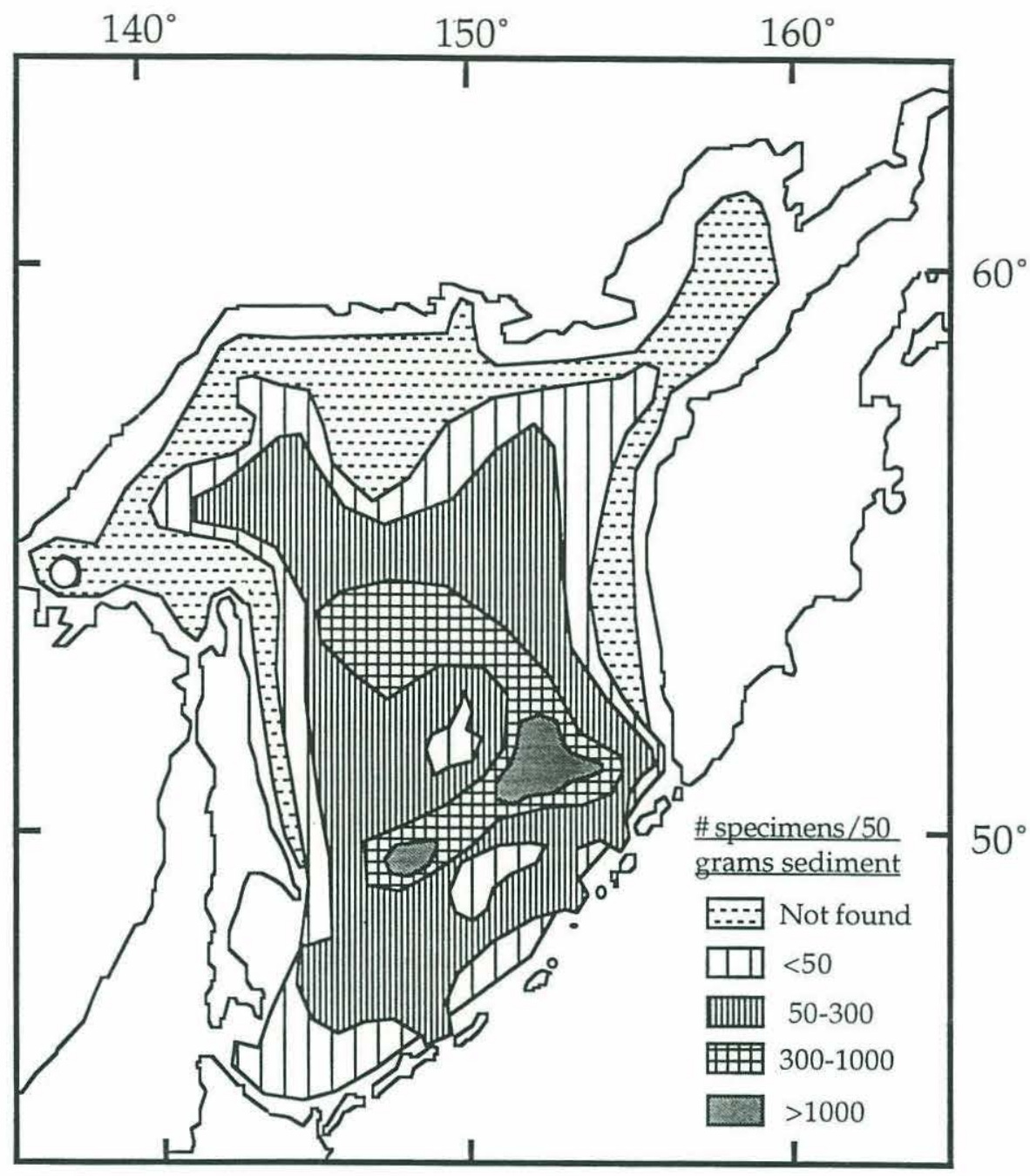

Figure 5 Abundance of planktonic foraminiferal tests per 50 grams of bottom sediments in the Okhotsk Sea (after Lipps \& Warme, 1966). 


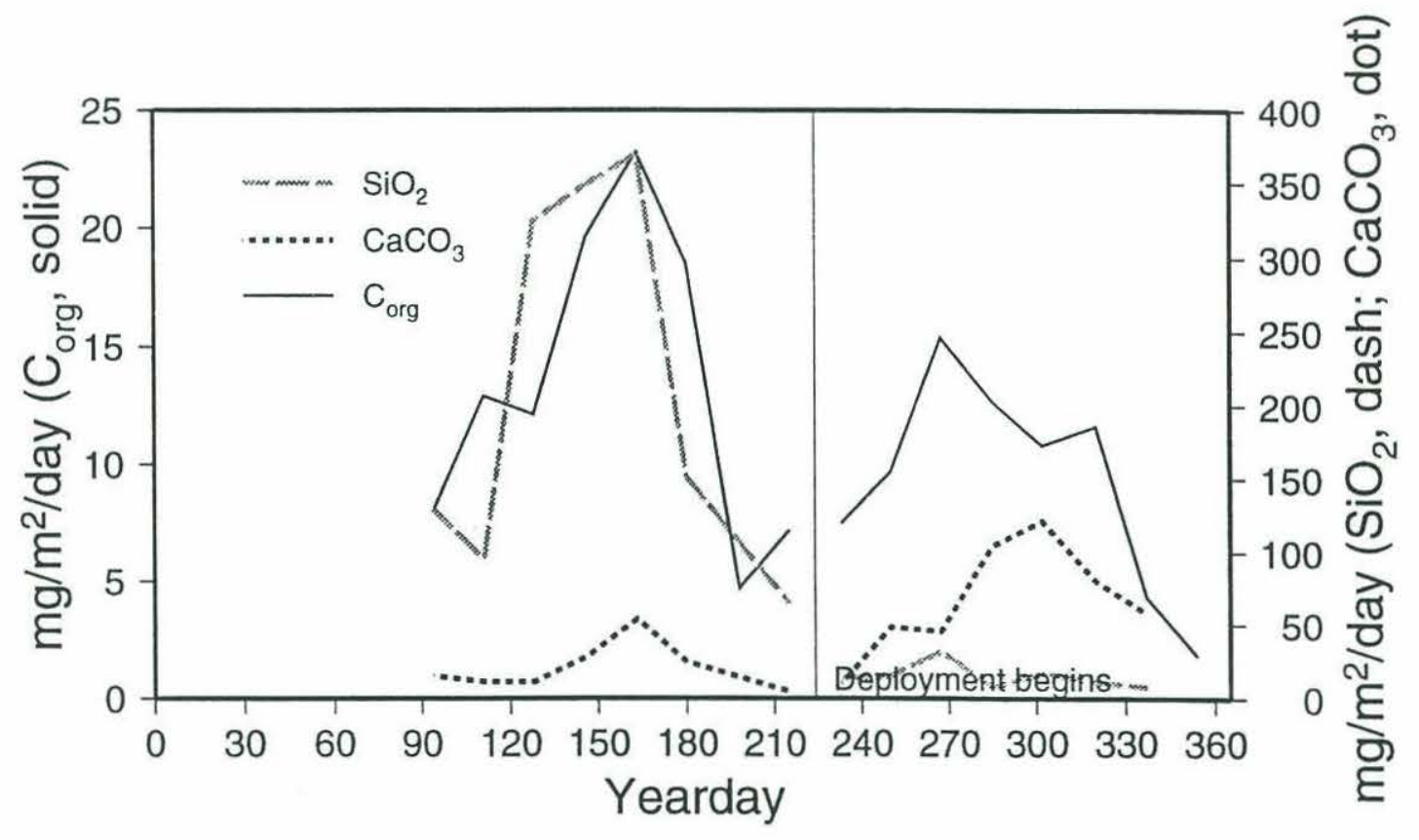

Figure 6 Flux constituent analysis from the sediment trap. Solid line - organic carbon $\left(\mathrm{C}_{\text {org }}\right)$, dashed $-\mathrm{SiO}_{2}$, dotted $-\mathrm{CaCO}_{3}$. 


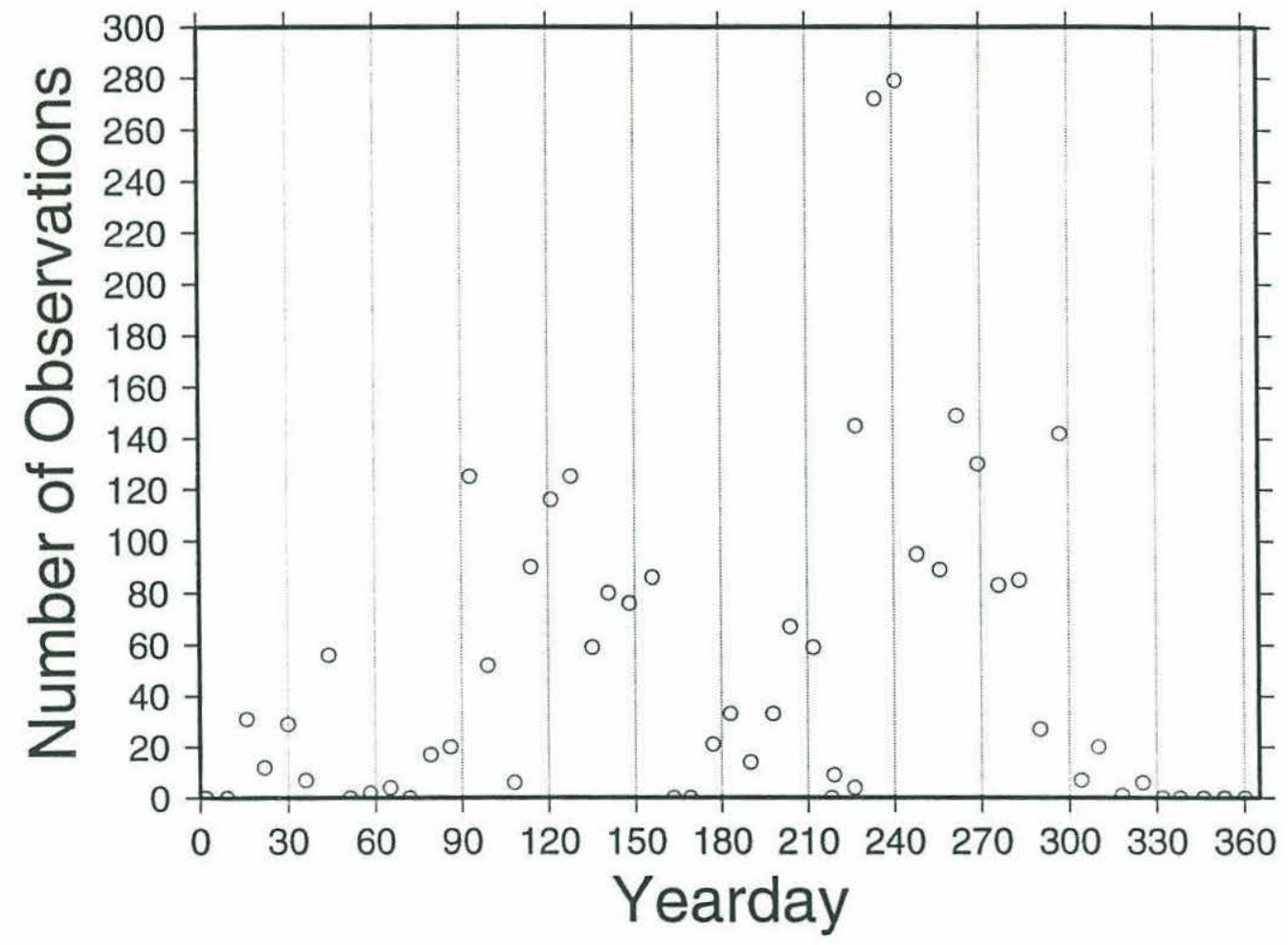

Figure 7 Number of observations per sea surface temperature average value for the trap deployment period. 


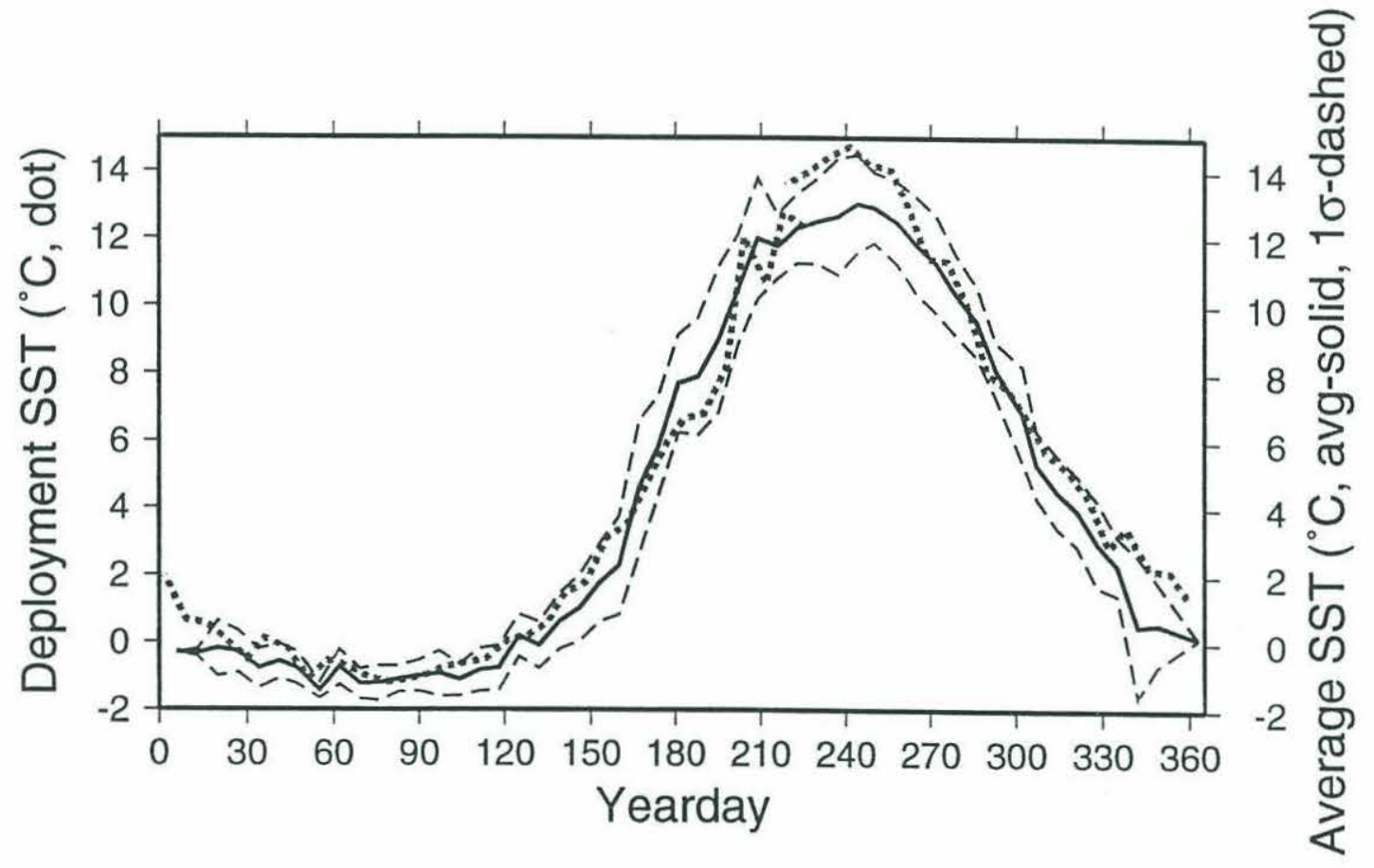

Figure 8 Average deployment SST (dotted) with respect to average and one standard deviation of SST for the ten year period 1982-1992. No interpolated SST values were used in calculating the ten year average and standard deviation. Average deployment period SST is within one standard deviation of the ten year average except for yeardays 210-250, at the yearly iemperature maximum. SST's at this time are not significantly higher. 


\section{Temperature Profile}

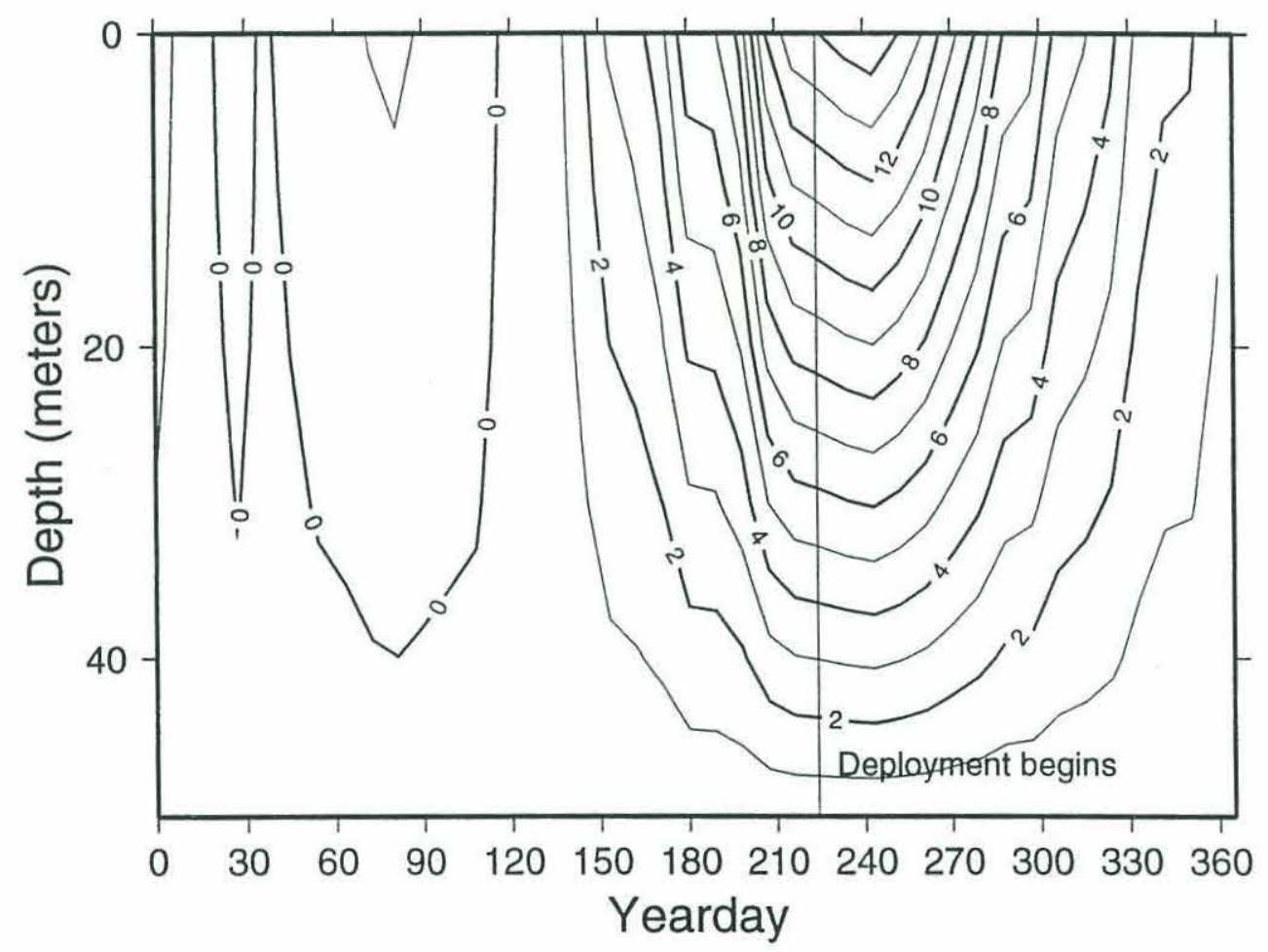

Figure 9 Seasonal temperature profile for the upper 50 meters of the water column calculated using AVHRR MCSST. This is the temperature profile used for equilibrium calcite calculations. 


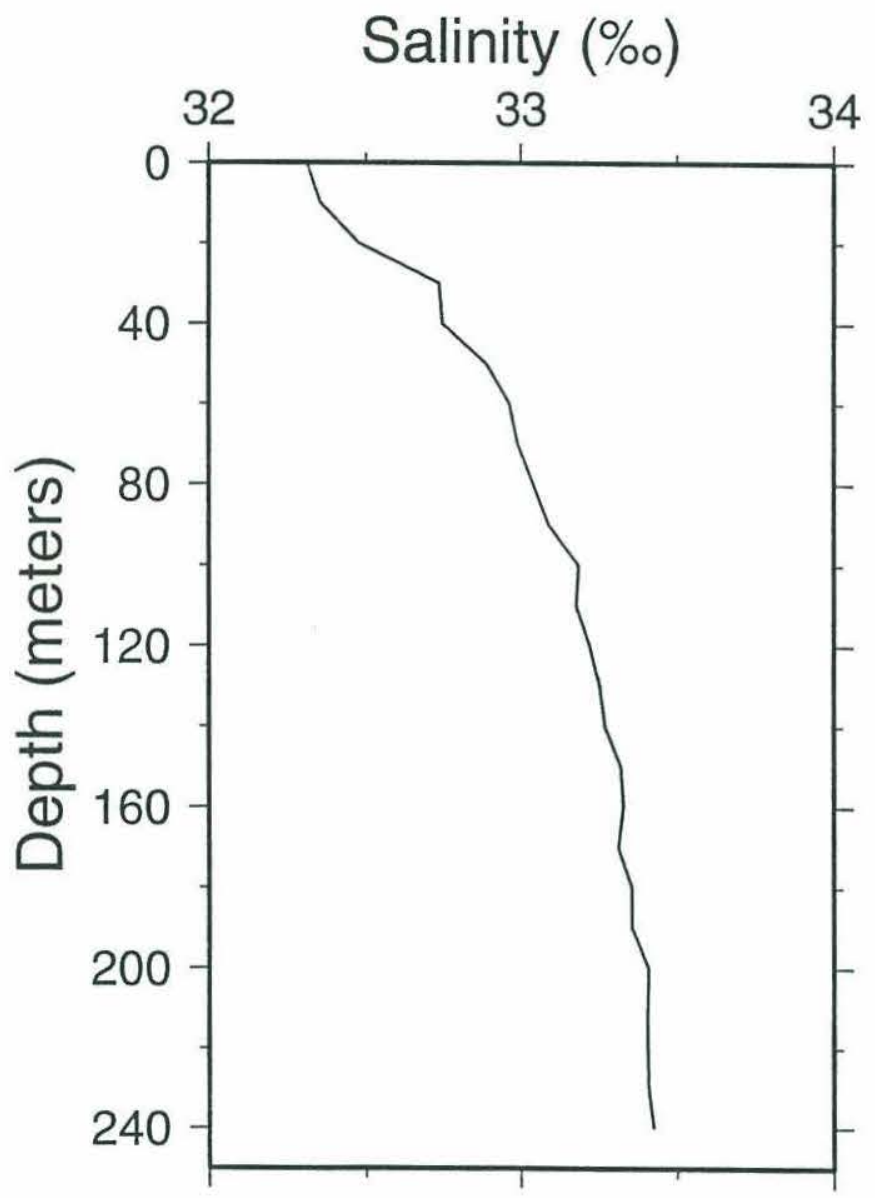

Figure 10 Average salinity profile from NODC data for the trap deployment region $\left(50-55^{\circ} \mathrm{N}, 145-155^{\circ} \mathrm{E}\right)$. This is the salinity profile used for equilibrium calcite calculations. 


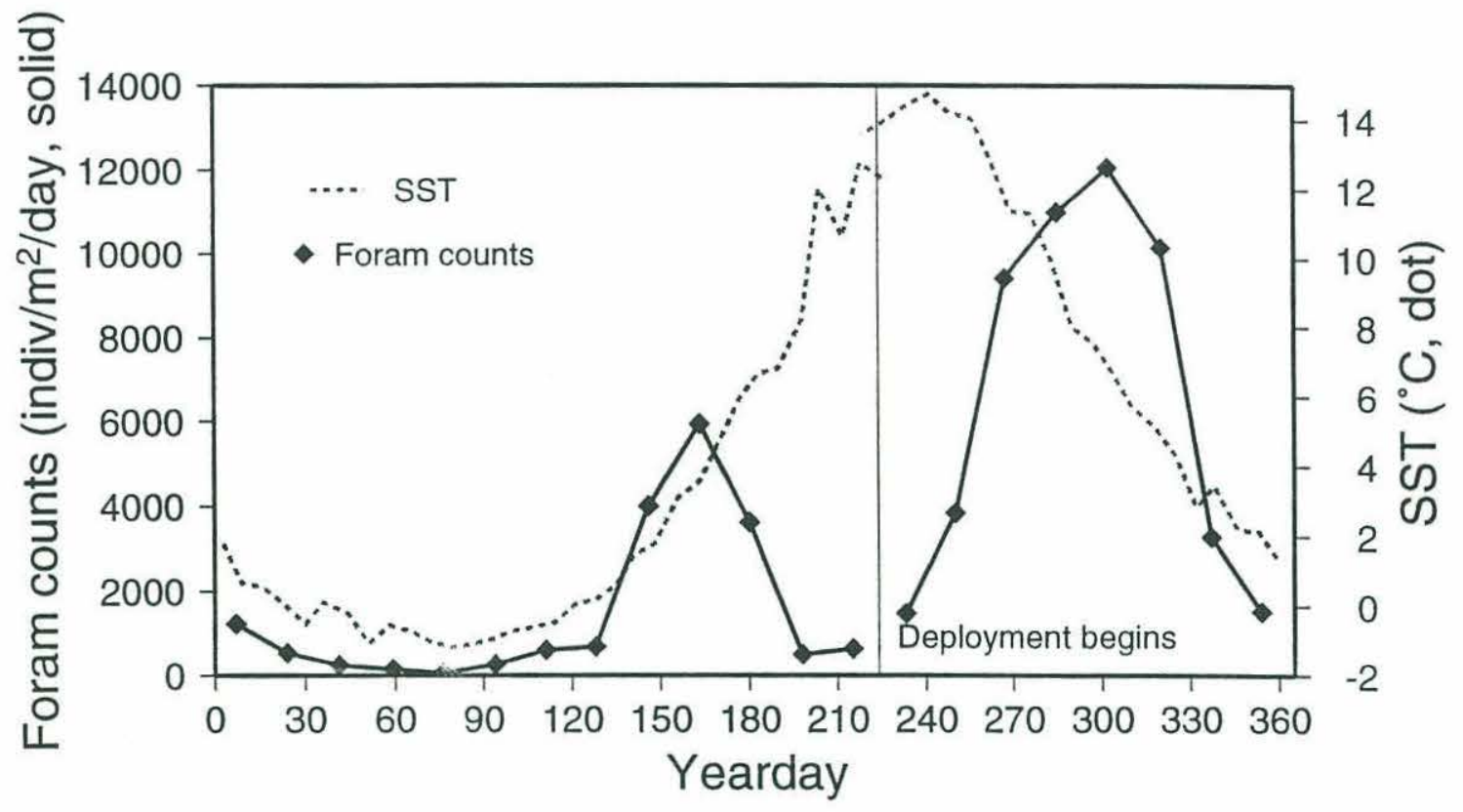

Figure 11 Total planktonic foraminiferal flux ( $>150 \mu \mathrm{m}$ size fraction) versus yearday. Foraminiferal flux shows two blooms: an early summer and a fall bloom. 


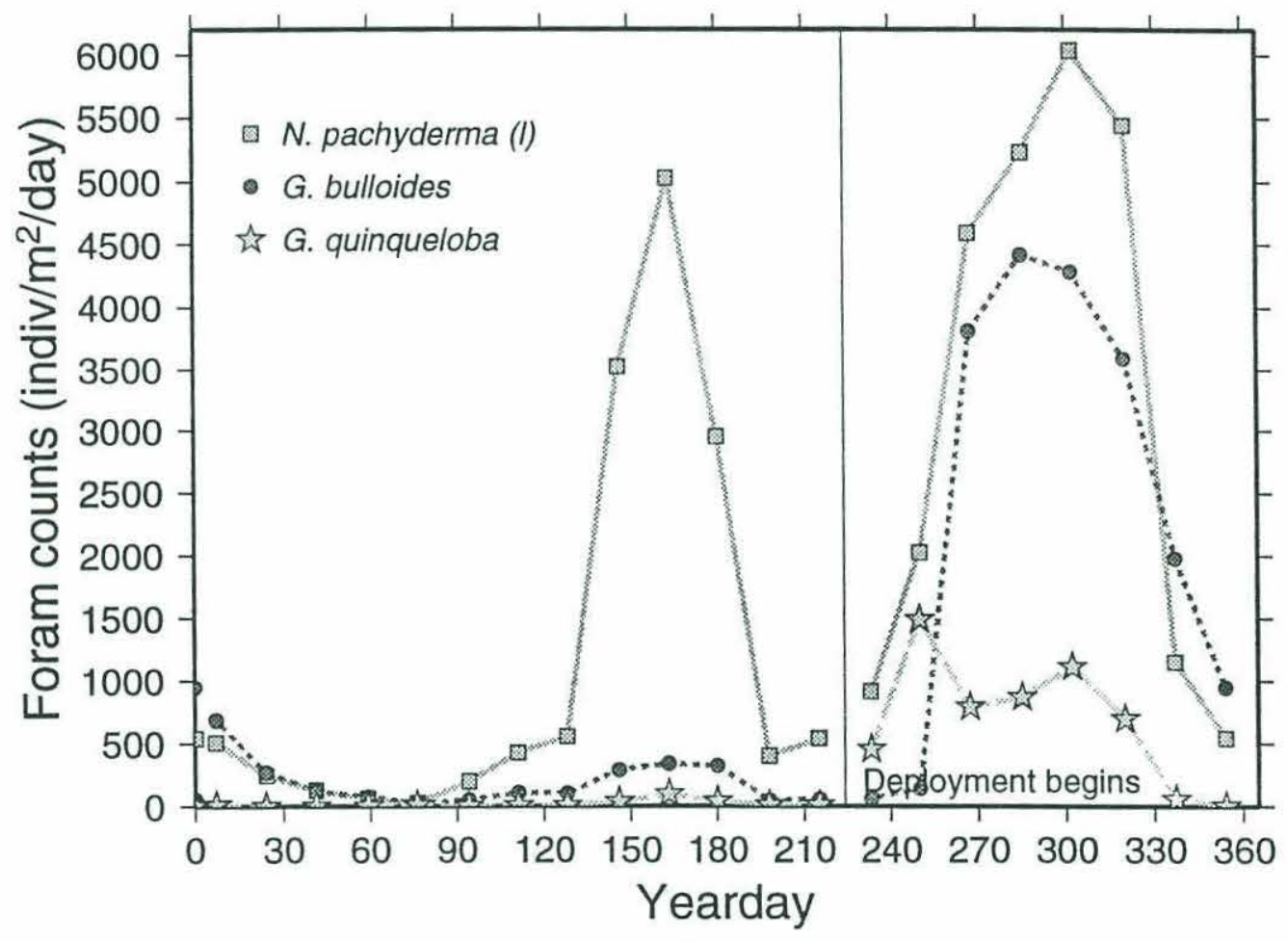

Figure 12 Flux of N. pachyderma (1), G. bulloides, and G. quinqueloba, the three dominant species seen in this sediment trap study. Note: in subsequent figures, N. pachyderma (l) individuals are indicated by squares ( $\square$ ), and $G$. bulloides are indicated by circles $(O)$, as in this figure. 


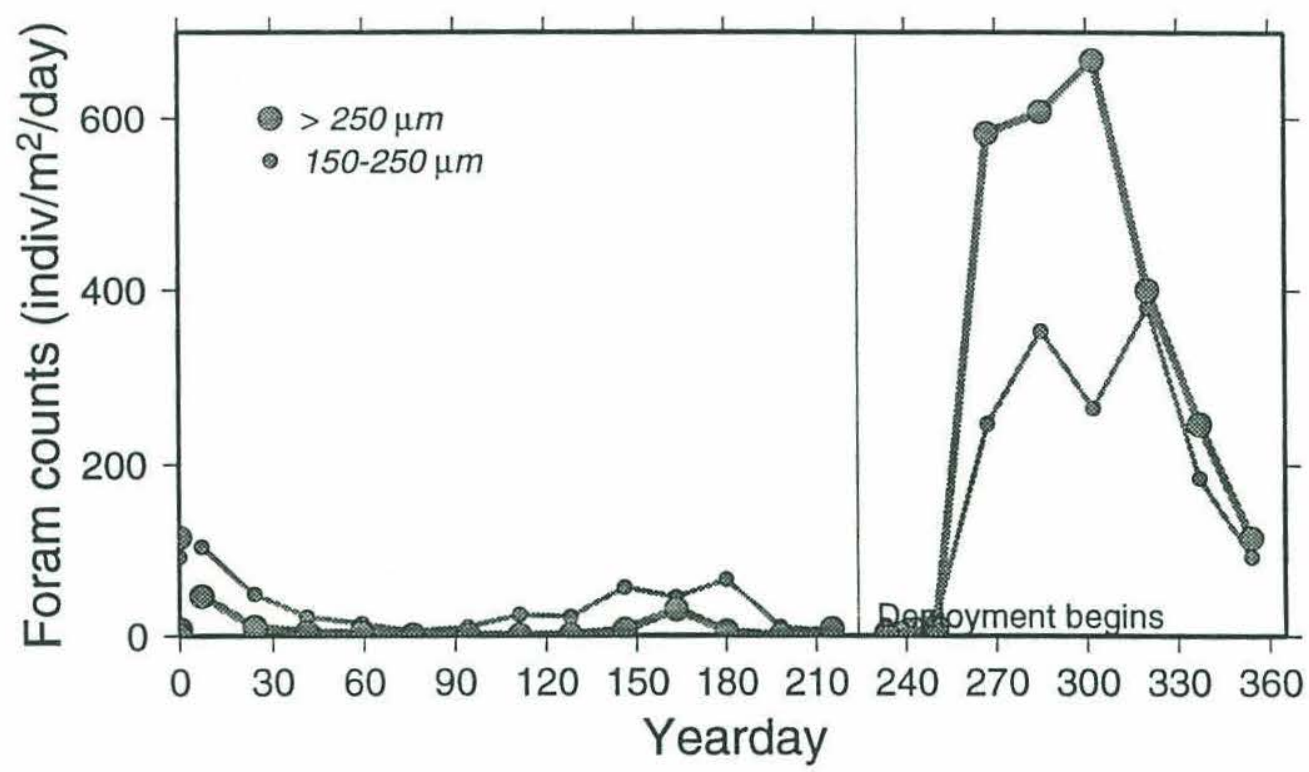

Figure 13 G. bulloides flux broken down into $150-250 \mu \mathrm{m}$ and $>250 \mu \mathrm{m}$ size fractions. 


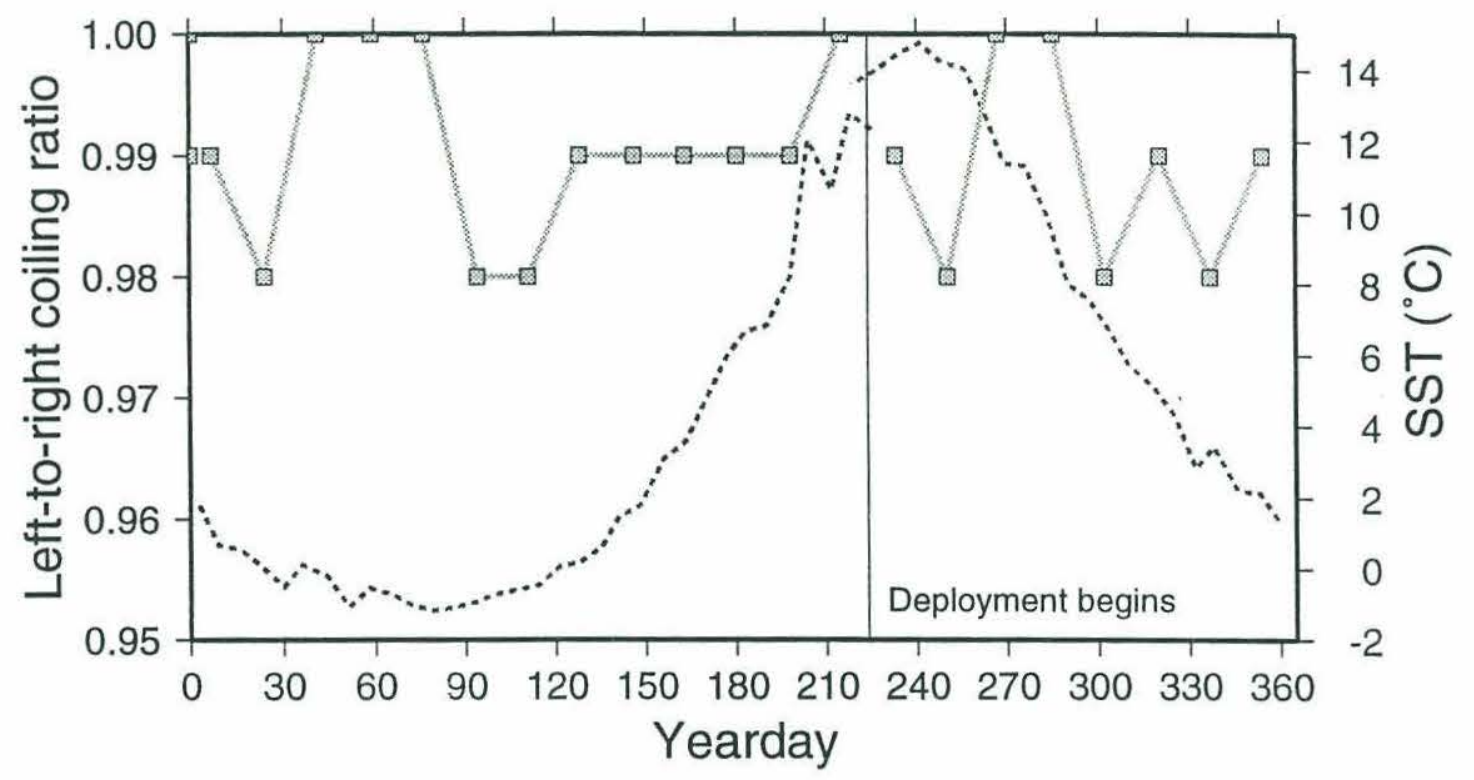

Figure $14 N$. pachyderma (l) left-to-right coiling ratio versus synoptic SST. Note that the coiling ratio never goes below $98 \%$. 


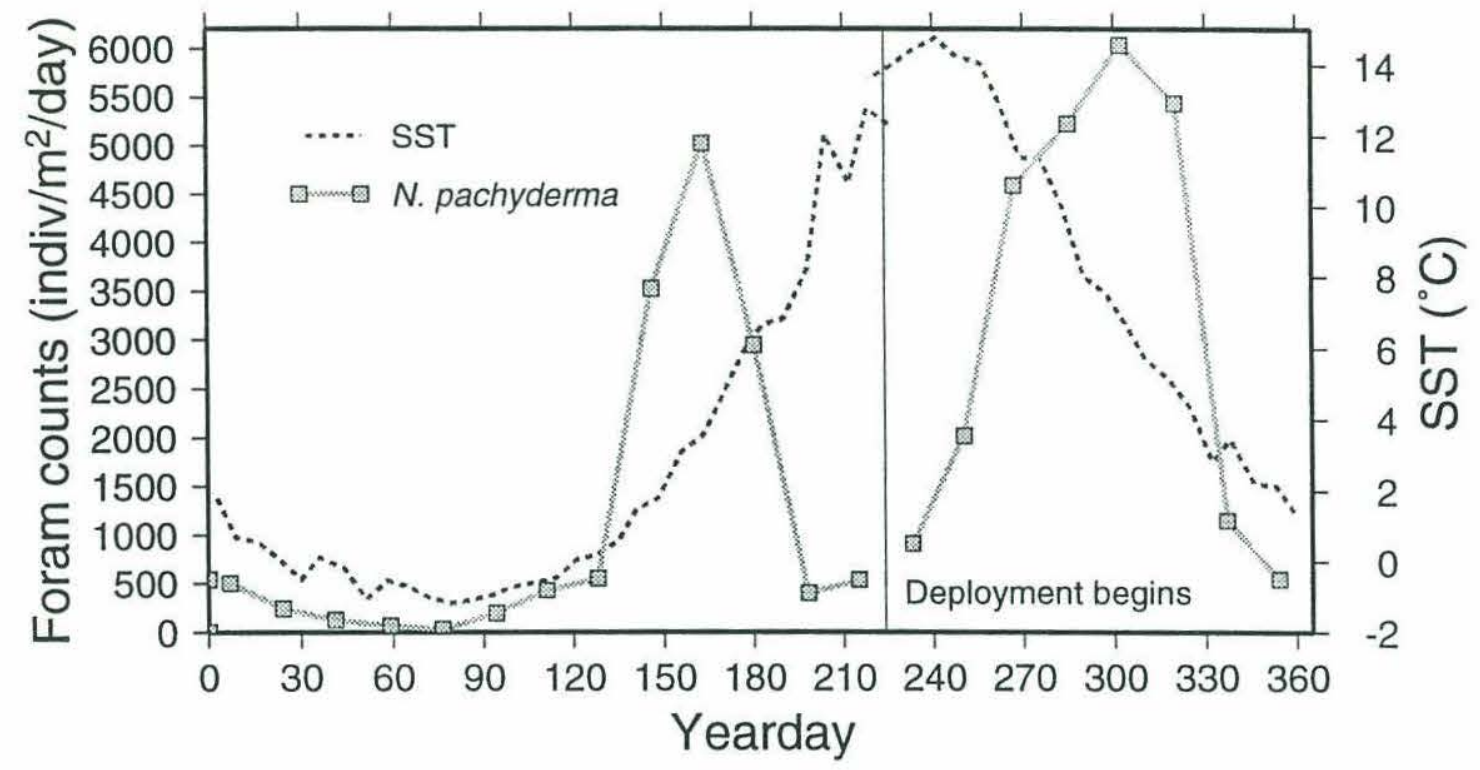

Figure 15 Flux of N. pachyderma (1) versus synoptic SST. Note high fluxes during warm SST periods. 
N. pachyderma

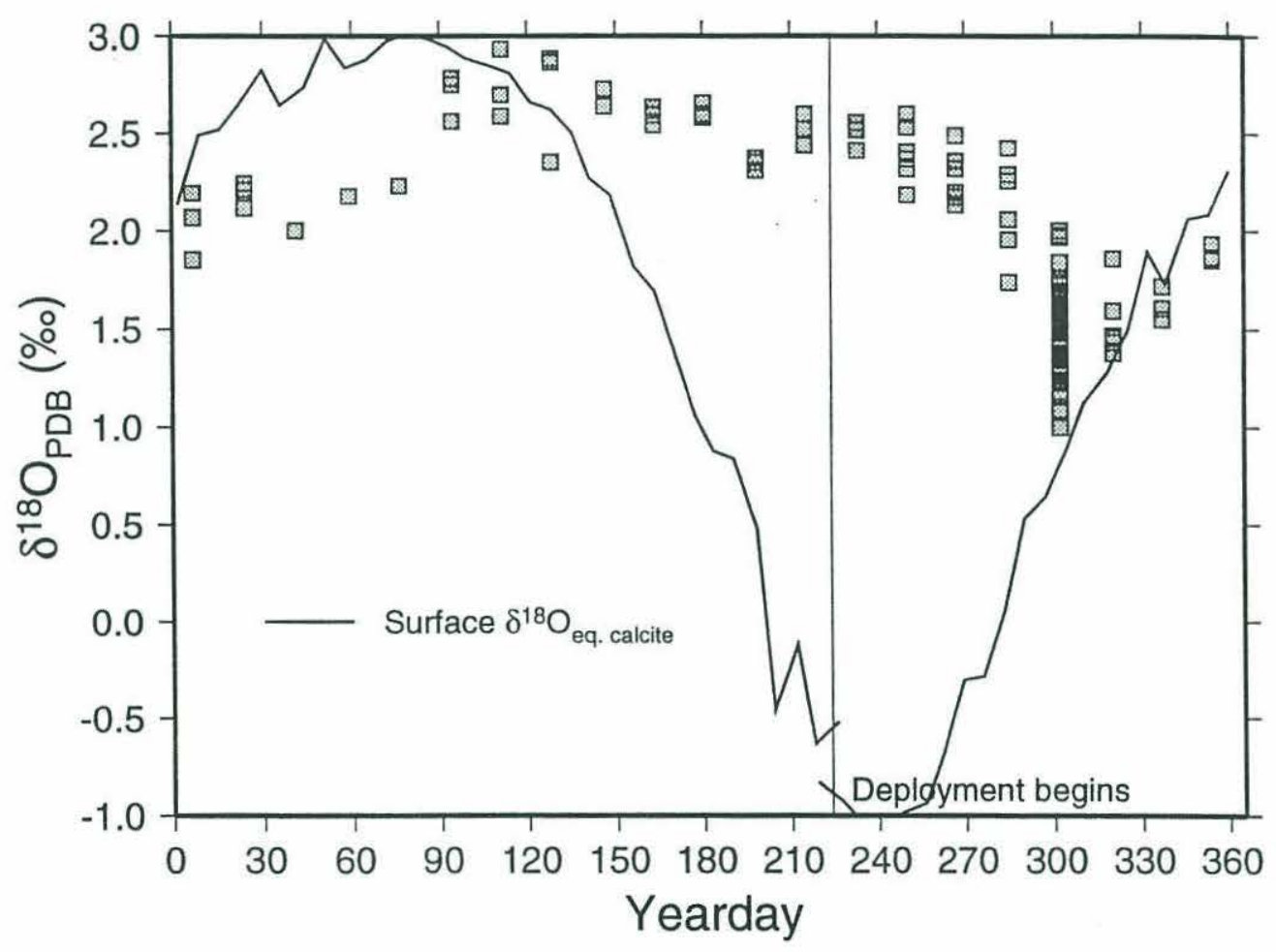

Figure 16 Yearlong $\delta^{18} \mathrm{O}$ time series for $N$. pachyderma (1), 150-250 $\mu \mathrm{m}$ size

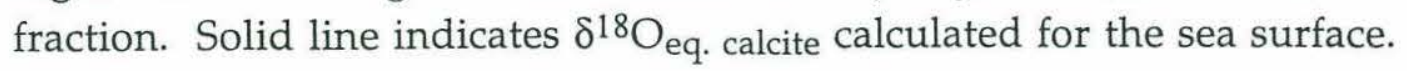




\section{G. bulloides}

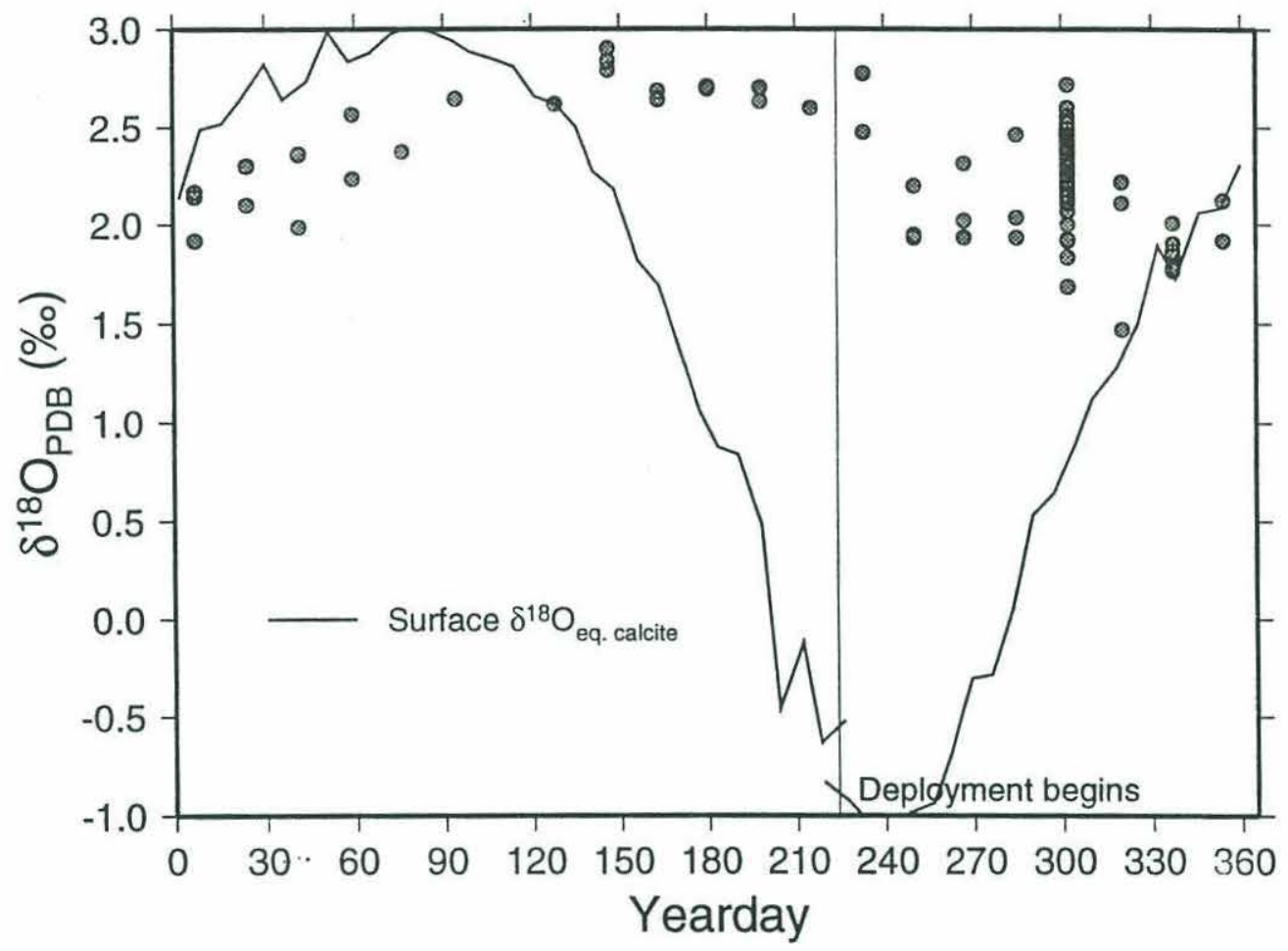

Figure 17 Yearlong $\delta^{18} \mathrm{O}$ time series for G. bulloides, $150-250 \mu \mathrm{m}$ size fraction.

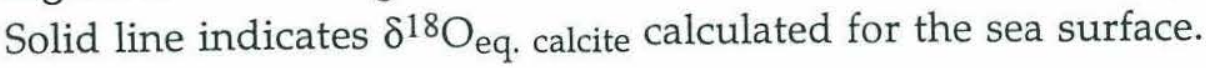


N. pachyderma

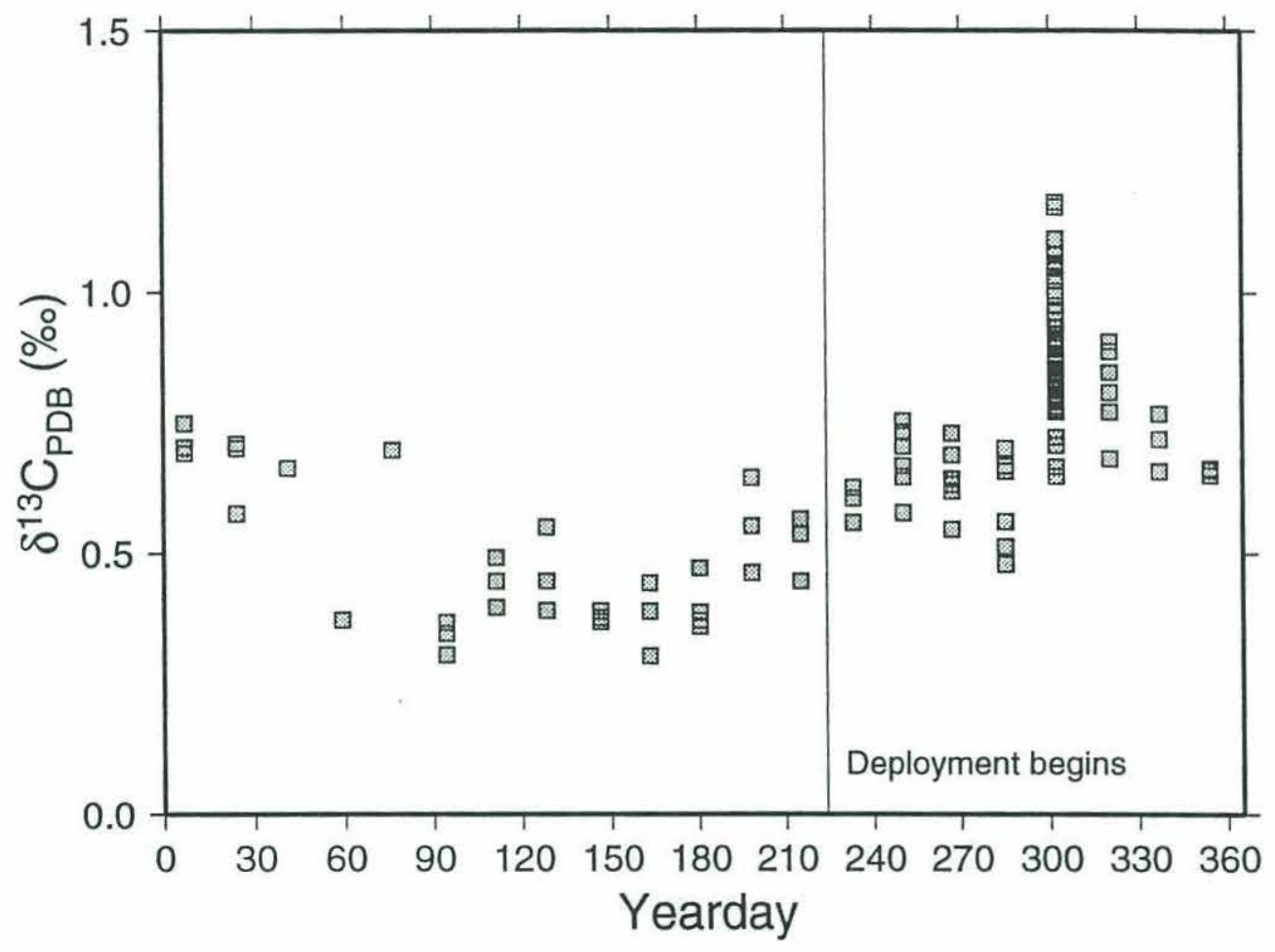

Figure 18 Yearlong $\delta^{13} \mathrm{C}$ time series for $N$. pachyderma (1), 150-250 $\mu \mathrm{m}$ size fraction. 


\section{G. bulloides}

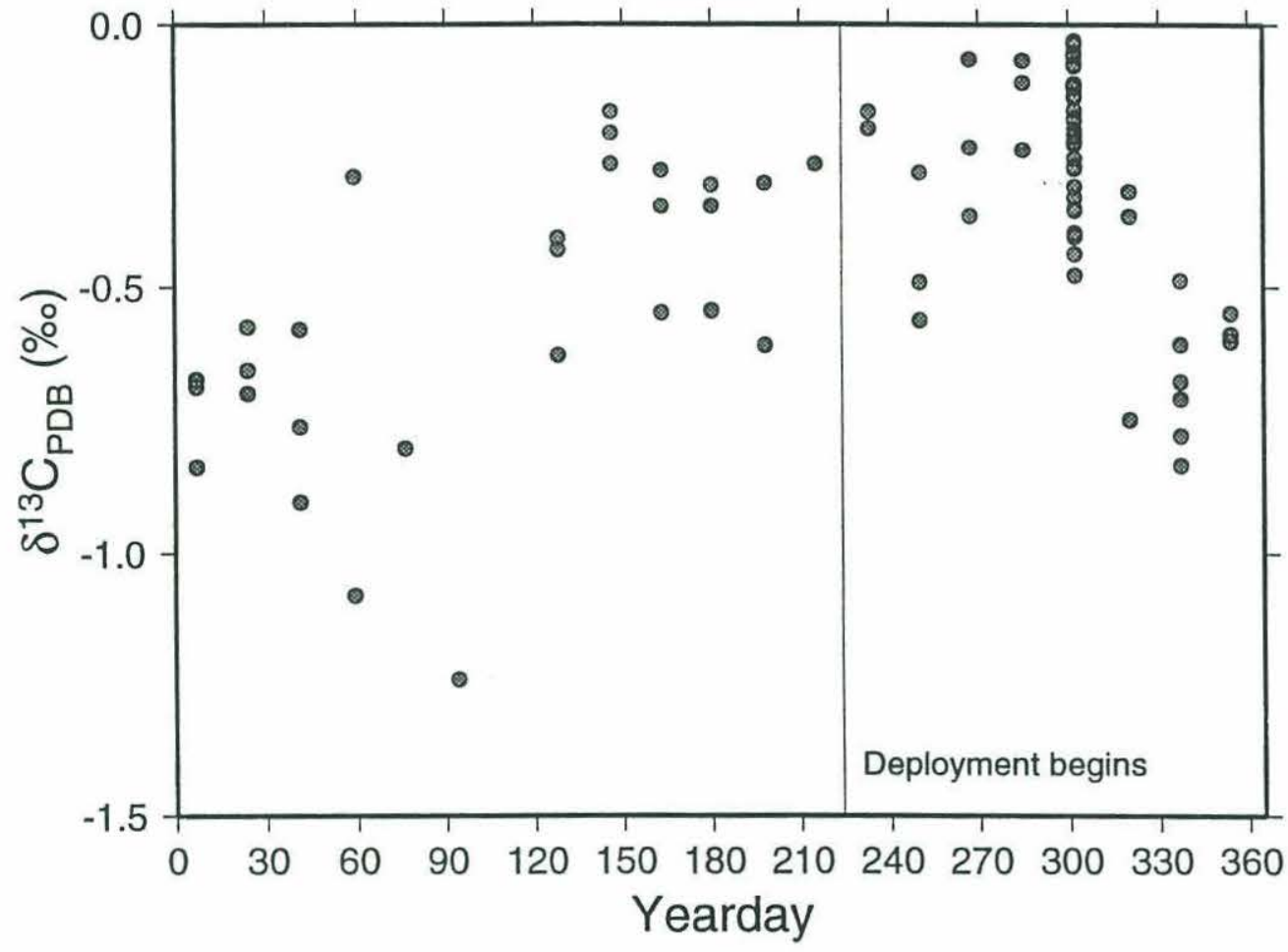

Figure 19 Yearlong $\delta^{13} \mathrm{C}$ time series for G. bulloides, $150-250 \mu \mathrm{m}$ size fraction. 


\section{N. pachyderma}

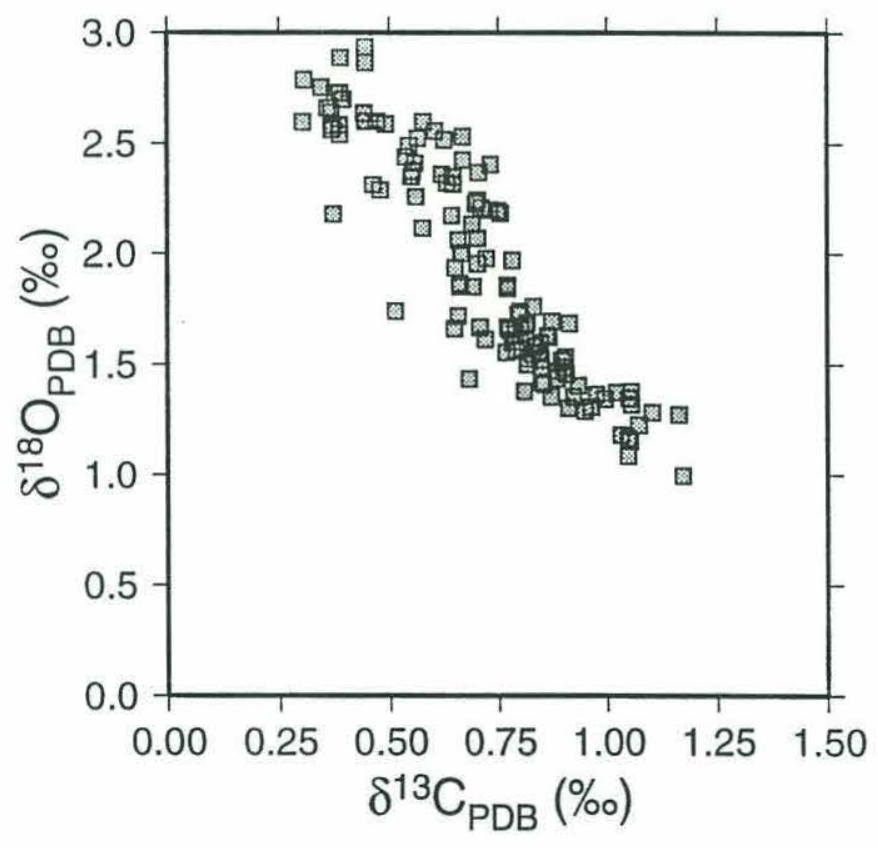

Figure $20 \mathrm{~N}$. pachyderma (1) yearlong time series isotopic data, $\delta^{18} \mathrm{O}$ versus $\delta^{13} \mathrm{C}(150-250 \mu \mathrm{m}$ size fraction). 


\section{G. bulloides}

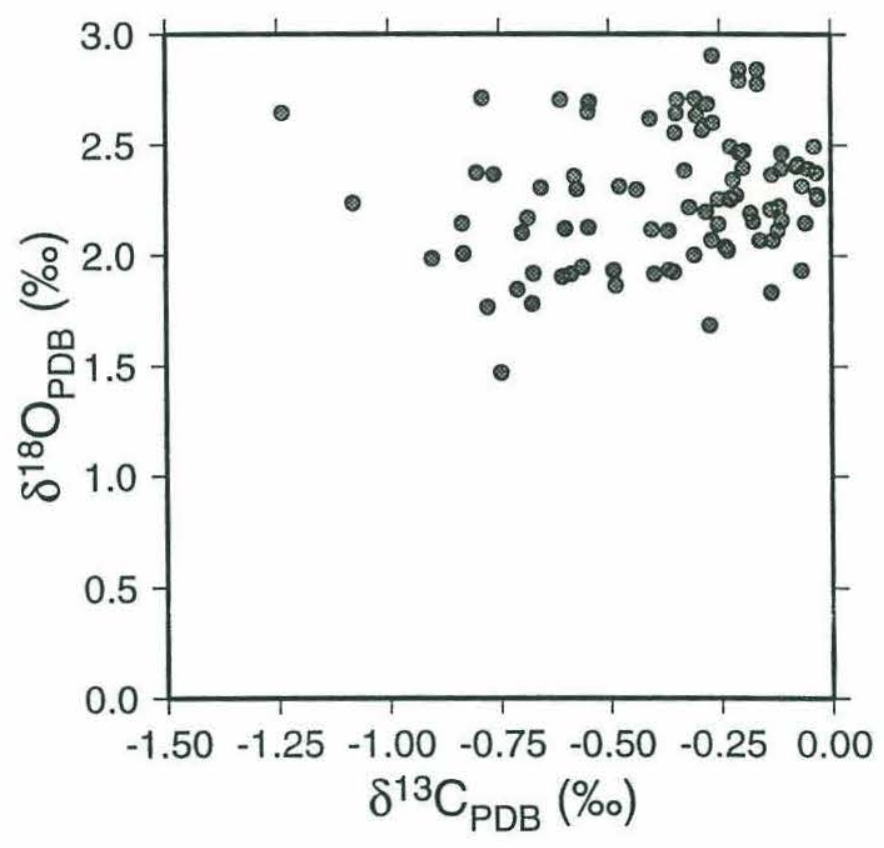

Figure $21 \mathrm{G}$. bulloides yearlong time series isotopic data, $\delta^{18} \mathrm{O}$ versus $\delta^{13} \mathrm{C}$ $(150-250 \mu \mathrm{m}$ size fraction). 


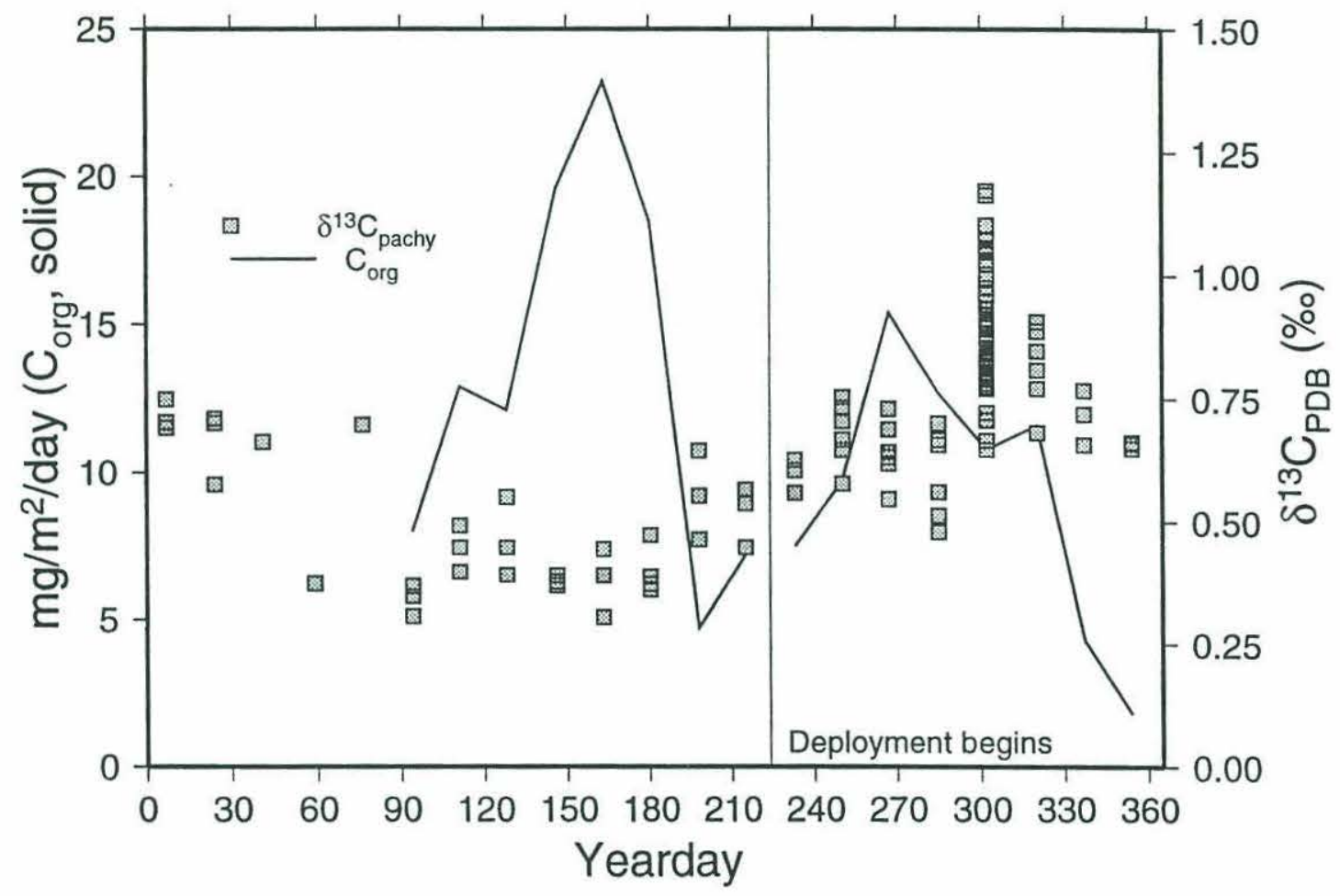

Figure $22 N$. pachyderma (1) $\delta^{13} \mathrm{C}$ yearlong time series (squares, as in Figure 18) and organic carbon flux (solid line, as in Figure 6). 


\section{Equilibrium Calcite}

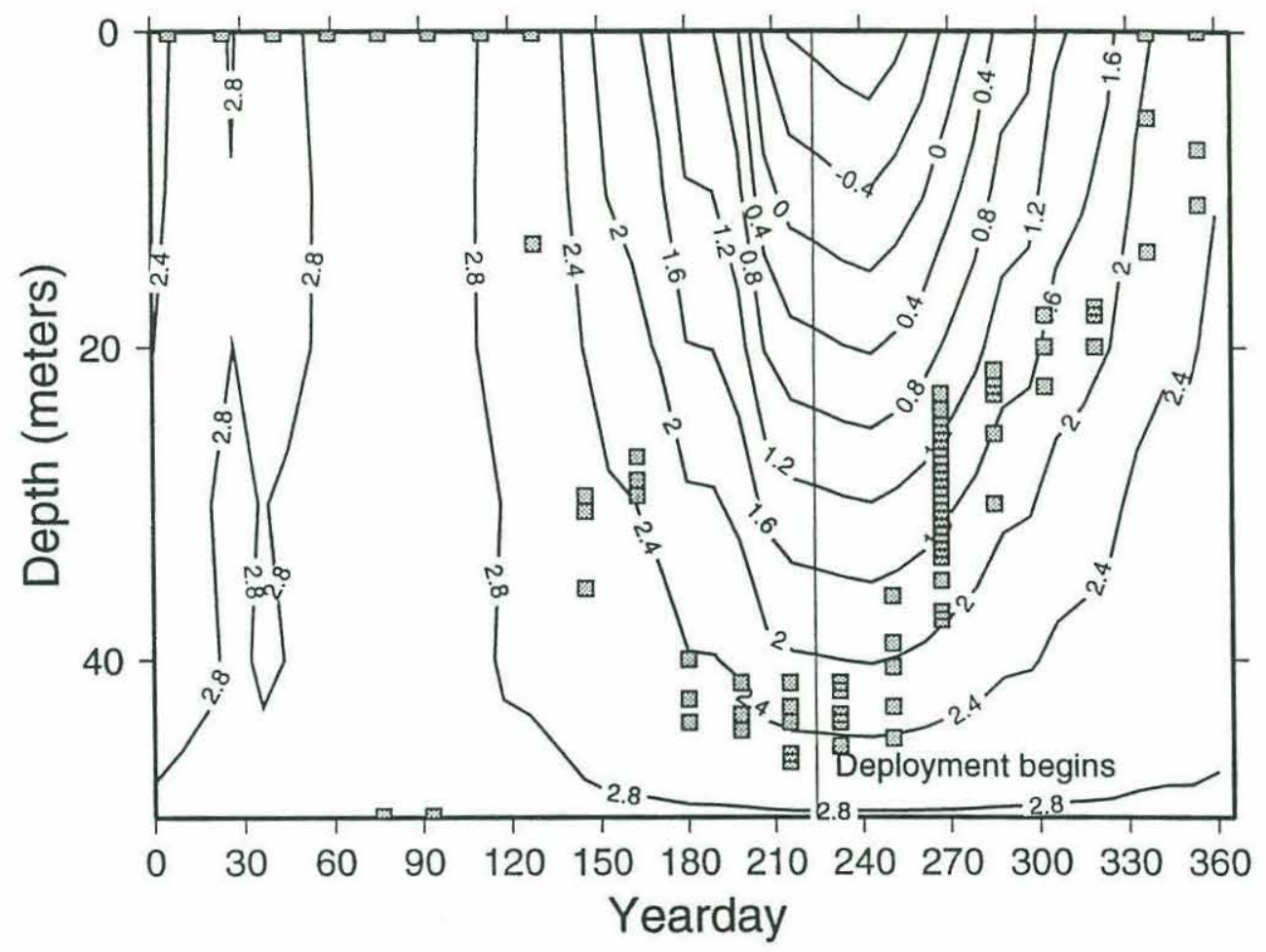

Figure 23 Calcification depths for N. pachyderma (1) (squares) calculated from the $\delta^{18} \mathrm{O}$ of equilibrium calcite. $\delta^{18} \mathrm{O}_{\text {foram }}$ values lighter (heavier) than those seen in the upper 50 meters of the water column are plotted at the surface (50 meters). 


\section{Equilibrium Calcite}

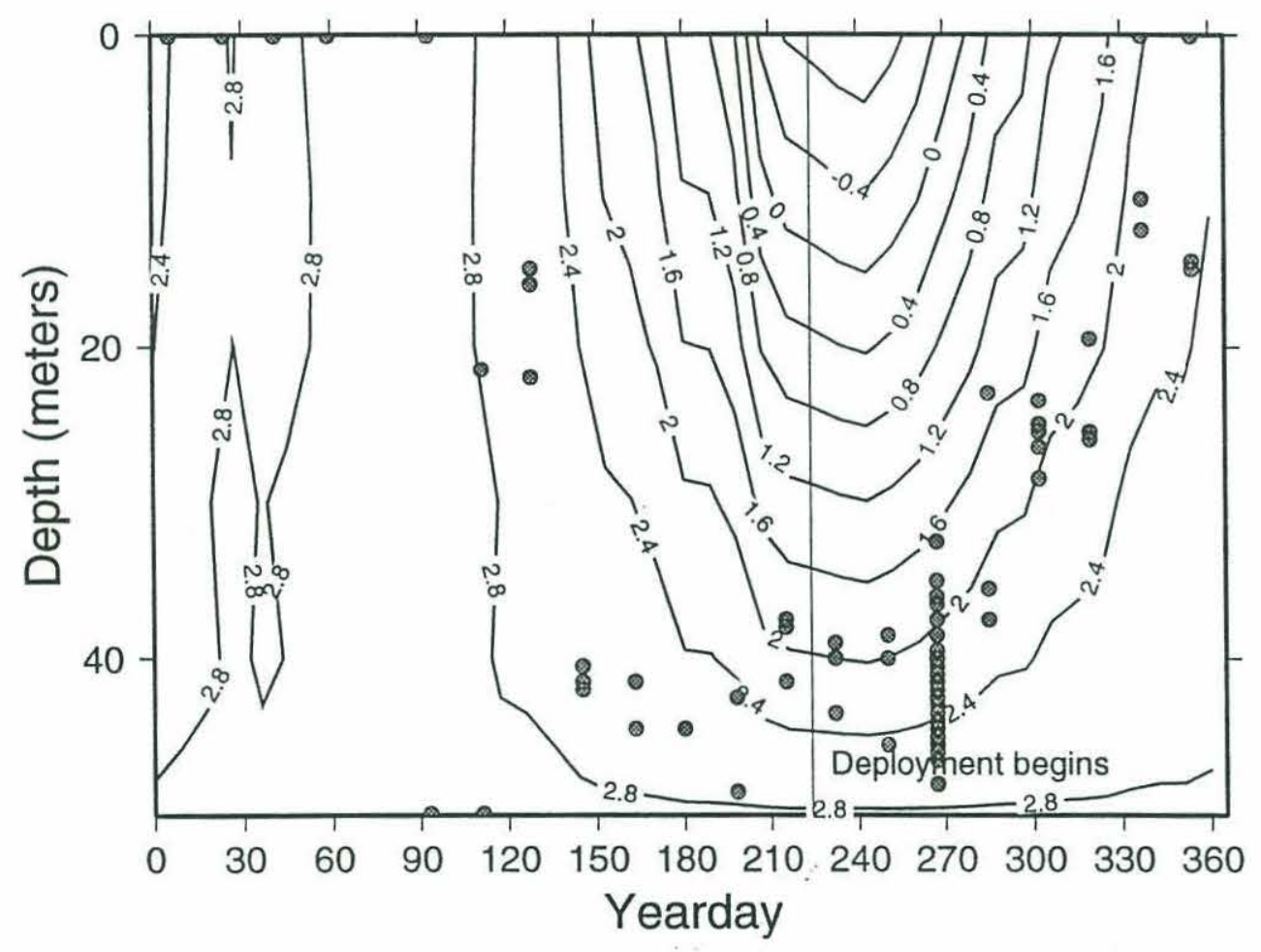

Figure 24 As for Figure 23, but for G. bulloides data. 


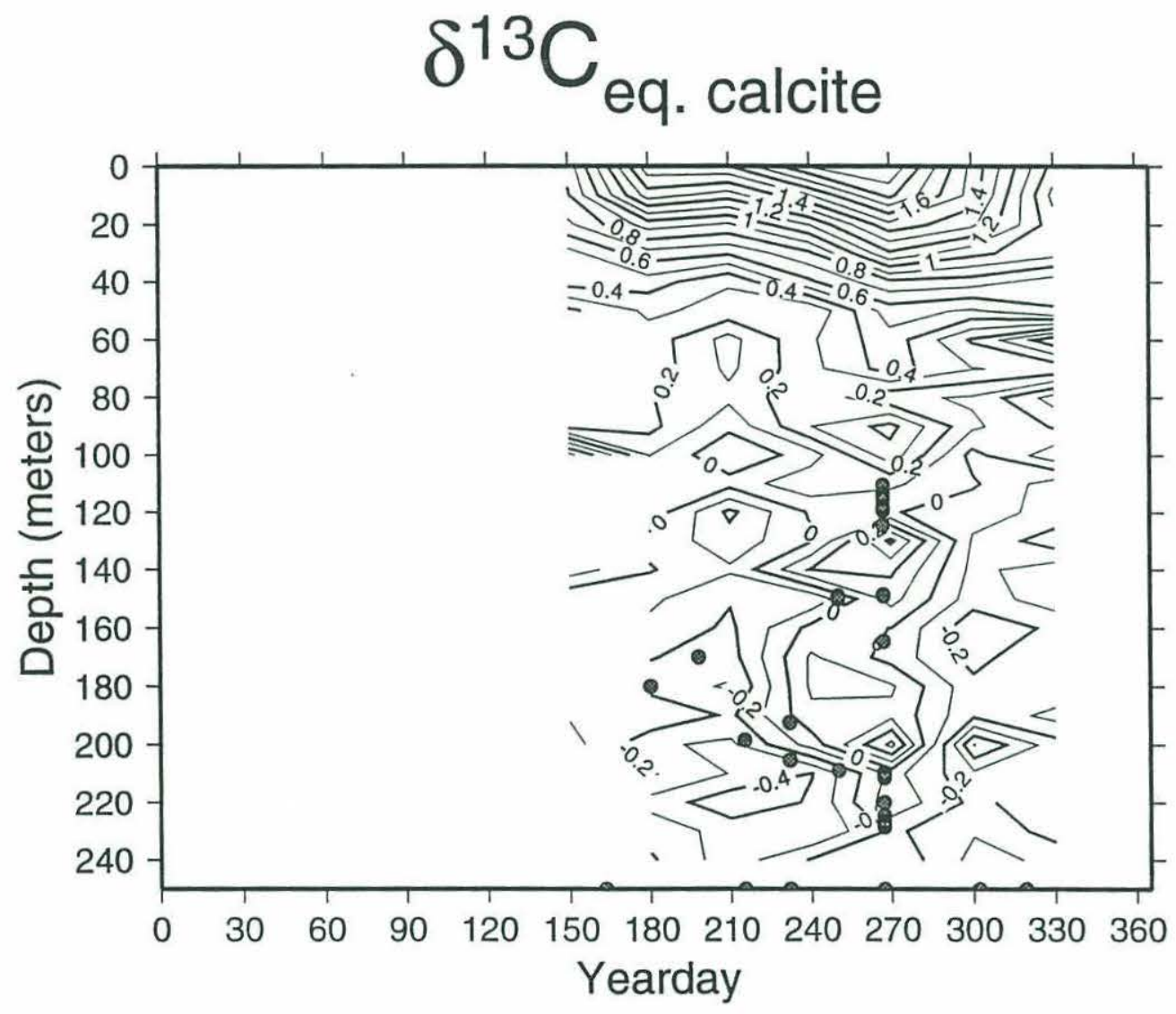

Figure $25 \delta^{13} \mathrm{C}_{\text {eq. }}$ calcite calculated using available phosphate and temperature data (from NODC) for the Sea of Okhotsk. Variability below 100 meters is an artifact of data availability. Calcification depths for G. bulloides are indicated as circles. 


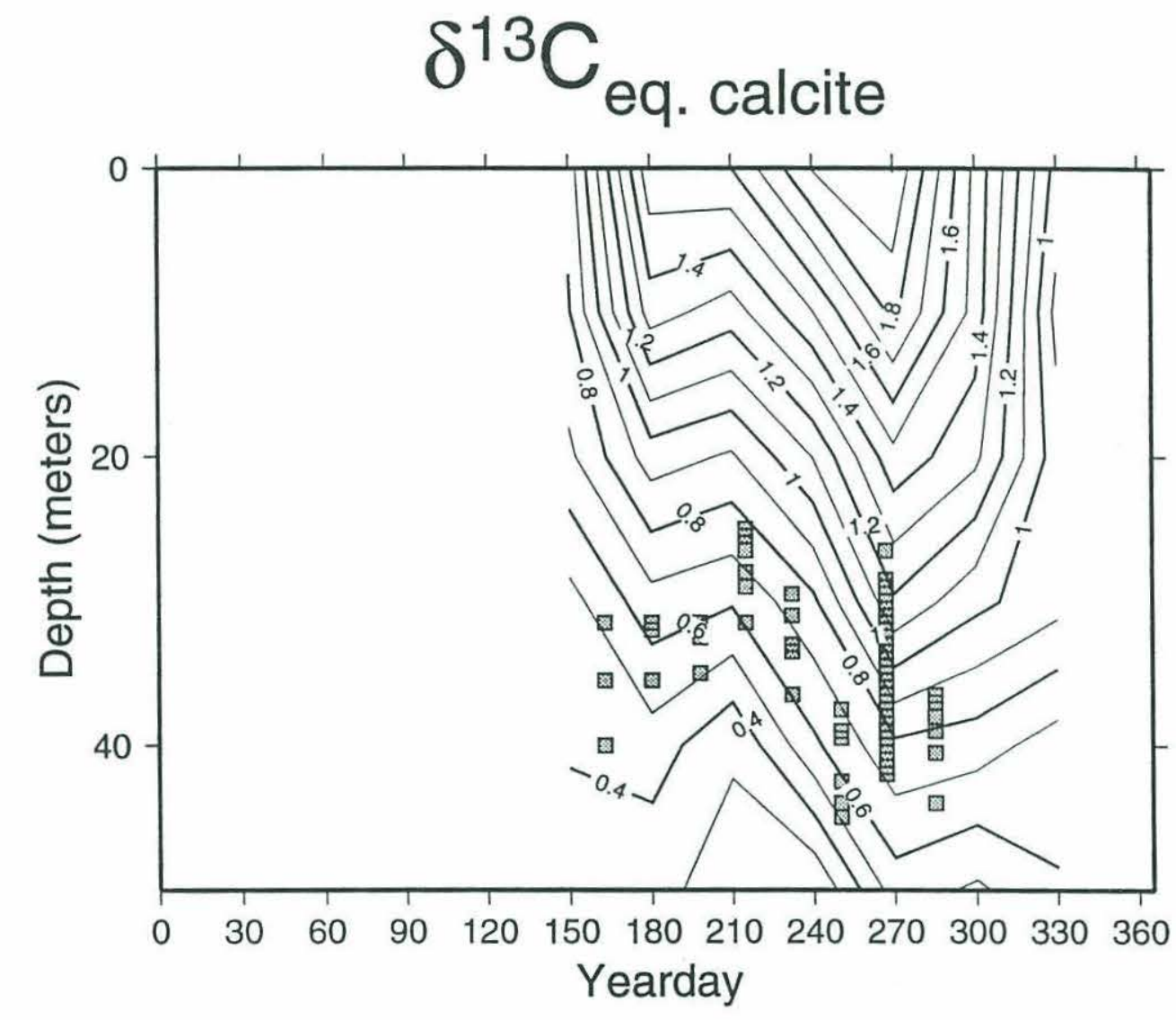

Figure 26 Calcification depths for $N$. pachyderma (l) calculated from the $\delta^{13} \mathrm{C}$ of equilibrium calcite. 


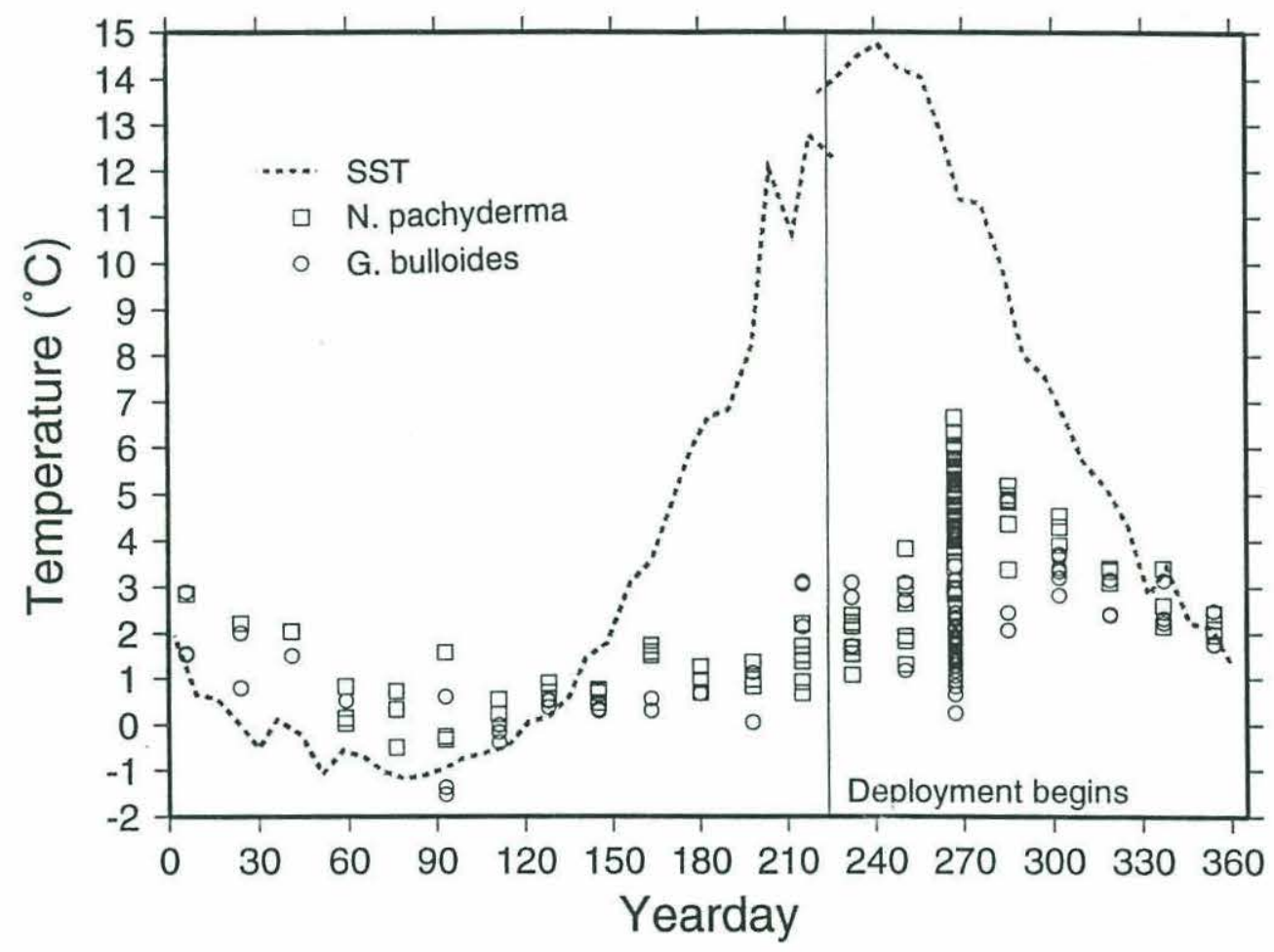

Figure 27 Synoptic SST (dotted) and paleotemperatures calculated from $N$. pachyderma (l) (squares) and G. bulloides $\delta^{18} \mathrm{O}$ data. 
Figure 28 Size-Mass Analysis for N. pachyderma (l)
a) Average maximum axis length versus $\delta^{18} \mathrm{O}$.
b) Average mass versus $\delta^{18} \mathrm{O}$.
c) Average maximum axis length versus $\delta^{13} \mathrm{C}$
d) Average mass versus $\delta^{13} \mathrm{C}$.
e) Average maximum axis length versus average mass.
f) $\delta^{18} \mathrm{O}$ versus $\delta^{13} \mathrm{C}$ for $N$. pachyderma (l), size/mass-isotopic analysis measurements only. 

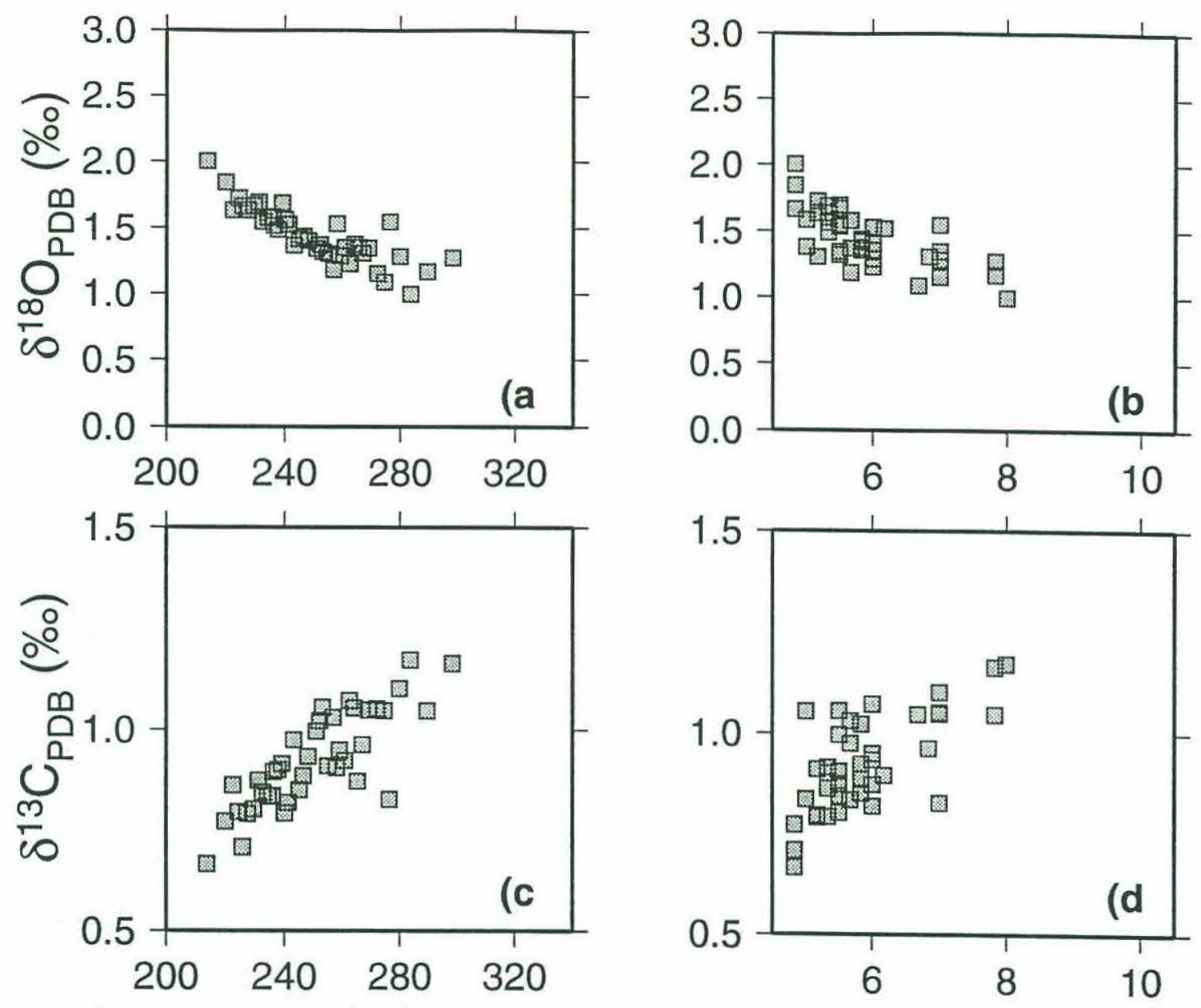

Avg max axis length $(\mu \mathrm{m})$
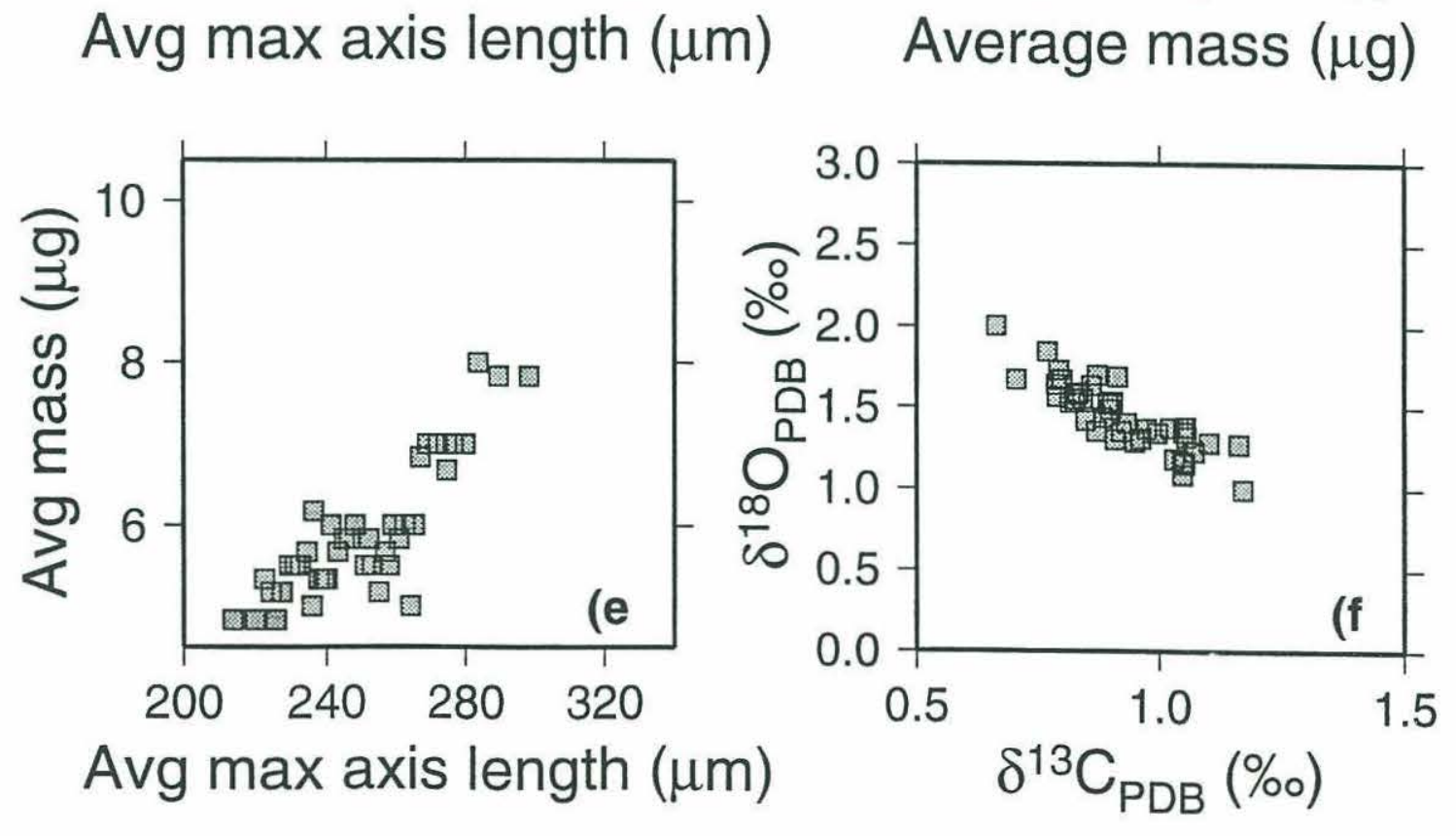
Figure 29 As for Figure 28, for G. bulloides. 

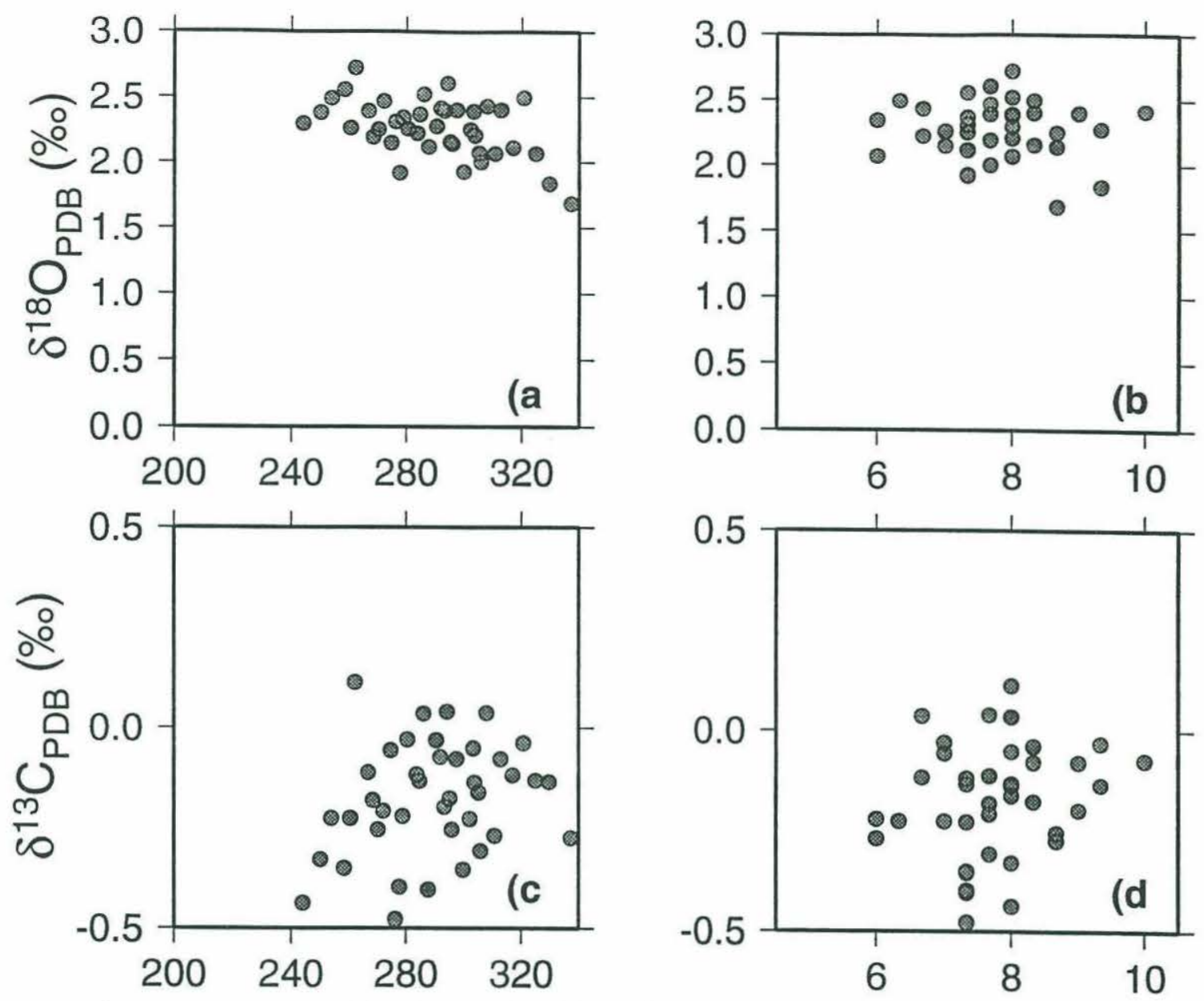

Avg max axis length $(\mu \mathrm{m})$

Average mass $(\mu \mathrm{g})$

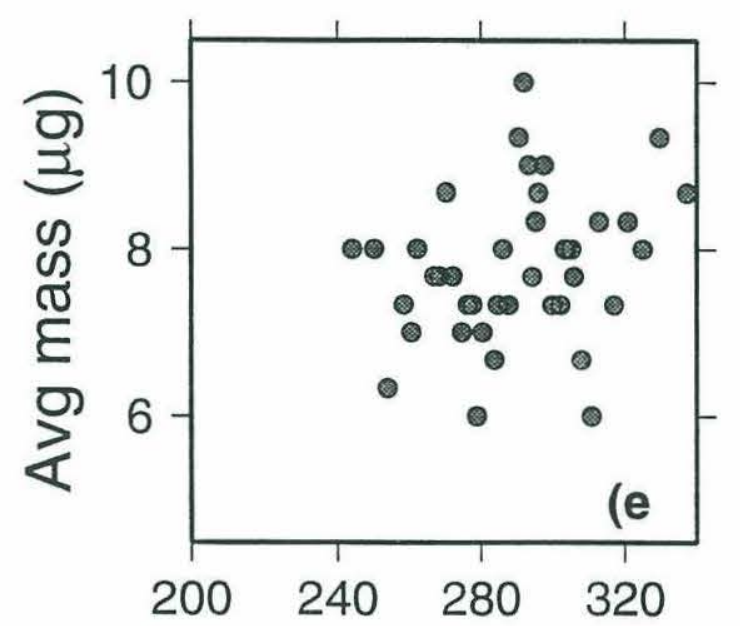

Avg max axis length $(\mu \mathrm{m})$

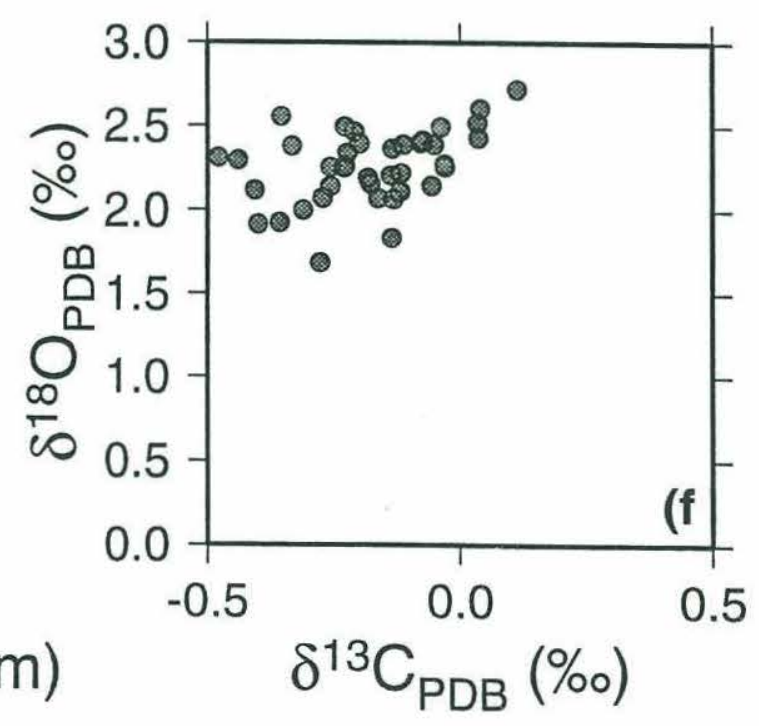




\section{Appendix A}

\begin{tabular}{|c|c|c|c|c|c|c|c|c|c|c|c|}
\hline & & & $\begin{array}{r}\text { Shall } \\
\text { ankton }\end{array}$ & $\begin{array}{l}\text { low } \mathrm{Tr} \\
\text { ic For }\end{array}$ & $\begin{array}{r}\text { Sea o } \\
\text { ap }(25 \\
\text { raminif } \\
150\end{array}$ & $\begin{array}{l}\text { f Okhot } \\
8 \text { meters } \\
\text { eral Flu } \\
-250 \mathrm{um}\end{array}$ & $\begin{array}{l}\text { tsk } \\
\text { s wate } \\
\text { ux (in } \\
\text { n }\end{array}$ & $\begin{array}{l}r \text { depth } \\
\operatorname{div} / \mathrm{m}^{2} /\end{array}$ & day) & & \\
\hline cup\# & Yrday & \begin{tabular}{|c|}
$\mathrm{G}$. \\
bulloides
\end{tabular} & $\begin{array}{c}\mathrm{G} . \\
\text { quin- } \\
\text { queloba }\end{array}$ & \begin{tabular}{|c|} 
N. \\
pachy- \\
L \\
\end{tabular} & \begin{tabular}{|c|} 
N. \\
pachy- \\
R \\
\end{tabular} & \begin{tabular}{|c|} 
G. \\
dutertrei
\end{tabular} & $\begin{array}{c}\text { G. } \\
\text { scitula }\end{array}$ & \begin{tabular}{|c|} 
G. glu- \\
tinata
\end{tabular} & $\begin{array}{c}\text { G. } \\
\text { uvula }\end{array}$ & Other & TOTAL \\
\hline 1 & 233 & 55 & 455 & 910 & 9 & 5 & 0 & 0 & 28 & 0 & 1462 \\
\hline 2 & 250 & 101 & 1490 & 2023 & 32 & 9 & 0 & 5 & 129 & 0 & 3789 \\
\hline 3 & 267 & 1131 & 782 & 4556 & 9 & 106 & 0 & 0 & 106 & 0 & 6690 \\
\hline 4 & 285 & 1623 & 763 & 5021 & 23 & 313 & 0 & 18 & 14 & 5 & 7779 \\
\hline 5 & 302 & 1214 & 1076 & 5867 & 110 & 299 & 0 & 9 & 0 & 9 & 8584 \\
\hline 6 & 320 & 1747 & 699 & 5430 & 78 & 253 & 0 & 18 & 0 & 14 & 8239 \\
\hline 7 & 337 & 846 & 55 & 1145 & 28 & 41 & 0 & 14 & 5 & 9 & 2143 \\
\hline 8 & 354 & 423 & 5 & 543 & 5 & 9 & 0 & 5 & 0 & 0 & 989 \\
\hline 9 & 7 & 474 & 9 & 506 & 5 & 14 & 0 & 5 & 0 & 0 & 1011 \\
\hline 10 & 24 & 221 & 0 & 244 & 5 & 0 & 0 & 14 & 0 & 0 & 483 \\
\hline 11 & 41 & 101 & 0 & 124 & 0 & 5 & 0 & 0 & 0 & 5 & 234 \\
\hline 12 & 59 & 64 & 0 & 64 & 0 & 0 & 0 & 5 & 0 & 0 & 133 \\
\hline 13 & 76 & 23 & 9 & 28 & 0 & 0 & 0 & 0 & 0 & 0 & 60 \\
\hline 14 & 94 & 46 & 0 & 198 & 5 & 5 & 0 & 5 & 0 & 0 & 257 \\
\hline 15 & 111 & 110 & 5 & 428 & 9 & 14 & 0 & 37 & 0 & 0 & 602 \\
\hline 16 & 128 & 101 & 5 & 547 & 5 & 9 & 0 & 9 & 0 & 0 & 676 \\
\hline 17 & 146 & 257 & 37 & 3453 & 23 & 74 & 0 & 32 & 0 & 0 & 3876 \\
\hline 18 & 163 & 202 & 97 & 4874 & 37 & 377 & 0 & 0 & 9 & 5 & 5600 \\
\hline 19 & 180 & 299 & 32 & 2933 & 41 & 248 & 0 & 5 & 0 & 5 & 3563 \\
\hline 20 & 198 & 46 & 9 & 400 & 5 & 23 & 0 & 0 & 0 & 0 & 483 \\
\hline 21 & 215 & 18 & 9 & 391 & $\overline{0}$ & 0 & 5 & 0 & 0 & 0 & 423 \\
\hline
\end{tabular}




\section{Appendix A (continued)}

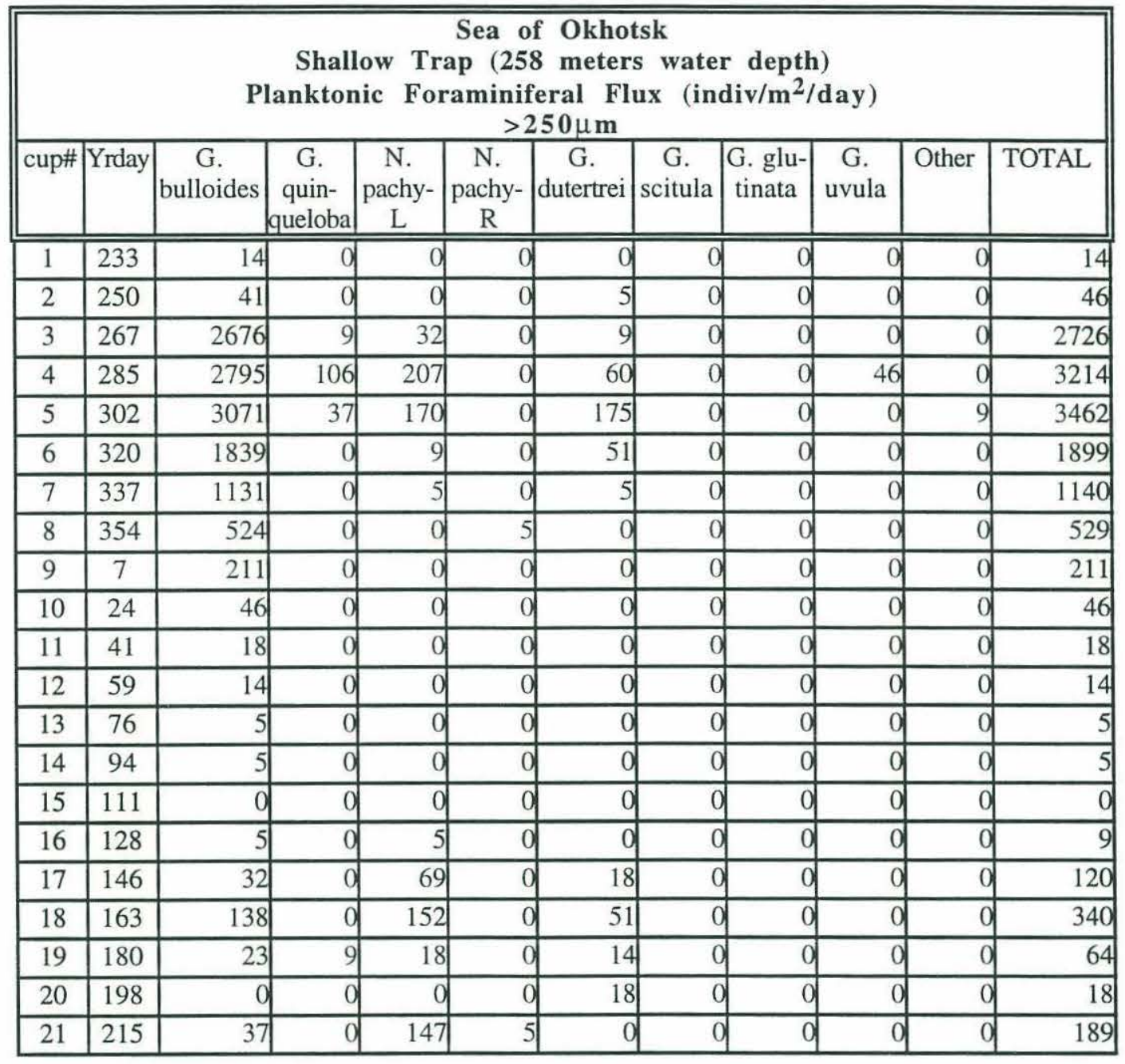




\section{Appendix A (continued)}

\begin{tabular}{|c|c|c|c|c|c|c|c|c|c|c|c|}
\hline & & Plank & nic Fo & oramin & $\begin{array}{l}\text { Sea of } \\
\text { ap }(258 \\
\text { iferal } \\
150 .\end{array}$ & $\begin{array}{l}\text { Okhots } \\
\text { meters } \\
\text { Percenta } \\
-250 \mu \mathrm{m}\end{array}$ & $\begin{array}{l}\text { sk } \\
\text { water } \\
\text { age (\# }\end{array}$ & dep & & \#) & \\
\hline cup\# & Yrday & \begin{tabular}{|c|}
$\mathrm{G}$. \\
bulloides \\
\end{tabular} & \begin{tabular}{|c|} 
G. \\
quin- \\
queloba
\end{tabular} & \begin{tabular}{|c|}
$\mathrm{N}$. \\
pachy- \\
$\mathrm{L}$
\end{tabular} & \begin{tabular}{|c|}
$\mathrm{N}$. \\
pachy- \\
$\mathrm{R}$
\end{tabular} & \begin{tabular}{c|c} 
G. \\
dutertrei
\end{tabular} & \begin{tabular}{c|} 
G. \\
scitula
\end{tabular} & $\begin{array}{l}\text { G. glu- } \\
\text { tinata }\end{array}$ & $\begin{array}{c}\text { G. } \\
\text { uvula }\end{array}$ & Other & TOTAL \\
\hline 1 & 233 & 3.77 & 31.13 & 62.26 & 0.63 & 0.31 & 0.00 & 0.00 & 1.89 & 0.00 & 100.00 \\
\hline 2 & 250 & 2.67 & 39.32 & 53.40 & 0.85 & 0.24 & 0.00 & 0.12 & 3.40 & 0.00 & 100.00 \\
\hline 3 & 267 & 16.91 & 11.68 & 68.11 & 0.14 & 1.58 & 0.00 & 0.00 & 1.58 & 0.00 & 100.00 \\
\hline 4 & 285 & 20.86 & 9.81 & 64.54 & 0.30 & 4.02 & 0.00 & 0.24 & 0.18 & 0.06 & 100.00 \\
\hline 5 & 302 & 14.14 & 12.53 & 68.34 & 1.29 & 3.48 & 0.00 & 0.11 & 0.00 & 0.11 & 100.00 \\
\hline 6 & 320 & 21.21 & 8.48 & 65.90 & 0.95 & 3.07 & 0.00 & 0.22 & 0.00 & 0.17 & 100.00 \\
\hline 7 & 337 & 39.48 & 2.58 & 53.43 & 1.29 & 1.93 & 0.00 & 0.64 & 0.21 & 0.43 & 100.00 \\
\hline 8 & 354 & 42.79 & 0.47 & 54.88 & 0.47 & 0.93 & 0.00 & 0.47 & 0.00 & 0.00 & 100.00 \\
\hline 9 & 7 & 46.82 & 0.91 & 50.00 & 0.45 & 1.36 & 0.00 & 0.45 & 0.00 & 0.00 & 100.00 \\
\hline 10 & 24 & 45.71 & 0.00 & 50.48 & 0.95 & 0.00 & 0.00 & 2.86 & 0.00 & 0.00 & 100.00 \\
\hline 11 & 41 & 43.14 & 0.00 & 52.94 & 0.00 & 1.96 & 0.00 & 0.00 & 0.00 & 1.96 & 100.00 \\
\hline 12 & 59 & 48.28 & 0.00 & 48.28 & 0.00 & 0.00 & 0.00 & 3.45 & 0.00 & 0.00 & 100.00 \\
\hline 13 & 76 & 38.46 & 15.38 & 46.15 & 0.00 & 0.00 & 0.00 & 0.00 & 0.00 & 0.00 & 100.00 \\
\hline 14 & 94 & 17.86 & 0.00 & 76.79 & 1.79 & 1.79 & 0.00 & 1.79 & 0.00 & 0.00 & 100.00 \\
\hline 15 & 111 & 18.32 & 0.76 & 70.99 & 1.53 & 2.29 & 0.00 & 6.11 & 0.00 & 0.00 & 100.00 \\
\hline 16 & 128 & 14.97 & 0.68 & 80.95 & 0.68 & 1.36 & 0.00 & 1.36 & 0.00 & 0.00 & 100.00 \\
\hline 17 & 146 & 6.64 & 0.95 & 89.09 & 0.59 & 1.90 & 0.00 & 0.83 & 0.00 & 0.00 & 100.00 \\
\hline 18 & 163 & 3.61 & 1.72 & 87.03 & 0.66 & 6.73 & 0.00 & 0.00 & 0.16 & 0.08 & 100.00 \\
\hline 19 & 180 & 8.39 & 0.90 & 82.32 & 1.16 & 6.97 & 0.00 & 0.13 & 0.00 & 0.13 & 100.00 \\
\hline 20 & 198 & 9.52 & 1.90 & 82.86 & 0.95 & 4.76 & 0.00 & 0.00 & 0.00 & 0.00 & 100.00 \\
\hline 21 & 215 & 4.35 & 2.17 & 92.39 & 0.00 & 0.00 & 1.09 & 0.00 & 0.00 & 0.00 & 100.00 \\
\hline
\end{tabular}




\section{Appendix A (continued)}

\begin{tabular}{|c|c|c|c|c|c|c|c|c|c|c|c|}
\hline & & Plankt & $\begin{array}{l}\text { Shallo } \\
\text { onic Fo }\end{array}$ & $\begin{array}{l}\text { ow Tra } \\
\text { oramini }\end{array}$ & $\begin{array}{l}\text { Sea of } \\
\text { p }(258 \\
\text { iferal } P \\
\qquad>25\end{array}$ & $\begin{array}{l}\text { Okhots } \\
\text { meters } \\
\text { Percenta } \\
50 \mu \mathrm{m}\end{array}$ & $\begin{array}{l}\text { sk } \\
\text { s water } \\
\text { age }(\#\end{array}$ & spe & total & \#) & \\
\hline cup\# & Yrday & \begin{tabular}{|c|c|} 
G. & \\
bulloides & \\
& qu \\
\end{tabular} & \begin{tabular}{|c|} 
G. \\
quin- \\
queloba
\end{tabular} & \begin{tabular}{c|c}
$\mathrm{N}$. \\
pachy- \\
L
\end{tabular} & \begin{tabular}{c|c} 
N. \\
pachy- \\
R
\end{tabular} & \begin{tabular}{c|c} 
G. \\
dutertrei
\end{tabular} & \begin{tabular}{c|c} 
G. \\
scitula
\end{tabular} & \begin{tabular}{|c|} 
G. glu- \\
tinata
\end{tabular} & $\begin{array}{c}\text { G. } \\
\text { uvula }\end{array}$ & Other & TOTAL \\
\hline 1 & 233 & 100.00 & 0.00 & 0.00 & 0.00 & 0.00 & 0.00 & 0.00 & 0.00 & 0.00 & 100.00 \\
\hline 2 & 250 & 90.00 & 0.00 & 0.00 & 0.00 & 10.00 & 0.00 & 0.00 & 0.00 & 0.00 & 100.00 \\
\hline 3 & 267 & 98.15 & 0.34 & 1.18 & 0.00 & 0.34 & 0.00 & 0.00 & 0.00 & 0.00 & 100.00 \\
\hline 4 & 285 & 86.98 & 3.29 & 6.44 & 0.00 & 1.86 & 0.00 & 0.00 & 1.43 & 0.00 & 100.00 \\
\hline 5 & 302 & 88.71 & 1.06 & 4.91 & 0.00 & 5.05 & 0.00 & 0.00 & 0.00 & 0.27 & 100.00 \\
\hline 6 & 320 & 96.85 & 0.00 & 0.48 & 0.00 & 2.66 & 0.00 & 0.00 & 0.00 & 0.00 & 100.00 \\
\hline 7 & 337 & 99.19 & 0.00 & 0.40 & 0.00 & 0.40 & 0.00 & 0.00 & 0.00 & 0.00 & 100.00 \\
\hline 8 & 354 & 99.13 & 0.00 & 0.00 & 0.87 & 0.00 & 0.00 & 0.00 & 0.00 & 0.00 & 100.00 \\
\hline 9 & 7 & 100.00 & 0.00 & 0.00 & 0.00 & 0.00 & 0.00 & 0.00 & 0.00 & 0.00 & 100.00 \\
\hline 10 & 24 & 100.00 & 0.00 & 0.00 & 0.00 & 0.00 & 0.00 & 0.00 & 0.00 & 0.00 & 100.00 \\
\hline 11 & 41 & 100.00 & 0.00 & 0.00 & 0.00 & 0.00 & 0.00 & 0.00 & 0.00 & 0.00 & 100.00 \\
\hline 12 & 59 & 100.00 & 0.00 & 0.00 & 0.00 & 0.00 & 0.00 & 0.00 & 0.00 & 0.00 & 100.00 \\
\hline 13 & 76 & 100.00 & 0.00 & 0.00 & 0.00 & 0.00 & 0.00 & 0.00 & 0.00 & 0.00 & 100.00 \\
\hline 14 & 94 & 100.00 & 0.00 & 0.00 & 0.00 & 0.00 & 0.00 & 0.00 & 0.00 & 0.00 & 100.00 \\
\hline 15 & 111 & 0.00 & 0.00 & 0.00 & 0.00 & 0.00 & 0.00 & 0.00 & 0.00 & 0.00 & 100.00 \\
\hline 16 & 128 & 50.00 & 0.00 & 50.00 & 0.00 & 0.00 & 0.00 & 0.00 & 0.00 & 0.00 & 100.00 \\
\hline 17 & 146 & 26.92 & 0.00 & 57.69 & 0.00 & 15.38 & 0.00 & 0.00 & 0.00 & 0.00 & 100.00 \\
\hline 18 & 163 & 40.54 & 0.00 & 44.59 & 0.00 & 14.86 & 0.00 & 0.00 & 0.00 & 0.00 & 100.00 \\
\hline 19 & 180 & 35.71 & 14.29 & 28.57 & 0.00 & 21.43 & 0.00 & 0.00 & 0.00 & 0.00 & 100.00 \\
\hline 20 & 198 & 0.00 & 0.00 & 0.00 & 0.00 & 100.00 & 0.00 & 0.00 & 0.00 & 0.00 & 100.00 \\
\hline 21 & 215 & 19.51 & 0.00 & 78.05 & 2.44 & 0.00 & 0.00 & 0.00 & 0.00 & 0.00 & 100.00 \\
\hline
\end{tabular}


Appendix B

\begin{tabular}{|c|c|c|c|c|c|c|c|}
\hline Cup\# & $\begin{array}{l}\text { Year- } \\
\text { day }\end{array}$ & Species & Line & Vial & $\begin{array}{c}\text { Single } \\
\text { Shell } \\
\text { Mass } \\
(\mu \mathrm{g}) \\
\end{array}$ & $\begin{array}{c}\delta^{13} \mathrm{C} \\
\left(\%{ }^{\circ} \text { PD B }\right)\end{array}$ & $\begin{array}{c}\delta^{18} \mathrm{O} \\
(\% \text { PDB })\end{array}$ \\
\hline cup1 & 233 & G.bulloides & A & 16 & 5.67 & -0.165 & 2.775 \\
\hline cup1 & 233 & G.bulloides & B & 15 & 5.33 & -0.197 & 2.473 \\
\hline cup1 & 233 & N.pachy-L & $\mathrm{A}$ & 3 & 2.83 & 0.558 & 2.410 \\
\hline cup1 & 233 & N.pachy-L & $\mathrm{A}$ & 4 & 4.50 & 0.604 & 2.555 \\
\hline cup1 & 233 & N.pachy-L & $B$ & 3 & 2.00 & 0.625 & 2.516 \\
\hline cup2 & 250 & G.bulloides & $\mathrm{A}$ & 3 & 5.00 & -0.491 & 1.931 \\
\hline cup2 & 250 & G.bulloides & $\mathrm{A}$ & 4 & 8.33 & -0.562 & 1.945 \\
\hline cup2 & 250 & G.bulloides & $B$ & 3 & 7.00 & -0.282 & 2.195 \\
\hline cup2 & 250 & N.pachy-L & $\mathrm{A}$ & 17 & 2.33 & 0.667 & 2.532 \\
\hline cup2 & 250 & N.pachy-L & $\mathrm{A}$ & 5 & 3.17 & 0.645 & 2.313 \\
\hline cup2 & 250 & N.pachy-L & $B$ & 16 & 4.67 & 0.576 & 2.598 \\
\hline cup2 & 250 & N.pachy-L & $B$ & 17 & 1.50 & 0.704 & 2.368 \\
\hline cup2 & 250 & N.pachy-L & $\mathrm{B}$ & 4 & 2.00 & 0.753 & 2.180 \\
\hline cup2 & 250 & N.pachy-L & $B$ & 5 & 6.00 & 0.730 & 2.405 \\
\hline cup3 & 267 & G.bulloides & $\mathrm{A}$ & 11 & 9.00 & -0.365 & 1.932 \\
\hline cup3 & 267 & G.bulloides & $\mathrm{A}$ & 12 & 9.33 & -0.065 & 2.312 \\
\hline cup3 & 267 & G.bulloides & $B$ & 11 & 7.00 & -0.234 & 2.021 \\
\hline cup3 & 267 & N.pachy-L & $\mathrm{A}$ & 18 & 1.83 & 0.642 & 2.170 \\
\hline cup3 & 267 & N.pachy-L & $\mathrm{A}$ & 19 & 3.83 & 0.631 & 2.319 \\
\hline cup3 & 267 & N.pachy-L & $\mathrm{A}$ & 6 & 4.50 & 0.545 & 2.488 \\
\hline cup3 & 267 & N.pachy-L & $\mathrm{A}$ & 7 & 5.17 & 0.688 & 2.131 \\
\hline cup3 & 267 & N.pachy-L & $\mathrm{B}$ & 18 & 2.33 & 0.729 & 2.194 \\
\hline cup3 & 267 & N.pachy-L & $\mathrm{B}$ & 6 & 4.00 & 0.618 & 2.359 \\
\hline cup4 & 285 & G.bulloides & $\mathrm{A}$ & 14 & 10.00 & -0.067 & 1.932 \\
\hline cup4 & 285 & G.bulloides & $\mathrm{B}$ & 12 & 10.33 & -0.110 & 2.462 \\
\hline cup4 & 285 & G.bulloides & $\mathrm{B}$ & 14 & 6.33 & -0.239 & 2.036 \\
\hline cup4 & 285 & N.pachy-L & $\mathrm{A}$ & 20 & 5.33 & 0.667 & 2.424 \\
\hline cup4 & 285 & N.pachy-L & $\mathrm{A}$ & 8 & 2.50 & 0.560 & 2.255 \\
\hline cup4 & 285 & N.pachy-L & $B$ & 19 & 5.67 & 0.656 & 2.058 \\
\hline cup4 & 285 & N.pachy-L & $B$ & 20 & 6.83 & 0.513 & 1.737 \\
\hline cup4 & 285 & N.pachy-L & $\mathrm{B}$ & 7 & 4.50 & 0.700 & 1.953 \\
\hline cup4 & 285 & N.pachy-L & $\mathrm{B}$ & 8 & 3.33 & 0.479 & 2.286 \\
\hline cup5 & 302 & G.bulloides & $\mathrm{A}$ & 10 & 9.00 & -0.078 & 2.399 \\
\hline cup5 & 302 & G.bulloides & $\mathrm{A}$ & 11 & 8.33 & -0.176 & 2.153 \\
\hline cup5 & 302 & G.bulloides & $\mathrm{A}$ & 12 & 9.00 & -0.199 & 2.393 \\
\hline cup5 & 302 & G.bulloides & $\mathrm{A}$ & 14 & 9.33 & -0.032 & 2.274 \\
\hline cup5 & 302 & G.bulloides & $\mathrm{A}$ & 15 & 11.33 & -0.033 & 2.374 \\
\hline cup5 & 302 & G.bulloides & $\mathrm{A}$ & 15 & \begin{tabular}{|l|}
8.00 \\
\end{tabular} & 0.035 & 2.521 \\
\hline
\end{tabular}




\begin{tabular}{|c|c|c|c|c|c|c|c|}
\hline cup5 & 302 & G.bulloides & $\mathrm{A}$ & 16 & 11.00 & -0.111 & 2.158 \\
\hline cup5 & 302 & G.bulloides & $\mathrm{A}$ & 16 & 6.67 & -0.116 & 2.221 \\
\hline cup5 & 302 & G.bulloides & $\mathrm{A}$ & 17 & 6.00 & -0.221 & 2.339 \\
\hline cup5 & 302 & G.bulloides & $\mathrm{A}$ & 18 & 7.33 & -0.478 & 2.308 \\
\hline cup5 & 302 & G.bulloides & $\mathrm{A}$ & 19 & 7.67 & -0.208 & 2.463 \\
\hline cup5 & 302 & G.bulloides & $\mathrm{A}$ & 20 & 7.67 & -0.182 & 2.188 \\
\hline cup5 & 302 & G.bulloides & $\mathrm{A}$ & 21 & 8.00 & 0.113 & 2.721 \\
\hline cup5 & 302 & G.bulloides & $\mathrm{A}$ & 22 & 7.33 & -0.351 & 2.556 \\
\hline cup5 & 302 & G.bulloides & $\mathrm{A}$ & 23 & 8.00 & -0.330 & 2.381 \\
\hline cup5 & 302 & G.bulloides & $\mathrm{A}$ & 3 & 8.67 & -0.275 & 1.686 \\
\hline cup5 & 302 & G.bulloides & $\mathrm{A}$ & 4 & 8.00 & -0.132 & 2.066 \\
\hline cup5 & 302 & G.bulloides & $\mathrm{A}$ & 5 & 7.33 & -0.119 & 2.111 \\
\hline cup5 & 302 & G.bulloides & $\mathrm{A}$ & 6 & 6.00 & -0.270 & 2.067 \\
\hline cup5 & 302 & G.bulloides & $\mathrm{A}$ & 7 & 7.67 & -0.309 & 2.000 \\
\hline cup5 & 302 & G.bulloides & $\bar{A}$ & 8 & 8.00 & -0.137 & 2.205 \\
\hline cup5 & 302 & G.bulloides & $\mathrm{A}$ & 9 & 7.33 & -0.228 & 2.249 \\
\hline cup5 & 302 & G.bulloides & B & 10 & 8.67 & -0.255 & 2.139 \\
\hline cup5 & 302 & G.bulloides & B & 11 & 7.67 & 0.040 & 2.604 \\
\hline cup5 & 302 & G.bulloides & B & 12 & 10.00 & -0.074 & 2.413 \\
\hline cup5 & 302 & G.bulloides & $B$ & 14 & 7.33 & -0.405 & 2.116 \\
\hline cup5 & 302 & G.bulloides & B & 15 & 10.33 & -0.134 & 2.364 \\
\hline cup5 & 302 & G.bulloides & B & 15 & 10.67 & -0.214 & 2.270 \\
\hline cup5 & 302 & G.bulloides & B & 16 & 7.00 & -0.030 & 2.256 \\
\hline cup5 & 302 & G.bulloides & $B$ & 17 & 7.33 & -0.398 & 1.915 \\
\hline cup5 & 302 & G.bulloides & B & 18 & 7.00 & -0.057 & 2.144 \\
\hline cup5 & 302 & G.bulloides & $B$ & 19 & 8.67 & -0.255 & 2.252 \\
\hline cup5 & 302 & G.bulloides & B & 20 & 7.67 & -0.112 & 2.390 \\
\hline cup5 & 302 & G.bulloides & $B$ & 21 & 7.00 & -0.226 & 2.261 \\
\hline cup5 & 302 & G.bulloides & B & 22 & 6.33 & -0.227 & 2.492 \\
\hline cup5 & 302 & G.bulloides & $B$ & 23 & 8.00 & -0.438 & 2.295 \\
\hline cup5 & 302 & G.bulloides & B & 3 & 9.33 & -0.135 & 1.834 \\
\hline cup5 & 302 & G.bulloides & $B$ & 4 & 8.33 & -0.038 & 2.493 \\
\hline cup5 & 302 & G.bulloides & B & 5 & 8.33 & -0.078 & 2.399 \\
\hline cup5 & 302 & G.bulloides & B & 6 & 6.67 & 0.037 & 2.430 \\
\hline cup5 & 302 & G.bulloides & B & 7 & 8.00 & -0.161 & 2.068 \\
\hline cup5 & 302 & G.bulloides & B & 8 & 8.00 & -0.052 & 2.391 \\
\hline cup5 & 302 & G.bulloides & B & 9 & 10.33 & -0.355 & 1.923 \\
\hline cup5 & 302 & N.pachy-L & $\mathrm{A}$ & 10 & 4.00 & 0.846 & 1.488 \\
\hline cup5 & 302 & N.pachy-L & $\mathrm{A}$ & 10 & 5.50 & 0.904 & 1.530 \\
\hline cup5 & 302 & N.pachy-L & $\mathrm{A}$ & 11 & 5.17 & 0.909 & 1.301 \\
\hline cup5 & 302 & N.pachy-L & $\mathrm{A}$ & 12 & 5.83 & 1.022 & 1.373 \\
\hline cup5 & 302 & N.pachy-L & $\mathrm{A}$ & 14 & 6.00 & 0.932 & 1.403 \\
\hline cup5 & 302 & N.pachy-L & $\mathrm{A}$ & 15 & 5.83 & 0.848 & 1.417 \\
\hline
\end{tabular}




\begin{tabular}{|c|c|c|c|c|c|c|c|}
\hline cup5 & 302 & N.pachy-L & $\mathrm{A}$ & 16 & 6.00 & 0.817 & 1.525 \\
\hline cup5 & 302 & N.pachy-L & $\mathrm{A}$ & 17 & 5.33 & 0.913 & 1.684 \\
\hline cup5 & 302 & N.pachy-L & $\bar{A}$ & 18 & 6.17 & 0.894 & 1.517 \\
\hline cup5 & 302 & N.pachy-L & $\mathrm{A}$ & 19 & 5.67 & 0.832 & 1.577 \\
\hline cup5 & 302 & N.pachy-L & $\mathrm{A}$ & 20 & 5.50 & 0.872 & 1.693 \\
\hline cup5 & 302 & N.pachy-L & $\mathrm{A}$ & 21 & 5.17 & 0.789 & 1.633 \\
\hline cup5 & 302 & N.pachy-L & $\mathrm{A}$ & 21 & 6.50 & 0.770 & 1.665 \\
\hline cup5 & 302 & N.pachy-L & $\mathrm{A}$ & 22 & 5.17 & 0.794 & 1.723 \\
\hline cup5 & 302 & N.pachy-L & $\mathrm{A}$ & 22 & 5.67 & 0.781 & 1.968 \\
\hline cup5 & 302 & N.pachy-L & $\mathrm{A}$ & 23 & 4.83 & 0.770 & 1.839 \\
\hline cup5 & 302 & N.pachy-L & $\mathrm{A}$ & 3 & 7.83 & 1.163 & 1.272 \\
\hline cup5 & 302 & N.pachy-L & $\mathrm{A}$ & 4 & 8.00 & 1.172 & 0.996 \\
\hline cup5 & 302 & N.pachy-L & $\mathrm{A}$ & 5 & 7.00 & 0.826 & 1.544 \\
\hline cup5 & 302 & N.pachy-L & $\mathrm{A}$ & 6 & 7.00 & 1.052 & 1.153 \\
\hline cup5 & 302 & N.pachy-L & $\mathrm{A}$ & 7 & 6.83 & 0.962 & 1.308 \\
\hline cup5 & 302 & N.pachy-L & $\mathrm{A}$ & 8 & 5.00 & 1.053 & 1.376 \\
\hline cup5 & 302 & N.pachy-L & $\mathrm{A}$ & 9 & 5.33 & 0.848 & 1.518 \\
\hline cup5 & 302 & N.pachy-L & $\mathrm{A}$ & 9 & 5.83 & 0.922 & 1.353 \\
\hline cup5 & 302 & N.pachy-L & B & 10 & 5.17 & 1.031 & 1.181 \\
\hline cup5 & 302 & N.pachy-L & $B$ & 11 & 5.50 & 1.055 & 1.318 \\
\hline cup5 & 302 & N.pachy-L & $\bar{B}$ & 12 & 5.50 & 0.995 & 1.342 \\
\hline cup5 & 302 & N.pachy-L & $\bar{B}$ & 14 & 5.83 & 0.883 & 1.435 \\
\hline cup5 & 302 & N.pachy-L & $B$ & 15 & 5.67 & 0.974 & 1.364 \\
\hline cup5 & 302 & N.pachy-L & $\mathrm{B}$ & 16 & 5.33 & 0.790 & 1.560 \\
\hline cup5 & 302 & N.pachy-L & $B$ & 17 & 5.33 & 0.899 & 1.486 \\
\hline cup5 & 302 & N.pachy-L & $B$ & 18 & 5.00 & 0.834 & 1.583 \\
\hline cup5 & 302 & N.pachy-L & $B$ & 19 & 5.50 & 0.842 & 1.548 \\
\hline cup5 & 302 & N.pachy-L & $\mathrm{B}$ & 20 & 5.50 & 0.801 & 1.665 \\
\hline cup5 & 302 & N.pachy-L & $B$ & 21 & 4.83 & 0.707 & 1.663 \\
\hline cup5 & 302 & N.pachy-L & $B$ & 21 & 5.83 & 0.804 & 1.566 \\
\hline cup5 & 302 & N.pachy-L & B & 22 & 5.33 & 0.861 & 1.629 \\
\hline cup5 & 302 & N.pachy-L & $B$ & 23 & 4.83 & 0.665 & 2.001 \\
\hline cup5 & 302 & N.pachy-L & $B$ & 3 & 7.83 & 1.047 & 1.165 \\
\hline cup5 & 302 & N.pachy-L & $B$ & 4 & 7.00 & 1.102 & 1.282 \\
\hline cup5 & 302 & N.pachy-L & $B$ & 5 & 6.67 & 1.047 & 1.086 \\
\hline cup5 & 302 & N.pachy-L & $B$ & 6 & 7.00 & 1.049 & 1.347 \\
\hline cup5 & 302 & N.pachy-L & $B$ & 7 & 6.00 & 0.870 & 1.351 \\
\hline cup5 & 302 & N.pachy-L & $B$ & 8 & 6.00 & 1.072 & 1.224 \\
\hline cup5 & 302 & N.pachy-L & $B$ & 9 & 3.83 & 0.814 & 1.500 \\
\hline cup5 & 302 & N.pachy-L & $B$ & 9 & 6.00 & 0.948 & 1.288 \\
\hline cup5 & 302 & N.pachy-L-* & $\mathrm{A}$ & 3 & 5.00 & 0.811 & 1.673 \\
\hline cup5 & 302 & N.pachy-L-* & $\mathrm{A}$ & 4 & 4.00 & 0.722 & 1.978 \\
\hline cup5 & 302 & N.pachy-L-* & $\mathrm{A}$ & 5 & 5.00 & 0.866 & 1.620 \\
\hline
\end{tabular}




\begin{tabular}{|c|c|c|c|c|c|c|c|}
\hline cup5 & 302 & N.pachy-L-* & A & 6 & 4.60 & 0.853 & 1.408 \\
\hline cup5 & 302 & N.pachy-L-* & $\mathrm{A}$ & 7 & 4.10 & 0.799 & 1.736 \\
\hline cup5 & 302 & N.pachy-L-* & B & 3 & 4.70 & 0.781 & 1.601 \\
\hline cup5 & 302 & N.pachy-L-* & $B$ & 4 & 4.20 & 0.829 & 1.757 \\
\hline cup5 & 302 & N.pachy-L-* & B & 5 & 3.60 & 0.647 & 1.659 \\
\hline cup5 & 302 & N.pachy-L-* & $\bar{B}$ & 6 & 4.50 & 0.816 & 1.686 \\
\hline cup5 & 302 & N.pachy-L-* & B & 7 & 4.50 & 0.775 & 1.652 \\
\hline cup6 & 320 & G.bulloides & $\mathrm{A}$ & 17 & 8.33 & -0.749 & 1.470 \\
\hline cup6 & 320 & G.bulloides & $\bar{B}$ & 16 & 9.00 & -0.319 & 2.215 \\
\hline cup6 & 320 & G.bulloides & $B$ & 17 & 8.33 & -0.366 & 2.109 \\
\hline cup6 & 320 & N.pachy-L & $\mathrm{A}$ & 11 & 6.33 & 0.905 & 1.456 \\
\hline cup6 & 320 & N.pachy-L & $\mathrm{A}$ & 23 & 5.33 & 0.846 & 1.595 \\
\hline cup6 & 320 & N.pachy-L & B & 10 & 6.00 & 0.770 & 1.856 \\
\hline cup6 & 320 & N.pachy-L & $B$ & 11 & 6.33 & 0.886 & 1.469 \\
\hline cup6 & 320 & N.pachy-L & B & 22 & 6.33 & 0.808 & 1.377 \\
\hline cup6 & 320 & N.pachy-L & $B$ & 23 & 4.67 & 0.680 & 1.433 \\
\hline cup7 & 337 & G.bulloides & A & 18 & 8.33 & -0.779 & 1.766 \\
\hline cup7 & 337 & G.bulloides & $\mathrm{A}$ & 19 & 8.33 & -0.677 & 1.781 \\
\hline cup7 & 337 & G.bulloides & A & 23 & 8.33 & -0.834 & 2.006 \\
\hline cup7 & 337 & G.bulloides & B & 18 & 8.00 & -0.487 & 1.864 \\
\hline cup7 & 337 & G.bulloides & B & 19 & 7.67 & -0.710 & 1.844 \\
\hline cup7 & 337 & G.bulloides & B & 23 & 8.67 & -0.607 & 1.904 \\
\hline cup7 & 337 & N.pachy-L & A & 12 & 4.67 & 0.657 & 1.717 \\
\hline cup7 & 337 & N.pachy-L & $\mathrm{A}$ & 14 & 3.83 & 0.767 & 1.551 \\
\hline cup7 & 337 & N.pachy-L & B & 12 & 5.76 & 0.718 & 1.609 \\
\hline cup8 & 354 & G.bulloides & $\mathrm{A}$ & 20 & 5.67 & -0.588 & 1.916 \\
\hline cup8 & 354 & G.bulloides & A & 21 & 11.67 & -0.601 & 2.119 \\
\hline cup8 & 354 & G.bulloides & $B$ & 20 & 10.00 & -0.549 & 2.125 \\
\hline cup8 & 354 & N.pachy-L & A & 15 & 4.50 & 0.661 & 1.850 \\
\hline cup8 & 354 & N.pachy-L & $\mathrm{B}$ & 14 & 2.50 & 0.659 & 1.864 \\
\hline cup8 & 354 & N.pachy-L & B & 15 & 3.17 & 0.649 & 1.933 \\
\hline cup9 & 7 & G.bulloides & $\mathrm{A}$ & 22 & 9.00 & -0.837 & 2.141 \\
\hline cup9 & 7 & G.bulloides & B & 21 & 10.00 & -0.687 & 2.167 \\
\hline cup9 & 7 & G.bulloides & B & 22 & 10.00 & -0.674 & 1.917 \\
\hline cup9 & 7 & N.pachy-L & A & 16 & 4.83 & 0.701 & 2.066 \\
\hline cup9 & 7 & N.pachy-L & $\mathrm{A}$ & 17 & 5.50 & 0.690 & 1.850 \\
\hline cup9 & 7 & N.pachy-L & B & 16 & 4.50 & 0.748 & 2.192 \\
\hline cup10 & 24 & G.bulloides & A & 23 & 8.33 & -0.656 & 2.302 \\
\hline cup10 & 24 & G.bulloides & $\mathrm{A}$ & 8 & 6.33 & -0.575 & 2.297 \\
\hline cup10 & 24 & G.bulloides & B & 23 & 8.33 & -0.700 & 2.101 \\
\hline cup10 & 24 & N.pachy-L & $\mathrm{A}$ & 6 & 5.67 & 0.709 & 2.206 \\
\hline cup10 & 24 & N.pachy-L & A & 7 & 5.33 & 0.575 & 2.113 \\
\hline cup10 & 24 & N.pachy-L & B & 6 & 5.33 & 0.700 & 2.241 \\
\hline
\end{tabular}




\begin{tabular}{|c|c|c|c|c|c|c|c|}
\hline cup11 & 41 & G.bulloides & $\mathrm{A}$ & 5 & 5.67 & -0.580 & 2.358 \\
\hline cup11 & 41 & G.bulloides & $B$ & 4 & 8.67 & -0.904 & 1.986 \\
\hline cup11 & 41 & G.bulloides & B & 5 & 9.00 & -0.763 & 2.363 \\
\hline cup11 & 41 & N.pachy-L & $\bar{B}$ & 7 & 5.17 & 0.662 & 2.001 \\
\hline cup12 & 59 & G.bulloides & B & 7 & 5.67 & -0.290 & 2.566 \\
\hline cup12 & 59 & G.bulloides-* & $\bar{B}$ & 16 & 3.60 & -1.080 & 2.232 \\
\hline cup12 & 59 & N.pachy-L & B & 8 & 3.83 & 0.373 & 2.175 \\
\hline cup13 & 76 & G.bulloides & $\mathrm{A}$ & 17 & 6.00 & -0.803 & 2.373 \\
\hline cup13 & 76 & N.pachy-L & $\mathrm{A}$ & 9 & 3.50 & 0.696 & 2.226 \\
\hline cup14 & 94 & G.bulloides-* & B & 17 & 3.50 & -1.240 & 2.646 \\
\hline cup14 & 94 & N.pachy-L & $\mathrm{A}$ & 8 & 2.33 & 0.368 & 2.560 \\
\hline cup14 & 94 & N.pachy-L & A & 9 & 4.17 & 0.346 & 2.751 \\
\hline cup14 & 94 & N.pachy-L & B & 8 & 4.00 & 0.307 & 2.785 \\
\hline cup15 & 111 & G.bulloides & B & 18 & 4.00 & -0.789 & 2.713 \\
\hline cup15 & 111 & N.pachy-L & A & 10 & 3.83 & 0.491 & 2.587 \\
\hline cup15 & 111 & N.pachy-L & B & 10 & 4.00 & 0.446 & 2.935 \\
\hline cup15 & 111 & N.pachy-L & $B$ & 9 & 3.50 & 0.396 & 2.699 \\
\hline cup16 & 128 & G.bulloides & $\mathrm{A}$ & 12 & 4.67 & -0.408 & 2.619 \\
\hline cup16 & 128 & G.bulloides & A & 19 & 4.67 & -0.629 & 3.184 \\
\hline cup16 & 128 & G.bulloides & $B$ & 11 & 3.33 & -0.792 & 3.127 \\
\hline cup16 & 128 & G.bulloides & $B$ & 19 & 5.33 & -0.430 & 3.230 \\
\hline cup16 & 128 & N.pachy-L & $\mathrm{A}$ & 18 & 3.83 & 0.446 & 2.863 \\
\hline cup16 & 128 & N.pachy-L & B & 17 & 5.17 & 0.549 & 2.350 \\
\hline cup16 & 128 & N.pachy-L & $B$ & 18 & 3.83 & 0.390 & 2.885 \\
\hline cup17 & 146 & G.bulloides & $\mathrm{A}$ & 14 & 3.67 & -0.165 & 2.839 \\
\hline cup17 & 146 & G.bulloides & $\mathrm{A}$ & 20 & 8.00 & -0.266 & 2.902 \\
\hline cup17 & 146 & G.bulloides & B & 12 & 5.67 & -0.206 & 2.792 \\
\hline cup17 & 146 & G.bulloides & $B$ & 14 & 7.00 & -0.206 & 2.838 \\
\hline cup17 & 146 & N.pachy-L & $\mathrm{A}$ & 19 & 2.67 & 0.389 & 2.729 \\
\hline cup17 & 146 & N.pachy-L & $\mathrm{A}$ & 20 & 3.33 & 0.377 & 2.728 \\
\hline cup17 & 146 & N.pachy-L & $B$ & 19 & 3.67 & 0.369 & 2.638 \\
\hline cup18 & 163 & G.bulloides & $\mathrm{A}$ & 15 & 8.67 & -0.549 & 2.647 \\
\hline cup18 & 163 & G.bulloides & $\mathrm{A}$ & 16 & 7.00 & -0.348 & 2.641 \\
\hline cup18 & 163 & G.bulloides & B & 15 & 8.33 & -0.279 & 2.686 \\
\hline cup18 & 163 & N.pachy-L & A & 21 & 2.67 & 0.389 & 2.541 \\
\hline cup18 & 163 & N.pachy-L & B & 20 & 3.67 & 0.304 & 2.594 \\
\hline cup18 & 163 & N.pachy-L & B & 21 & 4.33 & 0.443 & 2.635 \\
\hline cup19 & 180 & G.bulloides & $\mathrm{A}$ & 21 & 11.00 & -0.306 & 2.710 \\
\hline cup19 & 180 & G.bulloides & B & 20 & 9.33 & -0.545 & 2.695 \\
\hline cup19 & 180 & G.bulloides & B & 21 & 7.67 & -0.346 & 2.704 \\
\hline cup19 & 180 & N.pachy-L & $\mathrm{A}$ & 22 & 5.00 & 0.360 & 2.658 \\
\hline cup19 & 180 & N.pachy-L & $\mathrm{A}$ & 23 & 4.50 & 0.387 & 2.584 \\
\hline cup19 & 180 & N.pachy-L & B & 22 & 4.83 & 0.372 & 2.581 \\
\hline
\end{tabular}




\begin{tabular}{|l|r|l|l|r|r|r|r|}
\hline cup19 & 180 & N.pachy-L & B & 23 & 5.33 & 0.472 & 2.599 \\
\hline cup20 & 198 & G.bulloides & A & 22 & 9.33 & -0.303 & 2.632 \\
\hline cup20 & 198 & G.bulloides & H & 6 & 9.33 & -0.610 & 2.703 \\
\hline cup20 & 198 & N.pachy-L & A & 3 & 3.00 & 0.552 & 2.372 \\
\hline cup20 & 198 & N.pachy-L & A & 4 & 5.67 & 0.644 & 2.346 \\
\hline cup20 & 198 & N.pachy-L & B & 3 & 2.83 & 0.463 & 2.309 \\
\hline cup21 & 215 & G.bulloides & B & 22 & 7.67 & -0.266 & 2.600 \\
\hline cup21 & 215 & N.pachy-L & A & 5 & 3.33 & 0.446 & 2.597 \\
\hline cup21 & 215 & N.pachy-L & B & 4 & 3.33 & 0.564 & 2.522 \\
\hline cup21 & 215 & N.pachy-L & B & 5 & 5.17 & 0.537 & 2.437 \\
\hline
\end{tabular}




\section{Appendix C}

\begin{tabular}{|c|c|c|c|c|c|}
\hline \multicolumn{6}{|c|}{$\begin{array}{l}\text { SIZE-MORPHOMETRIC ANALYSIS } \\
\text { N. pachyderma }(\mathrm{l})\end{array}$} \\
\hline Line & $\begin{array}{l}\text { sample- } \\
\text { ID }\end{array}$ & $\begin{array}{c}\text { Avg max } \\
\text { length }(\mu \mathrm{m})\end{array}$ & $\begin{array}{l}\text { Bug weight } \\
\quad(\mu \mathrm{g})\end{array}$ & $\begin{array}{c}\delta^{13} \mathrm{C} \\
(\% \\
\text { PDB) } \\
\end{array}$ & $\begin{array}{c}\delta^{18} \mathrm{O} \\
(\% \% \\
\text { PDB) } \\
\end{array}$ \\
\hline$\overline{\mathrm{A} 3}$ & A & 298.08 & \begin{tabular}{|l|l|}
7.83 \\
\end{tabular} & 1.163 & 1.272 \\
\hline$\overline{\mathrm{B} 3}$ & B & 289.31 & 7.83 & 1.047 & 1.165 \\
\hline A4 & $\mathrm{C}$ & 283.55 & 8.00 & 1.172 & 0.996 \\
\hline $\mathrm{B} 4$ & $\mathrm{D}$ & 279.83 & 7.00 & 1.102 & 1.282 \\
\hline $\mathrm{A} 5$ & $E$ & 276.32 & 7.00 & 0.826 & 1.544 \\
\hline B5 & $F$ & 274.33 & 6.67 & 1.047 & 1.086 \\
\hline A6 & $\bar{G}$ & 271.89 & 7.00 & 1.052 & 1.153 \\
\hline B6 & $\mathrm{H}$ & 268.85 & 7.00 & 1.049 & 1.347 \\
\hline A7 & I & 266.83 & 6.83 & 0.962 & 1.308 \\
\hline B7 & $\mathrm{J}$ & 265.04 & 6.00 & 0.870 & 1.351 \\
\hline A8 & $\bar{K}$ & 263.98 & 5.00 & 1.053 & 1.376 \\
\hline B8 & $\mathrm{L}$ & 262.21 & 6.00 & $\begin{array}{l}1.072 \\
\end{array}$ & 1.224 \\
\hline A9 & $\bar{M}$ & 260.6 & \begin{tabular}{|l|}
5.83 \\
\end{tabular} & 0.922 & 1.353 \\
\hline$\overline{\mathrm{B} 9}$ & $\mathrm{~N}$ & 258.91 & 6.00 & 0.948 & 1.288 \\
\hline A10 & $\mathrm{O}$ & 257.88 & 5.50 & 0.904 & 1.530 \\
\hline $\bar{B} 10$ & $\mathrm{P}$ & 256.73 & 5.67 & 1.031 & 1.181 \\
\hline A11 & Q & 254.79 & 5.17 & 0.909 & 1.301 \\
\hline B11 & $\mathrm{R}$ & 252.92 & 5.50 & 1.055 & 1.318 \\
\hline A12 & $\mathrm{S}$ & 251.93 & \begin{tabular}{|l|}
5.83 \\
\end{tabular} & 1.022 & \begin{tabular}{|l|}
1.373 \\
\end{tabular} \\
\hline B12 & $\mathrm{T}$ & 250.89 & 5.50 & 0.995 & 1.342 \\
\hline A14 & $\bar{U}$ & 248.02 & 6.00 & 0.932 & 1.403 \\
\hline$\overline{\text { B14 }}$ & $\bar{V}$ & 246.45 & 5.83 & 0.883 & 1.435 \\
\hline A15 & $\bar{W}$ & 245.01 & 5.83 & 0.848 & 1.417 \\
\hline B15 & $\mathrm{X}$ & 243.07 & 5.67 & 0.974 & 1.364 \\
\hline A16 & $\bar{Y}$ & 241.33 & 6.00 & 0.817 & 1.525 \\
\hline B16 & $\mathrm{Z}$ & 240.11 & 5.33 & 0.790 & 1.560 \\
\hline A17 & $\mathrm{AA}$ & 239.2 & 5.33 & 0.913 & 1.684 \\
\hline B17 & $\mathrm{AB}$ & 237.78 & 5.33 & 0.899 & 1.486 \\
\hline A18 & $\mathrm{AC}$ & 236.52 & 6.17 & 0.894 & 1.517 \\
\hline $\bar{B} 18$ & $\mathrm{AD}$ & 235.86 & 5.00 & 0.834 & 1.583 \\
\hline A19 & $\overline{\mathrm{AE}}$ & 234.5 & 5.67 & 0.832 & 1.577 \\
\hline B19 & $\overline{\mathrm{AF}}$ & 232.75 & 5.50 & 0.842 & 1.548 \\
\hline $\mathrm{A} 20$ & $\overline{A G}$ & 231.34 & 5.50 & 0.872 & 1.693 \\
\hline
\end{tabular}




\begin{tabular}{|l|c|r|r|r|r|}
\hline B20 & AH & 229.59 & 5.50 & 0.801 & 1.665 \\
\hline A21 & AI & 227.54 & 5.17 & 0.789 & 1.633 \\
\hline B21 & AJ & 225.89 & 4.83 & 0.707 & 1.663 \\
\hline A22 & AK & 224.51 & 5.17 & 0.794 & 1.723 \\
\hline B22 & AL & 222.7 & 5.33 & 0.861 & 1.629 \\
\hline A23 & AM & 220.18 & 4.83 & 0.770 & 1.839 \\
\hline B23 & AN & 213.8 & 4.83 & 0.665 & 2.001 \\
\hline
\end{tabular}




\section{Appendix D}

\begin{tabular}{|c|c|c|c|c|c|}
\hline \multicolumn{6}{|c|}{$\begin{array}{l}\text { SIZE-MORPHOMETRIC ANALYSIS } \\
\text { G. bulloides }\end{array}$} \\
\hline Line & \begin{tabular}{c|} 
sample- \\
ID
\end{tabular} & $\begin{array}{c}\text { Avg max } \\
\text { length }(\mu \mathrm{m})\end{array}$ & $\begin{array}{c}\text { Bug weight } \\
(\mu \mathrm{g})\end{array}$ & $\begin{array}{c}\delta^{13} \mathrm{C} \\
(\% \circ \\
\text { PDB) } \\
\end{array}$ & $\begin{array}{c}\delta^{180} \\
\text { ( \%o } \\
\text { PDB) }\end{array}$ \\
\hline$\overline{\mathrm{A} 3}$ & $a$ & 337.28 & $\begin{array}{l}8.67 \mid \\
\end{array}$ & -0.275 & 1.686 \\
\hline B3 & $\mathrm{b}$ & 329.57 & 9.33 & -0.135 & 1.834 \\
\hline A4 & c & 324.87 & 8.00 & -0.132 & 2.066 \\
\hline B4 & $\mathrm{d}$ & 320.65 & 8.33 & -0.038 & 2.493 \\
\hline A5 & $\mathrm{e}$ & 317.11 & 7.33 & -0.119 & 2.111 \\
\hline B5 & $\mathrm{f}$ & 312.93 & 8.33 & -0.078 & 2.399 \\
\hline $\mathrm{A} 6$ & $\mathrm{~g}$ & 310.63 & 6.00 & -0.270 & 2.067 \\
\hline B6 & $\mathrm{h}$ & 308.01 & \begin{tabular}{|c|}
6.67 \\
\end{tabular} & 0.037 & 2.430 \\
\hline A7 & i & 305.93 & \begin{tabular}{|c|}
7.67 \\
\end{tabular} & -0.309 & 2.000 \\
\hline B7 & $j$ & 305.14 & 8.00 & -0.161 & 2.068 \\
\hline A8 & $\mathrm{k}$ & 303.83 & 8.00 & -0.137 & 2.205 \\
\hline B8 & 1 & 303.27 & 8.00 & -0.052 & 2.391 \\
\hline A9 & $\mathrm{m}$ & 302.1 & 7.33 & -0.228 & 2.249 \\
\hline B9 & $\mathrm{n}$ & 299.75 & 7.33 & -0.355 & 1.923 \\
\hline A10 & $\mathrm{O}$ & 297.32 & 9.00 & -0.078 & 2.399 \\
\hline $\bar{B} 10$ & p & 295.71 & 8.67 & -0.255 & 2.139 \\
\hline A11 & $\mathrm{q}$ & 295.21 & 8.33 & -0.176 & 2.153 \\
\hline B11 & $\mathrm{r}$ & 294.11 & 7.67 & 0.040 & 2.604 \\
\hline A12 & $\mathrm{s}$ & 293.14 & 9.00 & \begin{tabular}{|c|}
-0.199 \\
\end{tabular} & 2.393 \\
\hline $\mathrm{B} 12$ & $t$ & 291.8 & 10.00 & -0.074 & 2.413 \\
\hline A14 & $\mathrm{u}$ & 290.49 & 9.33 & -0.032 & 2.274 \\
\hline$\overline{B 14}$ & $\mathrm{~V}$ & 287.73 & 7.33 & -0.405 & 2.116 \\
\hline A15 & $\mathrm{W}$ & 286.07 & 8.00 & 0.035 & 2.521 \\
\hline B15 & $x$ & 284.72 & 7.33 & -0.134 & 2.364 \\
\hline A16 & $\mathrm{y}$ & 283.71 & \begin{tabular}{|c|}
6.67 \\
\end{tabular} & -0.116 & 2.221 \\
\hline B16 & $\mathrm{z}$ & 280.39 & 7.00 & -0.030 & 2.256 \\
\hline A17 & $a a$ & 278.83 & 6.00 & -0.221 & 2.339 \\
\hline B17 & $a b$ & 277.69 & 7.33 & -0.398 & 1.915 \\
\hline A18 & $\mathrm{ac}$ & 276.22 & 7.33 & -0.478 & 2.308 \\
\hline
\end{tabular}




\begin{tabular}{|l|c|r|r|r|r|}
\hline B18 & ad & 274.52 & 7.00 & -0.057 & 2.144 \\
\hline A19 & ae & 271.98 & 7.67 & -0.208 & 2.463 \\
\hline B19 & af & 270.11 & 8.67 & -0.255 & 2.252 \\
\hline A20 & ag & 268.35 & 7.67 & -0.182 & 2.188 \\
\hline B20 & ah & 266.76 & 7.67 & -0.112 & 2.390 \\
\hline A21 & ai & 261.91 & 8.00 & 0.113 & 2.721 \\
\hline B21 & aj & 260.29 & 7.00 & -0.226 & 2.261 \\
\hline A22 & ak & 258.23 & 7.33 & -0.351 & 2.556 \\
\hline B22 & al & 253.87 & 6.33 & -0.227 & 2.492 \\
\hline A23 & am & 250.08 & 8.00 & -0.330 & 2.381 \\
\hline B23 & an & 243.94 & 8.00 & -0.438 & 2.295 \\
\hline
\end{tabular}

